\title{
VARIAÇÕES NO CONSUMO DE ALIMENTOS NO BRASIL DE 1974/75 A 1987/88.
}

\section{EDSON MARTINS}

Engenheiro Agrônomo

Orientador: Prof. Dr. RODOLFO HOFFMANN

Dissertação apresentada à Escola Superior de

Agricultura "Luiz de Queiroz", Universidade de São Paulo, para obtenção do título de Mestre em Ciências, Área de concentração: Economia Aplicada.

P I R A C I C A B A

Estado de São Paulo - Brasil

Maio - 1998 
Dados Internacionais de Catalogação na Publicação (CIP) DIVISĀo dE BIBLIOTECA E DOCUMENTAÇÃO - Campus "Luiz de Queiroz"/USP

Martins, Edson

Variaçōes no consumo de alimentos no Brasil de 1974/75 a 1987/88 / Edson Martins. - Piracicaba, 1998

$117 \mathrm{p}$.

Dissertaçăo (mestrado) - Escola Superior de Agricultura Luiz de Queiroz, 1998. Bibliografia.

1. Alimentação humana 2. Aspectos politico-socio-econònico 3. Cesta básica de alimento 4. Consumo alimentar 5 . Distribuição de renda 6 . Elasticidade da renda 7. Hábito alimentar 8. Segurança alimentar I. Titulo 


\title{
VARIAÇÕES NO CONSUMO DE ALIMENTOS NO BRASIL DE 1974/75 A 1987/88.
}

\author{
EDSON MARTINS
}

Aprovada em :

Comissão julgadora:

Prof. Dr. Rodolfo Hoffmann ESALQ/USP

Prof. Dr. Joaquim Bento S. Ferreira F ${ }^{\circ}$ ESALQ/USP

Prof. Dr Elias José Simon FCA/ UNESP 
À Adriana, com amor. 


\section{Agradecimentos}

Ao Prof. Dr. Rodolfo Hoffmann por sua orientação segura e precisa.

Aos professores do curso de Economia Aplicada da ESALQ/USP que deram o embasamento necessário para a realização deste trabalho. Aos sempre atenciosos funcionários do Departamento de Economia e Sociologia Rural.

Aos professores Joaquim Bento e João Martines pelas sugestões e a professora Zilda Mattos pela atenciosa contribuição.

Aos meus pais, José e Rosa, e meus irmãos, agradeço, pelo simples fato de serem a minha família.

Um agradecimento especial à Sandra por ser, além de irmã, amiga. Ao Paulo de Tarso e ao Elias por terem me apoiado e estimulado a continuar.

Ao melhor que o Paraná podia me oferecer: Adenise, Carlos, Márcia e Ronaldo. E a todos amigos da pós, em especial o Leonardo, a Nancy e o Maurício. Ao Nohara pelo constante estímulo e amizade.

Aos amigos Ana e Henrique pelas sugestões. A Tati pelo esforço com a tradução. Aos amigos republicanos Adonis, Alexandre J., Alexandre H., Axel e Ronaldo. Ao Osho e sua turma que providencialmente surgiram em minha vida. Ao Parisi, Ivan e Luciane pela amizade sincera.

Aos amigos de sempre que não ousarei listar.

Ao CNPq pela bolsa concedida durante o curso de mestrado.

À Existência, por ser maravilhosa. 
Página

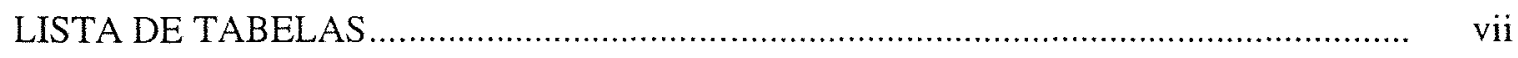

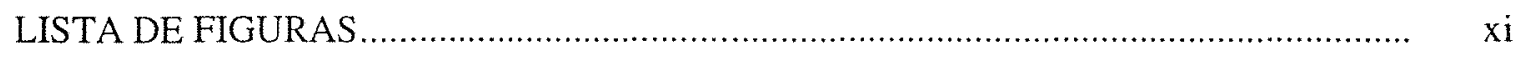

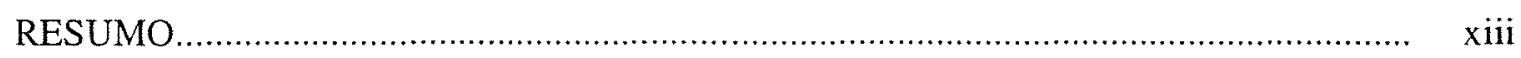

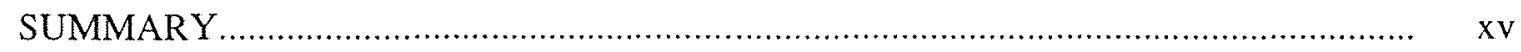

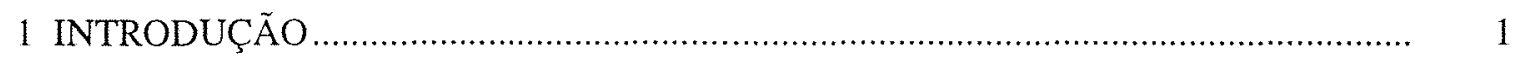

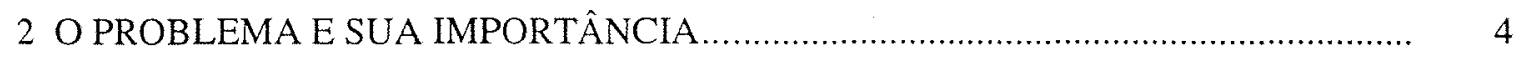

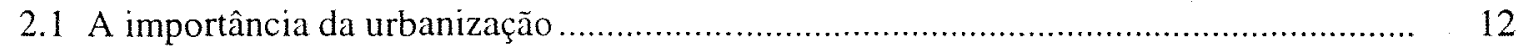

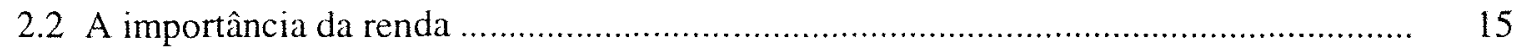

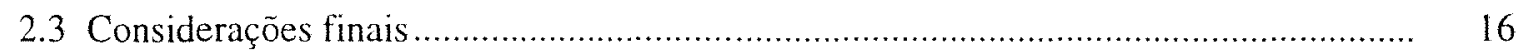

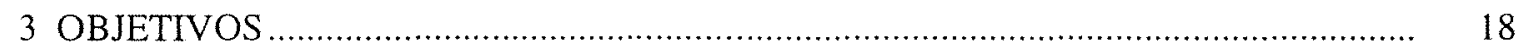

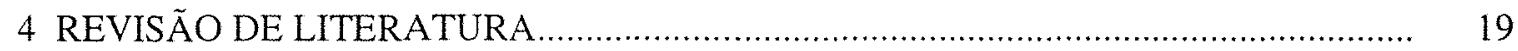

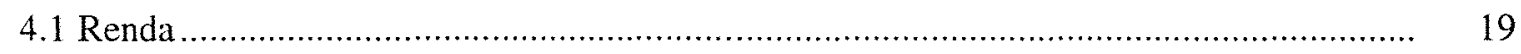

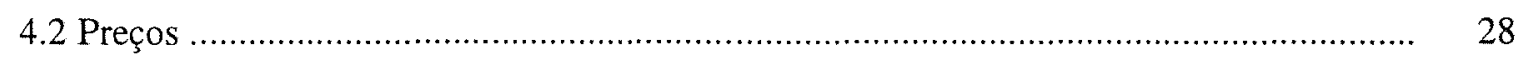

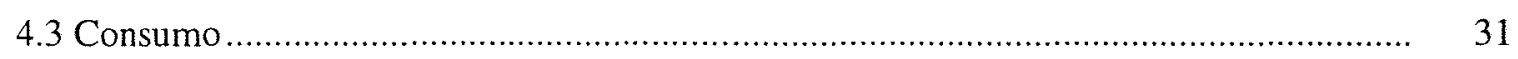

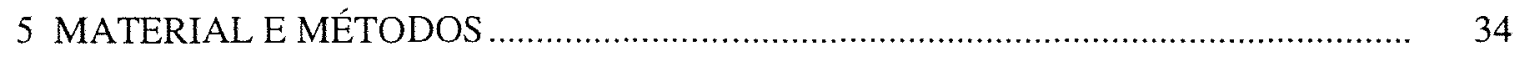

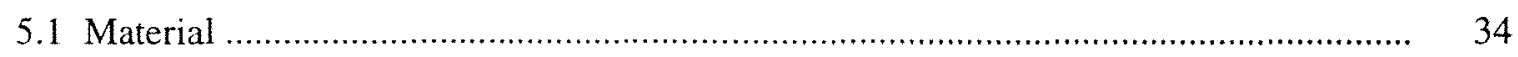

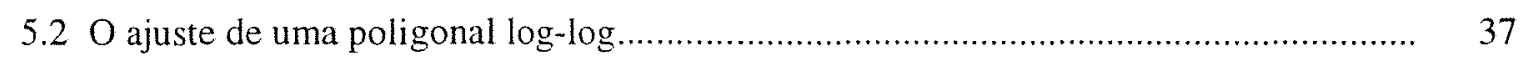

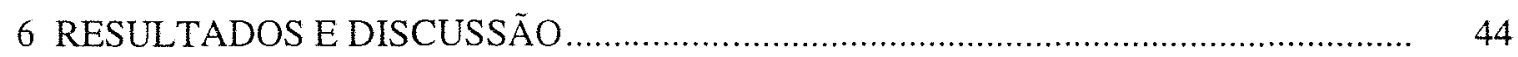

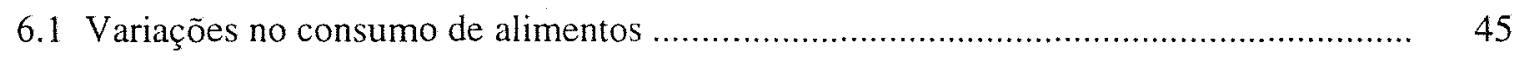

6.1.1 Variações nas quantidades físicas consumidas ........................................................... 45

6.1.2 Variações nas despesas com alimentação ............................................................... 48

6.2 Apresentação dos resultados por alimentos ou grupo de alimentos ............................. 51

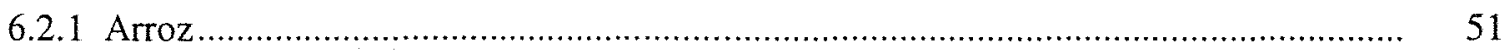

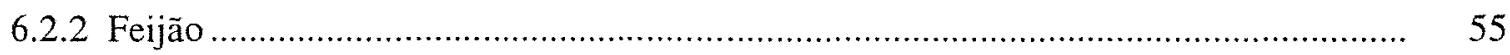

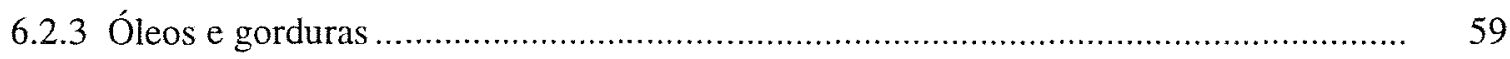

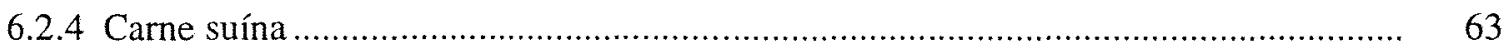

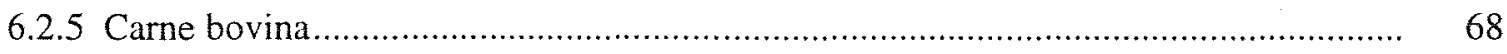

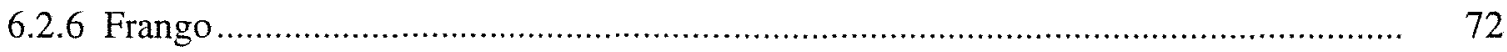

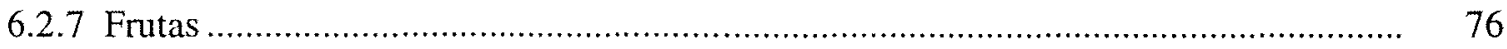

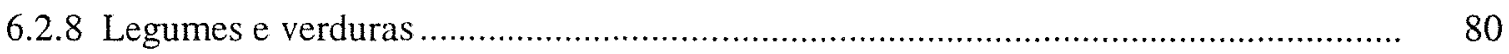


Página

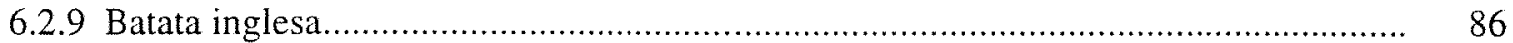

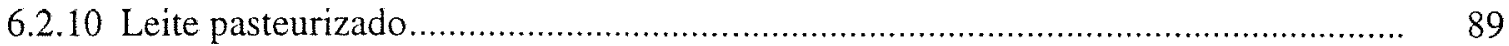

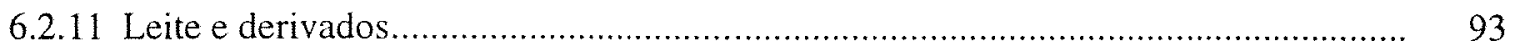

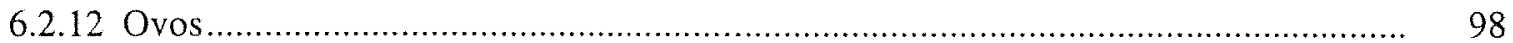

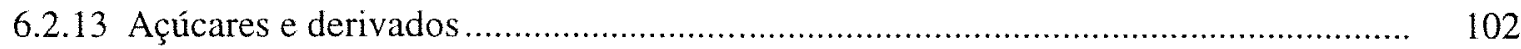

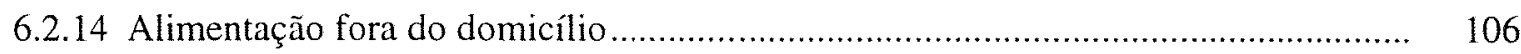

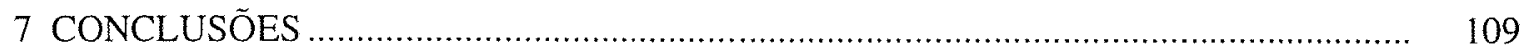

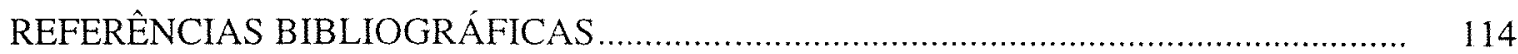




\section{LISTA DE TABELAS}

Página

1 Despesa monetária média familiar com alimentação em relação à despesa global, dentro e fora do domicilio, para 10 áreas urbanas do Brasil. Dados do ENDEF de 1974/75

2 Despesa monetária média familiar com alimentação em relação à despesa global, dentro e fora do domicílio, para 10 áreas urbanas do Brasil. Dados da POF de $1987 / 88$

3 Despesa média mensal familiar com alguns alimentos e grupos de alimentos como porcentagem do dispêndio total com alimentação dentro do domicílio, para 10 áreas urbanas. Baseado nos dados do ENDEF para 1974/75.

4 Despesa média mensal familiar com alguns alimentos e grupos de alimentos como porcentagem do dispêndio total com alimentação dentro do domicílio, para 10 áreas urbanas. Baseado nos dados da POF para 1987/88

5 Despesa monetária e não monetária per capita com grupos de alimentos, no Brasil e nas suas áreas metropolitanas, urbanas não metropolitanas, e rurais. De acordo com dados do ENDEF (1974/75)

6 Grau de urbanização da população residente no Brasil, 1940 -1991

7 Coeficientes de elasticidade-renda do dispêndio, por grupos de alimentos calculados através do ajuste de poligonal log-log. Piracicaba, 1971

8 Coeficientes de elasticidade-renda da demanda por grupos de alimentos, nos estratos considerados, para o estado de São Paulo, calculados através do ajustamento de poligonal bilogarítmica; coeficiente de determinação e teste $F$ da regressão.

9 Elasticidade-renda do dispêndio de produtos alimentares, valores médios do Brasil e inferior/superior nas classes de renda (despesa). Dados básicos do ENDEF (1974/75). 
10 Elasticidades de demanda de carne bovina calculadas nas médias amostrais para curto e longo prazos

11 Elasticidade-renda da despesa per capita com feijão em 10 áreas urbanas do Brasil, obtida com o ajustamento de uma poligonal log-log, de acordo com dados da POF

12 Estimativas da elasticidade-renda da despesa com leite e derivados para 9 regiões metropolitanas do Brasil. Dados da POF para $1987 / 88$

13 Dispêndio mensal per capita com os vários grupos de alimentos. Botucatu, 1978 (cruzeiros de 1978)

14 Número de domicílios pesquisados, estimativa da população urbana metropolitana e do número de famílias abrangidas pela POF - 87/88 nas 11 áreas urbanas

15 Classes de recebimento mensal familiar em pisos salariais e em cruzados de outubro de 1987

16 Consumo médio anual de alimentos em 10 áreas urbanas do Brasil. Por comensal-dia no ENDEF (1974/75) e per capita na POF (1987/88)....

17 Despesa média anual per capita com alimentação em 10 áreas urbanas do Brasil, segundo os dados do ENDEF e da POF. Valores em Cruzados deflacionados pela combinação dos índices INPC e Índice Geral de Preços ao Consumidor (Cruzados de março de 1986)

18 Coeficientes de Elasticidade-renda da despesa per capita com arroz nos estratos considerados para 10 áreas urbanas do Brasil, obtidos através do ajustamento de uma poligonal log-log de acordo com dados da POF(198788)

19 Coeficientes de Elasticidade-renda da despesa per capita com feijão nos estratos considerados para 10 áreas urbanas do Brasil, obtidos através do 
ajustamento de uma poligonal log-log de acordo com dados da POF(198788)

20 Coeficientes de Elasticidade-renda da despesa per capita com óleos e gorduras nos estratos considerados para 11 áreas urbanas do Brasil, obtidos através do ajustamento de uma poligonal log-log de acordo com dados da POF (1987-88)

21 Coeficientes de Elasticidade-renda da despesa per capita com carne suína nos estratos considerados para 11 áreas urbanas do Brasil, obtidos através do ajustamento de uma poligonal log-log de acordo com dados da POF(1987-88)

22 Coeficientes de Elasticidade-renda da despesa per capita com carne bovina nos estratos considerados para 11 áreas urbanas do Brasil, obtidos através do ajustamento de uma poligonal $\log -\log$ de acordo com dados da POF $(1987-88)$

23 Coeficientes de Elasticidade-renda da despesa per capita com frango nos estratos considerados para 10 áreas urbanas do Brasil, obtidos através do ajustamento de uma poligonal log-log de cordo com dados da POF (198788)

24 Coeficientes de Elasticidade-renda da despesa per capita com frutas nos estratos considerados para 10 áreas urbanas do Brasil, obtidos através do ajustamento de uma poligonal log-log de acordo com dados da POF (198788)

25 Coeficientes de Elasticidade-renda da despesa per capita com legumes e verduras nos estratos considerados para 11 áreas urbanas do Brasil, obtidos através do ajustamento de uma poligonal log-log de acordo com dados da POF (1987-88)

26 Coeficientes de Elasticidade-renda da despesa per capita com batata inglesa nos estratos considerados para 11 áreas urbanas do Brasil, obtidos através 
do ajustamento de uma poligonal log-log de acordo com dados da POF $(1987-88)$

27 Coeficientes de Elasticidade-renda da despesa per capita com leite pasteurizado nos estratos considerados para 11 áreas urbanas do Brasil, obtidos através do ajustamento de uma poligonal log-log de acordo com dados da POF (1987-88)

28 Coeficientes de Elasticidade-renda da despesa per capita com leite e derivados nos estratos considerados para 11 áreas urbanas do Brasil, obtidos através do ajustamento de uma poligonal log-log de acordo com dados da POF (1987-88)

29 Coeficientes de Elasticidade-renda da despesa per capita com ovos nos estratos considerados para 11 áreas urbanas do Brasil, obtidos através do ajustamento de uma poligonal log-log de acordo com dados da POF (198788)

30 Coeficientes de Elasticidade-renda da despesa per capita com açúcares e derivados nos estratos considerados para 10 áreas urbanas do Brasil, obtidos através do ajustamento de uma poligonal log-log de acordo com dados da POF (1987-88)

31 Coeficientes de Elasticidade-renda da despesa per capita com alimentação fora do domicílio nos estratos considerados para 11 áreas urbanas do Brasil, obtidos através do ajustamento de uma poligonal log-log de acordo com dados daPOF (1987-88) 


\section{LISTA DE FIGURAS}

Página

1 Índice do PIB per capita no Brasil, 1970/90.

2 Preços médios anuais do arroz $(\mathrm{kg})$ no varejo da cidade de São Paulo 1974/88. Em cruzados de março 1986

3 Preços médios anuais do feijão $(\mathrm{kg})$ no varejo da cidade de São Paulo 1974/88. Em cruzados de março 1986

4 Preços médios anuais dos óleos de soja, arroz e algodão (lata de $900 \mathrm{ml}$ ) no varejo da cidade de São Paulo - 1974/88. Em cruzados de março 1986.

5 Preços médios anuais das carnes suína, bovina e de frango $(\mathrm{kg})$ no varejo da cidade de São Paulo -1974/88. Em cruzadosde março1986

6 Preços médios anuais da banana-nanica $(\mathrm{dz})$ no varejo da cidade de São Paulo - 1974/88. Em cruzados de março 1986

7 Preços médios anuais da laranja $(\mathrm{dz})$ no varejo da cidade de São Paulo 1974/88. Em cruzados de março 1986

8 Preços médios anuais do alface (pé) no varejo da cidade de São Paulo 1974/88. Em cruzados de março 1986

9 Preços médios anuais da cebola $(\mathrm{kg})$ no varejo da cidade de São Paulo 1974/88. Em cruzados de março 1986

10 Preços médios anuais do tomate de mesa $(\mathrm{kg})$ no varejo da cidade de São Paulo - 1974/88. Em cruzados de março 1986.

11 Preços médios anuais da batata inglesa $(\mathrm{kg})$ no varejo da cidade de SãoPaulo - 1974/88. Em cruzados de março 1986.

12 Preços médios anuais do leite tipo $\mathrm{B}$ e tipo $\mathrm{C}$ (1) no varejo da cidade de SãoPaulo - 1974/88. Em cruzados de março 1986 
13 Preços médios anuais do leite em pó $(\mathrm{kg})$ no varejo da cidade de São Paulo1974/88. Em cruzados de março 1986

14 Preços médios anuais do queijo-tipo minas $(\mathrm{kg})$ no varejo da cidade de SãoPaulo - 1974/88. Em cruzados de março 1986

15 Preços médios anuais do queijo-tipo prato $(\mathrm{kg})$ no varejo da cidade de SãoPaulo - 1974/88. Em cruzados de março 1986

16 Preços médios anuais do ovo $(\mathrm{kg})$ no varejo da cidade de São Paulo 1974/88. Em cruzados de março 1986

17 Preços médios anuais do açúcar $(\mathrm{kg})$ no varejo da cidade de São Paulo 1974/88. Em cruzados de março 1986 


\title{
VARIAÇÕES NO CONSUMO DE ALIMENTOS NO BRASIL DE 1974/75 A 1987/88.
}

\author{
Autor: EDSON MARTINS \\ Orientador: Prof. Dr. RODOLFO HOFFMANN
}

\section{RESUMO}

O objetivo desta pesquisa foi estudar as mudanças na dieta dos brasileiros entre os anos de 1974/75 e 1987/88, analisando as variações no consumo dos principais alimentos da cesta básica. As variações nas quantidades consumidas per capita de cada alimento foram obtidas a partir da comparação dos dados de duas pesquisas de orçamentos familiares realizadas pelo IBGE: o ENDEF (1974/75) e a POF (1987/88). Os dados utilizados são as despesas monetárias com alimentação nas dez principais áreas urbanas do país. As mudanças observadas no padrão alimentar foram explicadas com base na evolução dos preços reais e no efeito da renda projetado pelos coeficientes de elasticidade-renda do dispêndio com cada alimento. Os coeficientes de elasticidaderenda foram obtidos a partir do ajustamento de uma poligonal log-log aos dados de dispêndio com cada alimento ou grupo de alimentos, utilizando-se para isso o método de mínimos quadrados ponderados. Os dados utilizados para estimar estes coeficientes são da POF e referem-se às onze principais áreas urbanas do país.

De forma geral pôde-se constatar que as principais refeições dos brasileiros, almoço e jantar, tiveram a sua composição alterada. Os cereais estão cedendo lugar para alimentos mais ricos nutricionalmente e com maior praticidade no preparo. Observou-se, para o conjunto dos produtos abordados neste estudo, uma elevação de $15,13 \mathrm{~kg}$ no seu consumo per capita médio anual, embora o total das despesas com esses produtos tenha se reduzido em $5 \%$. A participação das despesas com alimentação fora do domicílio no 
total das despesas com alimentação aumentou para $25 \%$, contribuindo para reduzir o tempo médio gasto para preparar as refeições.

Notou-se redução no consumo médio per capita de arroz, feijão, batata inglesa, tomate, alface, leite não pasteurizado, leite em pó, açúcar, pão francês e macarrão. Os principais produtos que apresentaram elevação em seu consumo médio per capita foram: leite pasteurizado, carne de frango, frutas, queijos, cebola e ovos. No caso de óleos e gorduras, carne suína e carne bovina as variações nas quantidades ingeridas per capita foram pequenas.

Os coeficientes de elasticidade-renda do dispêndio com cereais e carnes para os estratos de menor renda são maiores do que aqueles obtidos para estratos de renda superiores. O mesmo ocorreu com os coeficientes obtidos para o dispêndio com alimentação fora do domicílio. Para os demais produtos pôde-se observar, em algumas das áreas urbanas estudadas, coeficientes maiores nos estratos de renda média do que nos estratos de menor renda.

Os coeficientes de elasticidade-renda para os alimentos básicos apresentaram valores que variaram entre zero e 0,5 . Portanto, sob o efeito de uma eventual elevação na renda per capita da população, sem que ocorra uma redistribuição nessa renda, a elevação no consumo desses alimentos será pequena. 


\title{
FOOD CONSUMPTION VARIATIONS IN BRAZIL BETWEEN 1974/75 AND 1987/88
}

\author{
Author: EDSON MARTINS \\ Adviser: Prof. Dr. RODOLFO HOFFMANN
}

\section{SUMMARY}

The objective of this research was to study the changes in Brazilians' diet, between $1974 / 75$ and $1987 / 88$, by analysing variations of the main components of the minimum standard diet.

Variations in quantity consumed per capita of each food were obtained by comparing data from two family budget surveys carried out by IBGE: ENDEF (1974/75) and POF (1987/88). The data used refer to expenses with food in the capitals of the main states of the country. The observed changes in standard diet were explained considering real prices' evolution and income effect projected by income elasticity coefficients of the expenditures on each food.

The income elasticity coefficients were obtained by estimating a log-log polygonal function using data of expenditures on each food or group of food, using weighted least squares method.

In general, it could be concluded that that the composition of the main Brazilians' meals, lunch and dinner, has changed in the analysed period. Nutritionally richer and easier to prepare foods are being substituted for cereals. There was an increase of $15,13 \mathrm{~kg}$ in the annual average per capita consumption of the analysed food products, although their total cost has been reduced by $5 \%$. The participation of 
expenses on eating outside home in total food expenses increased by $25 \%$, contributing to reduce average time spent on meals' preparation.

There was a reduction in the average per capita consumption of rice, beans, potato, tomato, lettuce, non pasteurized milk, powder milk, sugar, French bread and pasta. The main products that presented an increase in their average per capita consumption were: pasteurized milk, poultry, fruits, cheese, onion and eggs. There was a small variation in the per capita consumption of oil, fat, pork and beef.

The income-elasticity coefficients of the expenses on cereals and meat for low-income classes are larger than the ones obtained for high-income classes. The same has occurred with the coefficients obtained for expenses on eating outside home. For the remaining food items, it could be observed that for some of the studied urban areas, income-elasticity coefficients were larger for medium-income than for low-income classes.

The income-elasticity coefficients for basic food products varied from zero to 0,5. Therefore, the effect of a possible increase in the per capita income of the population on the consumption of these basic products will be small. 


\section{INTRODUÇÃO}

O consumo de alimentos, bem como o consumo de outros bens, é determinado por fatores econômicos, sociais, culturais e, também, pelas suas inter-relações. Nos fatores econômicos estão incluídos os preços dos alimentos e os preços dos bens complementares e substitutos, o nivel da renda da população e a sua distribuição, a quantidade de mercadoria ofertada, etc. Os fatores sociais são representados pela escolaridade, grau de urbanização da população, condições de higiene, saneamento, moradia, atendimento de profissionais das áreas de saúde e nutrição, dentre outros. Os fatores culturais são aqueles encontrados nos padrões de conduta intrínsecos a determinados povos, regiões, grupos familiares etc. São transmitidos de geração em geração e estão sujeitos a diversos tipos de influencias, modismos, valores morais e religiosos etc.

A oferta de um bem ou serviço, em termos econômicos, é a função que mostra como varia a quantidade disponivel de um produto em relação ao seu preço em determinado mercado. Vários fatores afetam a oferta dos produtos: a tecnologia, o clima, os preços dos insumos, etc. Se, por exemplo, o preço de determinado insumo se elevar, a oferta vai se deslocar para a esquerda. No curto prazo, os preços dos produtos agrícolas variam mais do que os preços dos bens industriais, devido às características próprias da produção agropecuária, especialmente o caráter estacional da produção (Hoffmann, 1970). A função demanda, por sua vez, mostra como o consumo de determinado produto varia em relação ao seu preço. São inúmeros os fatores que podem afetar a demanda de alimentos, porém a renda é o seu principal fator limitante. Para indivíduos de baixo poder aquisitivo, um acréscimo na renda permite o acesso a alimentação mais adequada, em termos quantitativos e qualitativos. Entre 1970 e 1990 a renda per capita no Brasil 
aumentou substancialmente, mas o grau de desigualdade da distribuição da renda se manteve elevado. Os dados apresentados pela Pesquisa Nacional por Amostra de Domicílios - PNAD (IBGE, 1997b) referentes ao ano de 1996 mostram que a parcela que contém $70 \%$ da população de 10 anos ou mais de idade, em ordem crescente de rendimentos, fica com apenas $25,7 \%$ do total de rendimentos mensais dos brasileiros, enquanto os $30 \%$ restantes ficam com a maior parte dos rendimentos, $74,3 \%$.

Hoffmann (1995a), discutindo a questão da segurança alimentar, destaca a importância da renda ao afirmar que "...o problema da fome no Brasil não se deve à pouca disponibilidade global de alimentos, mas sim à pobreza de grande parte da população". Furtuoso (1981) estudando essa questão mostrou que a redistribuição da renda seria capaz de melhorar o estado nutricional da população de baixo poder aquisitivo.

Ao mudar para estratos de renda mais elevados, os indivíduos tendem a adquirir novos hábitos alimentares. Segundo Pinazza \& Araujo (1993), o aumento da renda faz com que a participação de cereais nas dietas diminua e o consumo de produtos com maior teor protéico, como as carnes, aumente.

As mudanças sociais também afetam os hábitos alimentares. Nas últimas décadas grande parte da população brasileira se urbanizou, causando importantes mudanças sociais. Segundo Pinazza \& Araujo (1993, p.111) a urbanização altera os hábitos alimentares “... pois aumenta o custo de oportunidade das mulheres, a propaganda e as promoções exercem grande influência no hábito alimentar, e o estilo de vida é outro". E, dessa forma, a dieta pode ser substancialmente transformada pois "...a demanda de alimentos desloca-se de produtos básicos (sorgo, milheto, milho, raízes e tubérculos, dentre outros) para cereais (arroz e trigo), frutas, alimentos de origem animal, açúcar e produtos processados".

Este estudo pretende determinar as mudanças mais importantes que ocorreram na dieta dos brasileiros entre 1974/75 e 1987/88. Para isso serão mensuradas as variações 
no consumo dos principais alimentos da cesta básica. As mudanças serão explicadas com base no efeito da renda, dos preços ou por mudanças nos hábitos.

Os resultados obtidos nesse estudo poderão ser utilizados para o aprofundamento das questões relativas às políticas de segurança alimentar, de planejamento da produção e para demais agentes econômicos do complexo alimentar. 


\section{O PROBLEMA E SUA IMPORTÂNCIA}

Neste Capítulo serão apresentadas algumas características das despesas com o consumo de alimentos no Brasil em 1974/75 e 1987/88 e a importância de alguns fatores, como a renda e a urbanização da população, na determinação dos padrões de consumo. Neste Capítulo não pretende-se fazer uma análise pormenorizada dessas questões, mas sim expor algumas questões referentes ao consumo de alimentos para que os objetivos deste trabalho possam ser apresentados.

Os dados obtidos no Estudo Nacional da Pesquisa Familiar - ENDEF (IBGE, 1978a) foram coletados entre agosto de 1974 e agosto de 1975 e mostram que nas dez regiões metropolitanas pesquisadas, os gastos realizados com alimentação fora do domicílio representavam, em média, 2,52\% da despesa monetária global (ver Tabela 1). O total das despesas com alimentos constituía 20,02\%, em média, das despesas monetárias globais desses brasileiros. As áreas metropolitanas de Belém, Fortaleza e Recife foram as que mais contribuíram para elevar o valor médio das despesas em alimentação como porcentagem da despesa global. Belém e Recife também apresentaram os menores gastos com alimentação fora do domicílio.

Cerca de doze anos após o ENDEF foi realizado outro levantamento pelo IBGE, a Pesquisa de Orçamentos Familiares - 87/88 (IBGE, 1991, n.1). Durante os meses de março de 1987 a fevereiro de 1988 foram levantados os dados do consumo alimentar em onze áreas urbanas do Brasil. Com base nesses dados construiu-se a Tabela 2 , onde são apresentados os gastos com alimentação realizados dentro e fora do domicílio como proporção da despesa global para dez dessas áreas. A média ponderada da participação das despesas totais com alimentação diminuiu 3,8\% em relação ao 
ENDEF, atingindo 19,26\% das despesas globais. As áreas urbanas de Belém, Fortaleza e Recife diminuíram suas participações nas despesas com alimentação em relação às despesas globais, atingindo valores mais próximos da média ponderada. As despesas com alimentação fora do domicilio, que representavam 13\% do total das despesas com alimentação em 1974/75, se elevaram para $25 \%$ em 1987/88. Salvador foi a área urbana com maior proporção de gastos com alimentação fora do domicílio.

Tabela 1 - Despesa monetária média familiar com alimentação em relação à despesa global ${ }^{1}$, dentro e fora do domicilio, para 10 áreas urbanas do Brasil. Dados do ENDEF $1974 / 75$.

\begin{tabular}{lccc}
\hline & \multicolumn{3}{c}{ Despesas com alimentação como porcentagem da despesa global } \\
\cline { 2 - 4 } Região Metropolitana & No domicilio & Fora do domicilio & Total \\
\hline Rio de Janeiro & 17,89 & 3,54 & 21,43 \\
São Paulo & 13,62 & 2,35 & 15,97 \\
Curitiba & 15,52 & 1,76 & 17,28 \\
Porto Alegre & 16,94 & 2,34 & 19,28 \\
Fortaleza & 26,79 & 2,22 & 29,01 \\
Recife & 25,57 & 1,69 & 27,26 \\
Salvador & 19,01 & 1,90 & 20,91 \\
Belo Horizonte & 15,04 & 1,77 & 16,81 \\
Brasilia & 17,80 & 2,47 & 20,27 \\
Belém & 29,56 & 1,36 & 30,92 \\
Média ponderada & 17,50 & 2,52 & 20,02 \\
\hline
\end{tabular}

Fonte: IBGE (1978a).

${ }^{1}$ A Despesa global inclui as despesas correntes de consumo, o aumento do ativo e a diminuição do passivo.

Vale ressaltar que a POF, ao contrário do ENDEF, não informa os valores das despesas não monetárias, que "...correspondem a tudo que houver sido produzido, pescado, caçado, coletado ou recebido em bens (troca, doação, retirada do negócio e salários em bens) e que, pelo menos na última transação não tenha passado pelo mercado" (IBGE, 1978a, p.16). Portanto, para que os dados das duas pesquisas 
pudessem ser comparados utilizou-se, somente, os valores das despesas monetárias com alimentação que se referem, especificamente, aos gastos realizados em dinheiro.

Tabela 2 - Despesa monetária média familiar com alimentação em relação à despesa global ${ }^{1}$, dentro e fora do domicilio, para 10 áreas urbanas do Brasil. Dados da POF $1987 / 88$.

\begin{tabular}{lccc}
\hline & \multicolumn{3}{c}{ Despesas com alimentação como porcentagem da despesa global } \\
\cline { 2 - 4 } Região Metropolitana & No domicilio & Fora do domicílio & Total \\
\hline Rio de Janeiro & 15,42 & 5,43 & 20,85 \\
São Paulo & 13,70 & 4,08 & 17,78 \\
Curitiba & 12,02 & 3,38 & 15,40 \\
Porto Alegre & 14,00 & 3,89 & 17,89 \\
Fortaleza & 16,83 & 5,80 & 22,63 \\
Recife & 17,83 & 5,72 & 23,55 \\
Salvador & 15,30 & 6,17 & 21,47 \\
Belo Horizonte & 14,56 & 4,96 & 19,52 \\
Brasília & 9,61 & 4,44 & 14,05 \\
Belém & 16,71 & 4,94 & 21,65 \\
Média ponderada & 14,52 & 4,74 & 19,26 \\
\hline
\end{tabular}

Fonte: POF - 87/88 (IBGE, 1991, n.1).

${ }^{\prime}$ A Despesa global inclui as despesas correntes de consumo, o aumento do ativo e a diminuição do passivo.

De acordo com os primeiros resultados divulgados pela POF do período de 1995/96 (IBGE, 1997) a proporção das despesas com alimentação em relação às despesas globais diminuiram para $16,53 \%$, sendo que as despesas com alimentação fora do domicílio representaram $25,28 \%$ do total das despesas com alimentação.

Os dados apresentados acima mostram que cada área urbana tem uma característica peçuliar de consumo. Mas, de forma geral, estão evoluindo na mesma direção, reduzindo o peso da alimentação nas despesas e aumentando a proporção das despesas com alimentação fora do domicílio. Para uma avaliação mais detalhada das questões levantadas acima, seria conveniente lançar mão de dados de despesa com 
alimentação estratificados por classes de renda. Em virtude da indisponibilidade desses $\operatorname{dados}^{1}$ foi possível proceder, de forma pormenorizada, apenas a comparação das despesas monetárias correntes nas diversas classes de renda.

O ENDEF classifica as famílias conforme suas despesas monetárias correntes mensais. Para as famílias da classe de despesa monetária corrente de até dois salários mínimos, o menor valor encontrado para a proporção das despesas monetárias com alimentação em relação as despesas monetária correntes foi de $42,75 \%$, na região metropolitana de São Paulo, o maior valor foi de 56,39\%, em Fortaleza. Para o estrato de despesa monetária corrente superior a sete salários mínimos, o menor valor encontrado fó $16,75 \%$ e o maior $23,37 \%$, nas regiões metropolitanas de Belo Horizonte e Fortaleza, respectivamente.

$\mathrm{Na} \mathrm{POF}$ as famílias são classificadas com base no recebimento mensal. Para as famílias do estrato de menor renda, até dois salários mínimos, o menor valor encontrado para a proporção das despesas com alimentação em relação às suas despesas monetárias correntes foi de $28,18 \%$, na região metropolitana de Brasília, e a maior foi de $51,04 \%$, na região metropolitana de Fortaleza. No estrato de maior renda, mais de trinta salários mínimos, a menor participação foi de $11,64 \%$ e a maior $16,40 \%$, nas regiões metropolitanas de Curitiba e Recife, respectivamente.

Como se pode notar, são grandes as variações entre os estratos e entre as regiões metropolitanas, na participação das despesas com alimentação em relação às despesas globais. E, no intervalo de doze anos que separa as duas pesquisas, houve uma tendência de diminuição desse valor. Cabe ressalvar que essa comparação entre os dados do ENDEF e da POF apresenta limitações, pois o primeiro classifica as famílias de acordo com suas despesas monetárias correntes mensais e o segundo através do seu recebimento mensal. No entanto, nas classes de baixo rendimento, quase a totalidade do

1 O ENDEF, ao contrário da POF, não apresenta as despesas monetárias globais estratificadas por classes de renda. 
recebimento mensal é direcionado para as despesas correntes e somente uma pequena parte desse recebimento é utilizado para aumento do ativo.

A partir dos dados disponíveis no ENDEF construiu-se a Tabela 3, que apresenta a porcentagem das despesas monetárias com alguns produtos da cesta de alimentos do brasileiro em relação à despesa monetária total com alimentação dentro do domicílio, para dez regiões metropolitanas em 1974/75. Alguns produtos foram apresentados individualizados, como o arroz, carne bovina, carne suína, frango etc., e os demais na forma agregada como, por exemplo, leite e derivados que inclue queijos, iogurtes, ricota etc.. A agregação desses itens fornece uma representação, embora incompleta, da constituição da cesta de alimentos do brasileiro na época, pois representa $87,65 \%$ do total das despesas em alimentação das principais regiões metropolitanas do país.

A Tabela 4, obtida dos dados disponíveis na POF, foi construída da mesma forma que a tabela anterior e representa os anos de 1987/88. A média ponderada total mostra que diminuiu a participação desta cesta de alimentos no total das despesas com alimentação.

Comparando as Tabelas 3 e 4 observa-se que apenas 5 dos 19 itens listados aumentaram a sua participação, em valor médio, no total das despesas com alimentação no domicílio. São eles: leite e derivados, cuja participação passou de $8,62 \%$ para $15,55 \%$, açúcares e derivados de $3,26 \%$ para $5,89 \%$, frutas de $4,62 \%$ para $7,08 \%$, farinha de trigo de $0,39 \%$ para $0,48 \%$ e panificados de $7,14 \%$ para $9,16 \%$.

Dos ítens que apresentaram decréscimos na participação do total de despesas no domicílio destacam-se: óleos e gorduras, com diminuição de 6,94\% para 2,14\%, legumes e verduras de $6,91 \%$ para $3,31 \%$, arroz de $8,39 \%$ para $4,21 \%$, feijão de $4,37 \%$ para $2,54 \%$ e carne bovina de $17,81 \%$ para $14,36 \%$. 


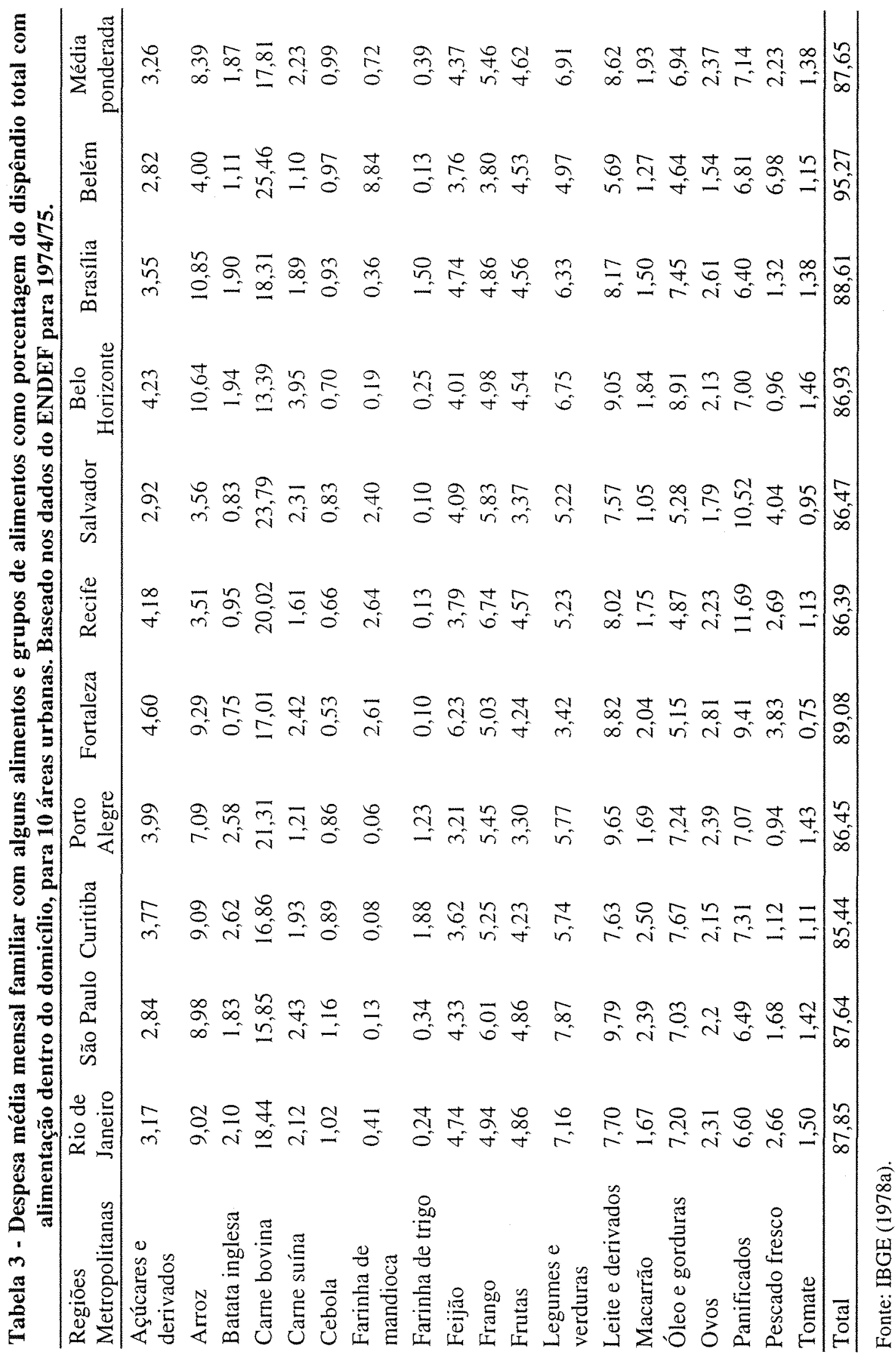




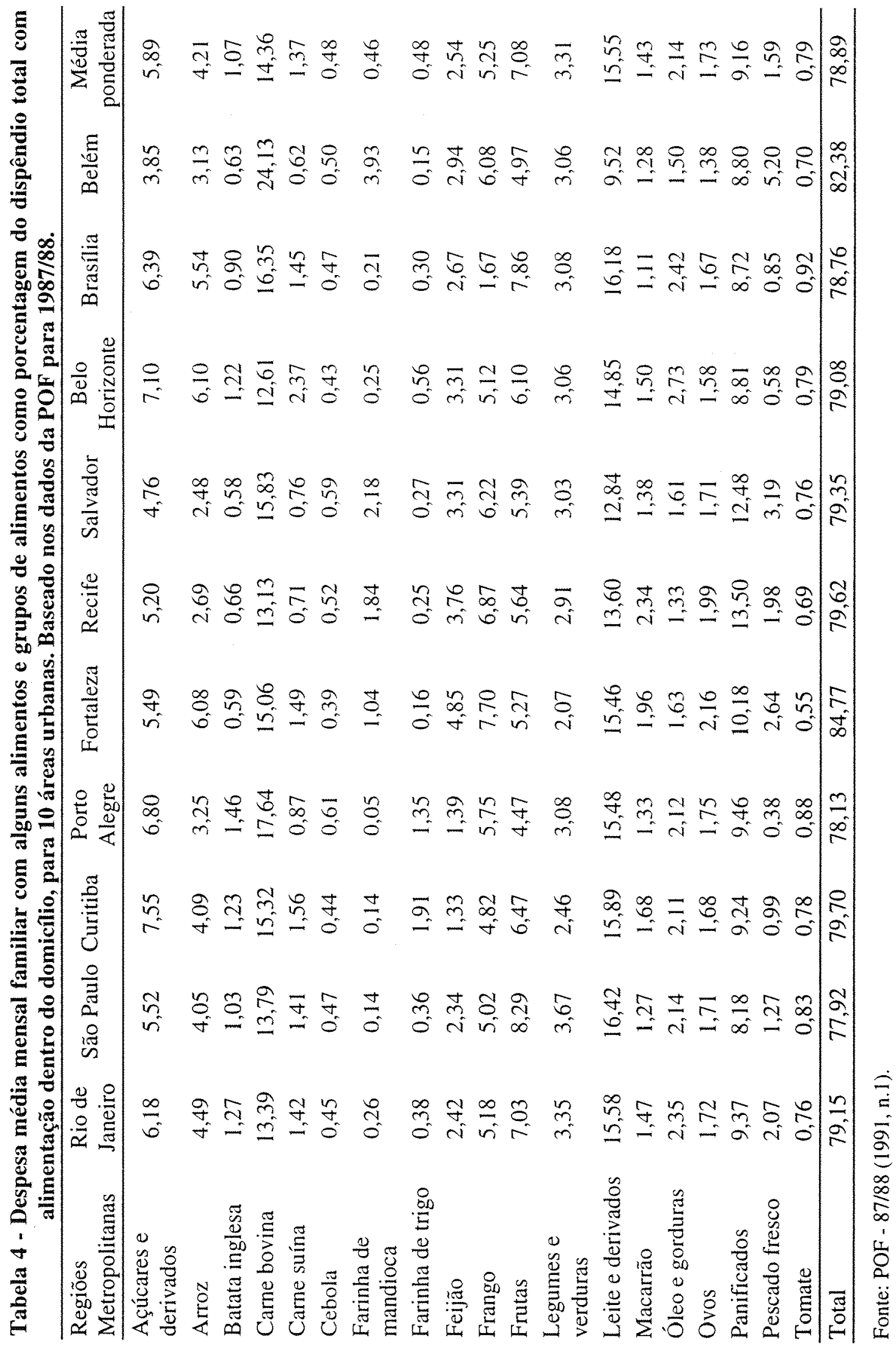


Comparando as diversas áreas urbanas apresentadas, nota-se que apesar da grande extensão territorial do país o padrão alimentar não apresenta grandes variações. Está baseado, em todas as regiões, no consumo de poucos produtos. Em 1974/75 as despesas com os onze principais produtos da cesta de alimentos representavam $75,9 \%$ do total das despesas com alimentação. Doze anos depois, a participação desses mesmos produtos no total das despesas com alimentação caiu para 71,2\%.

Em termos de diferenças regionais, nota-se que as despesas com o consumo de arroz em Recife, Salvador e Belém são menores do que no restante do país. O menor consumo de arroz nessas regiões parece ser compensado por um maior consumo de farinha de mandioca e panificados. Nota-se também que as despesas com o consumo de carne bovina e de pescado fresco nestas áreas urbanas são relativamente mais elevadas do que nas demais.

Curitiba e Porto Alegre se destacam pelas elevadas despesas com o consumo de batata inglesa e farinha de trigo, evidenciando, nessas áreas, a importância da colonização européia. Também nota-se nessas áreas urbanas as menores despesas com farinha de mandioca.

Com base nesses dados pode-se notar que, apesar da grande extensão territorial do país e da existência de diferentes padrões culinários nas suas diversas regiões, não são grandes as diferenças no padrão de consumo de alimentos do brasileiro. $\mathrm{E}$, de forma geral, as despesas com o consumo de alimentos têm se reduzido em relação ao total de despesas das famílias, e as despesas com alimentação fora do domicílio têm ganhado mais importância.

Nos ítens seguintes será analisado de forma sucinta como a urbanização e a renda podem afetar o consumo de alimentos. 


\subsection{A importância da urbanização.}

Os efeitos do processo de urbanização manifestam-se, dentre outras formas, nas novas demandas que os migrantes passam a exercer sobre a sociedade. Nos aglomerados urbanos, a alimentação apresenta características distintas daquelas encontradas no meio rural. Enquanto nos centros urbanos o trabalho é, normalmente, sedentário, no meio rural ele envolve esforço físico, exigindo uma alimentação compatível, com maior aporte de calorias, líquidos etc. Destaca-se também o fato de que no meio rural a produção para o autoconsumo supre parte das necessidades alimentares, ao passo que nas áreas urbanas a obtenção de alimentos envolve, predominantemente, transações comerciais.

Sendo assim, ao migrarem para os centros urbanos os indivíduos tenderão a substituir parte de seus hábitos alimentares por aqueles característicos dessas áreas. $\mathrm{O}$ tempo necessário para que a adoção dos novos hábitos se efetive é variável e está relacionado com fatores sócio-econômicos como a renda, os preços dos alimentos etc.

A Tabela 5 apresenta a despesa monetária e não monetária anual per capita em alimentação para as áreas metropolitanas, urbanas (não metropolitanas) e rurais, em 1974/75. Estes valores foram obtidos a partir do agrupamento das nove classes de despesas correntes das famílias, apresentadas no ENDEF, em três estratos: menos de 5 salários mínimos, de 5 a menos de 10 salários mínimos e de 10 ou mais salários mínimos. Essa forma de agrupamento foi escolhida porque no estrato de até 5 salários mínimos encontra-se $89 \%$ da população rural e grande parte da população urbana. Também é apresentada a média ponderada de cada área. 


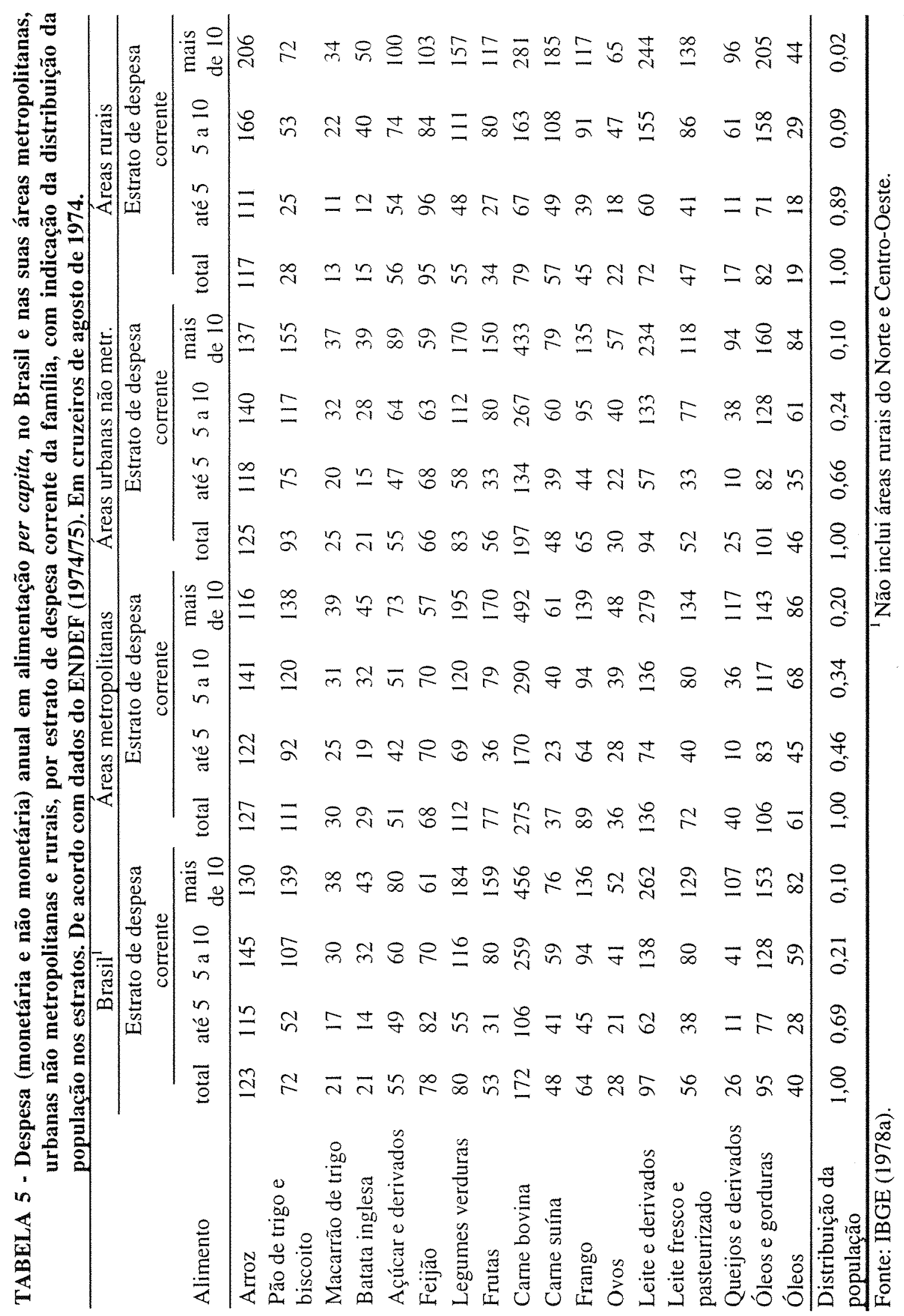


As despesas com o consumo de pão de trigo e biscoito, macarrão, legumes e verduras, carne bovina, frango são sempre maiores nas áreas urbanas do que nas rurais. Em termos de valor total, as despesas com arroz nas áreas urbanas são maiores do que nas rurais. Mas, nos estratos de dispêndio superiores a 5 salários mínimos as despesas com arroz são maiores nas áreas rurais. O mesmo comportamento é observado com a batata inglesa, ovos e óleos e gorduras.

Nas áreas rurais as despesas com feijão, carne suína, açúcares e derivados são maiores do que nas áreas urbanas, seja em termos de valor total ou na divisão por estratos. Nos três estratos de despesas correntes os gastos com leite fresco (não pasteurizado) e pasteurizado nas áreas rurais são maiores do que nas áreas urbanas. Porém, em termos de valor total essas despesas são maiores nas áreas urbanas. Isso ocorre porque nas áreas urbanas o número de pessoas nos estratos de dispêndio superiores é maior do que nas áreas rurais.

Esses resultados mostram que, ao mudarem para as áreas metropolitanas, os migrantes do meio rural tenderão a consumir maiores quantidades pão de trigo e biscoito, macarrão, legumes e verduras, carne bovina, frango etc., e diminuirão o consumo de feijão, carne suína, açúcares e derivados. Em termos de valor agregado isso fará com que o consumo médio per capita dos primeiros aumente, enquanto o consumo destes últimos se reduz. Essas mudanças ocorrerão ao longo dos anos após a migração, pois as mudanças de hábitos se processam lentamente.

A Tabela 6 mostra a evolução da urbanização da população brasileira desde 1940 até 1991 . Em 1940 pouco mais de 30\% da população residia nas zonas urbanas do país. Durante os 40 anos seguintes esse quadro se inverteu. Em 1980, pouco mais de $30 \%$ da população residia nas zonas rurais. Em 1991, menos de 1/4 da população vivia nas zonas rurais.

Como pode-se perceber, a urbanização da população foi bastante intensa nos últimas décadas e a dieta do brasileiro, certamente, foi afetada por esse processo. 
Tabela 6 - Grau de urbanização da população residente no Brasil, 1940-1991.

\begin{tabular}{lccc}
\hline Data de referência & População (1.000) & Urbana (\%) & Rural (\%) \\
\hline $1-9-1940$ & 41.236 & 31,2 & 68,8 \\
$1-7-1950$ & 51.944 & 36,2 & 63,8 \\
$1-9-1960$ & 70.070 & 44,7 & 55,3 \\
$1-9-1970$ & 93.139 & 55,9 & 44,1 \\
$1-9-1980$ & 119.003 & 67,6 & 32,4 \\
$1-9-1991$ & 146.825 & 75,6 & 24,4 \\
\hline
\end{tabular}

Fonte: ANUÁRIO ESTATÍSTICO DO BRASIL (1997), p.2-14.

\subsection{A importância da renda.}

Ernest Engel, estatístico alemão do século XIX, foi o primeiro a realizar trabalho empírico estabelecendo uma relação entre o consumo de alimentos e a renda (Miller, 1981). A Lei de Engel afirma que à medida que a renda dos indivíduos cresce, a porcentagem gasta em alimentação decresce (Ackley, 1969). No Brasil, a participação das despesas com alimentação em relação ao total das despesas das familias é substancialmente maior nas classes de mais baixa rendimentos do que nas classes de rendimentos maiores.

Para medir o efeito das variações na renda sobre o consumo de alimentos é necessário saber como o consumo de alimentos tem se comportado perante as variações ocorridas na renda dos brasileiros. Por meio dos valores médios anuais do Produto Interno Bruto (PIB) per capita pode-se saber como a renda dos brasileiros tem se comportado, porém, as informações a respeito do consumo de alimentos são menos freqüentes e estão disponiveis apenas por meio de pesquisas como o ENDEF e a POF. A Figura 1 apresenta a evolução do PIB nos anos de 1970 a 1990.

Na década de 70 , o PIB per capita cresceu a uma taxa de $6,05 \%$ ao ano, totalizando $84,8 \%$. Na década de 80 o PIB per capita diminui drasticamente sua taxa de crescimento. De 1980 até 1983 decresce 11,8\%. No ano de 1987 atinge o maior valor do período, 90,4\% maior do que em 1970, mas torna a cair entre 1987 e 1990. 
Entre 1974 e 1988, intervalo correspondente aos anos nos quais as pesquisas ÉNDEF e POF foram realizadas, houve um aumento de $32,3 \%$ no valor do PIB per capita.

Outro fator importante a se considerar quando se pretende determinar o efeito da renda sobre o consumo de alimentos é como está distribuída a renda entre a população. Entre 1970 e 1990 a renda per capita no Brasil aumentou substancialmente (ver Figura 1), mas o grau de desigualdade da distribuição da renda se manteve elevado durante todo o período. Os dados da PNAD de 1996 mostram que, no Brasil, a parcela que contém $70 \%$ da população de dez anos ou mais de idade, em ordem crescente de rendimentos, fica com apenas $25,7 \%$ do total de rendimentos mensais do pais, enquanto os $30 \%$ restantes ficam com a maior parte dos rendimentos, $74,3 \%$.

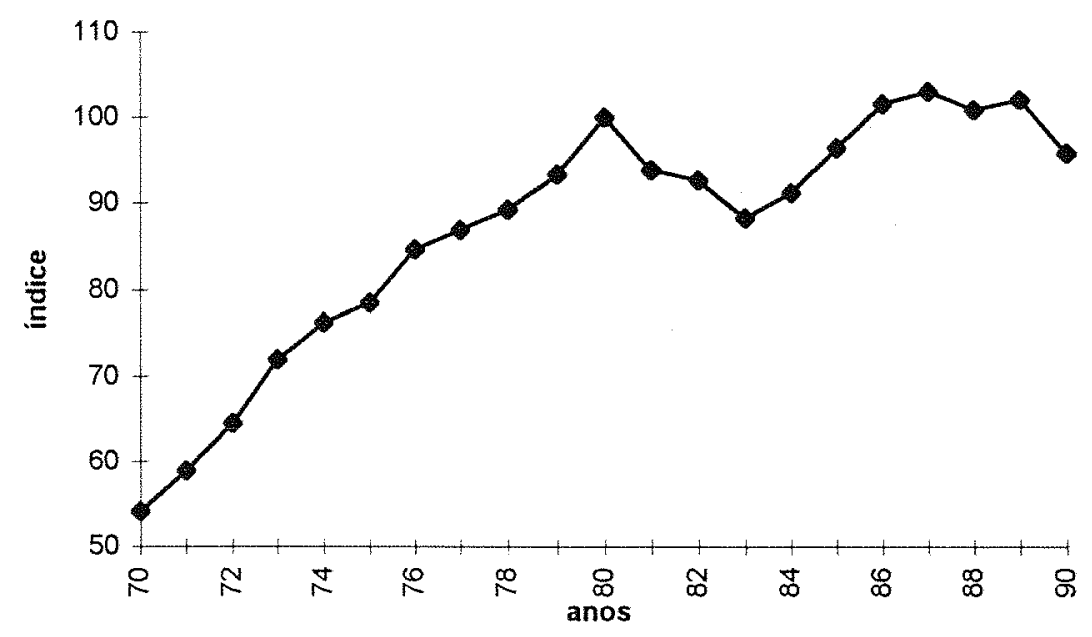

Figura 1 - Índice do PIB per capita no Brasil, 1970/90.

Fonte: IBGE (1990) e Conjuntura Econômica (1998)

\subsection{Considerações finais}

A partir das informações apresentadas neste Capítulo surgem novos questionamentos sobre o consumo de alimentos: Em termos quantitativos, como variou o consumo desses alimentos? Qual a importância dos preços dos alimentos nessas variações? Que tipo de influência as variações na renda exercem sobre o consumo de alimentos? Qual a importância da urbanização e de outras questões demográficas como o 
crescimento populacional, a diversidade da origem étnica, a idade da população, a composição das famílias etc., nas mudanças de hábitos? De que forma o estilo de vida moderno e o marketing influenciam esse consumo? Como as preocupações com a saúde e com a qualidade dos alimentos afetam o padrão alimentar? etc.

Como se pode notar, são muitos os fatores que influenciam a formação do padrão alimentar dos indivíduos. Porém, como se torna excessivamente complexa a mensuração da ação de cada um desses fatores para um grupo abrangente de alimentos, este estudo se preocupará, principalmente, com os três primeiros questionamentos apresentados no parágrafo anterior, com especial atenção para os efeitos da renda no consumo de alimentos. 


\section{OBJETIVOS}

O objetivo deste trabalho é estudar as variações no consumo de alimentos do brasileiro ocorridas entre 1974/75 e 1987/88, com base nos dados do ENDEF (IBGE, 1978a) e na POF - 87/88 (IBGE, 1991, n.1), quantificando os efeitos associados às alterações ocorridas nos preços dos produtos, na renda e nos hábitos alimentares dos dos consumidores.

Os ítens da cesta de alimentos que serão objeto desse estudo são os seguintes: arroz, feijão, carne suína, carne bovina, frango, leite, batata inglesa e ovos. Outros produtos (legumes e verduras, frutas, leite e seus derivados, açúcares e derivados, óleos e gorduras) serão estudados de forma agregada, bem como os gastos com alimentação fora do domicílio.

No desenrolar desse estudo serão obtidos:

- os coeficientes das elasticidade-renda do dispêndio com os produtos listados acima, a partir dos dados presentes na POF.

- a evolução dos preços reais. 


\section{REVISÃO DE LITERATURA}

A revisão de literatura apresentada a seguir está subdividida em três itens. No primeiro deles (4.1) serão apresentados os trabalhos que têm como enfoque principal o efeito da renda sobre o consumo de alimentos. No segundo item (4.2) serão apresentados trabalhos que tratam dos preços dos alimentos e seus efeitos sobre o consumo. O terceiro item (4.3) reunirá os trabalhos que abordam o consumo de alimentos de forma genérica e aqueles cujo enfoque está centrado nas mudanças dos hábitos.

\subsection{Renda}

Perez (1973), utilizando dados de corte transversal no tempo provenientes de amostra obtida durante o mês de julho de 1971 no município de Piracicaba-SP, estimou alguns coeficientes de elasticidade, inclusive a elasticidade-renda do consumo de alimentos, por meio de quatro métodos diferentes. A Tabela 7 mostra os coeficientes de elasticidade-renda do dispêndio calculados através do ajustamento de poligonal, por grupos de alimentos. Observa-se, em geral, que a elasticidade-renda diminui quando se passa para estratos de renda mais elevada.

Cinco dos dezesseis itens listados apresentaram diferenças significativas em dois dos três estratos considerados, a um nível de significância de 5\%. Para alguns ítens, como farinha, legumes, frango e leite, apesar de o teste $t$ não apresentar valores significativos, a elasticidade decrescente é um resultado importante. O mesmo ocorreu para os coeficientes calculados para o dispêndio total.

Para Perez (1973), a elasticidade crescente encontrada para o item peixe devese mais a fatores como educação e costume do que à renda. 
Tabela 7 - Coeficientes de elasticidade-renda do dispêndio, por grupos de alimentos calculados através do ajuste de poligonal log-log. Piracicaba, 1971.

\begin{tabular}{|c|c|c|c|c|c|}
\hline \multirow[b]{2}{*}{$\begin{array}{l}\text { Grupos de } \\
\text { alimentos }\end{array}$} & \multicolumn{3}{|c|}{ Coeficiente de elasticidade-renda } & \multirow[b]{2}{*}{$R^{2}$} & \multirow[b]{2}{*}{ teste $F$} \\
\hline & até $\mathrm{Cr} \$ 100,00$ & $\begin{array}{c}\text { mais de } \operatorname{Cr} \$ 100,00 \text { a } \\
\operatorname{Cr} \$ 250,00\end{array}$ & $\begin{array}{l}\text { mais de } \\
\operatorname{Cr} \$ 250,00\end{array}$ & & \\
\hline Leite e derivados & $1,62^{* *}$ & 1,09 & 0,33 & 0,21 & $21,9^{* *}$ \\
\hline Óleo & $1,03^{* *}$ & $0,09^{* *}$ & $-0,04$ & 0,16 & $16,2^{* *}$ \\
\hline Ovos & 0,88 & 1,71 & 0,13 & 0,11 & $10,8^{* *}$ \\
\hline Cereais & 0,45 & $-0,32$ & $-0,03$ & 0,02 & 1,7 \\
\hline Farinhas & 0,59 & 0,29 & 0,13 & 0,04 & $3,9^{* *}$ \\
\hline Tubérculos & $0,72^{* *}$ & 0,39 & 0,06 & 0,18 & $18,4^{* *}$ \\
\hline Massa e sopas & $1,25^{* *}$ & $0,27^{*}$ & 0,07 & 0,16 & $16,0^{* *}$ \\
\hline Verduras & 1,32 & 1,04 & 1,40 & 0,09 & $7,9^{* *}$ \\
\hline Açúcar & $0,93^{* *}$ & $0,11^{* *}$ & 0,28 & 0,16 & $16,2^{* *}$ \\
\hline Frutas & $2,57^{* *}$ & $-0,05^{* *}$ & 0,69 & 0,11 & $10,5^{* *}$ \\
\hline Legumes & $1,46^{* *}$ & 0,85 & 0,33 & 0,21 & $22,8^{* *}$ \\
\hline Carne de vaca & $1,66^{* *}$ & $0,47^{* *}$ & 0,72 & 0,19 & $20,0^{* *}$ \\
\hline Carne de porco & 1,52 & 1,51 & 1,43 & 0,09 & $8,6^{* *}$ \\
\hline Frango & $3,36^{* *}$ & 1,96 & 0,41 & 0,21 & $21,7^{* *}$ \\
\hline Peixe & $-0,23$ & 0,80 & 1,79 & 0,06 & $5,0^{* *}$ \\
\hline Dispêndio total & $0,69^{* *}$ & 0,46 & 0,37 & 0,53 & $94,2^{* *}$ \\
\hline
\end{tabular}

Fonte: Perez (1973).

* Significativo ao nível de $5 \%$.

** Significativo ao nível de $1 \%$.

Obs.: Na primeira coluna, o teste $t$ refere-se à hipótese de que o coeficiente é igual a zero e na segunda e terceira colunas, o teste $t$ refere-se à hipótese da diferença dessa elasticidade em relação à do estrato anterior ser igual a zero.

Rezende (1974), buscando formular um modelo que explique o comportamento do consumo de alimentos na cidade de Juiz de Fora - MG, utilizou uma amostra contendo 907 famílias, estratificada em diversas classes de renda, e estimou as funções de consumo dos principais produtos agrícolas bem como suas elasticidades. Ele 
utilizou essas elasticidades e hipóteses sobre o crescimento da população e da renda para estimar o crescimento do consumo dos produtos agrícolas e as alterações nos preços decorrentes das variações nas quantidades oferecidas.

Foram utilizadas cinco equações diferentes para ajustar as funções de consumo, sendo que os critérios de escolha para sua utilização foram: nível de significância para o teste $F$, maior coeficiente de determinação, nivel de significância para os testes $t$ e sinal correto dos coeficientes.

Com relação à estrutura alimentar o autor concluiu que "...à medida que a renda per capita se eleva, diversifica-se mais o consumo, diminuindo a importância do grupo de amiláceos e aumentando o consumo de carne, ovos, laticínios, verduras e frutas". Constatou que há desigualdade na distribuição da renda, pois $80 \%$ das pessoas detém apenas $41,5 \%$ da renda enquanto os $2 \%$ mais ricos ficam com cerca de $20 \%$ do total. Os coeficientes de elasticidade-renda da demanda mostraram-se coerentes com a teoria econômica, sendo mais elevados para as classes de renda mais baixa e decrescendo à medida que esta aumenta.

Furtuoso (1981) utilizou os dados do Estudo Nacional da Despesa Familiar (ENDEF) para analisar o efeito da redistribuição da renda disponível sobre a demanda de alimentos no estado de São Paulo.

O primeiro passo foi calcular as elasticidades-renda da demanda de alimentos, utilizando função log-inversa e também ajustando uma poligonal log-log para os dados agrupados em três estratos de renda e para quatro tipos de localização geográfica: estado de São Paulo, área metropolitana, área urbana não metropolitana e área rural. A Tabela 8 apresenta os coeficientes de elasticidade-renda calculados para o estado de São Paulo através do ajuste de poligonal $\log -\log$

Os valores dos coeficientes de elasticidade obtidos pelos dois modelos foram relativamente próximos, mas como o ajustamento da função log-inversa pressupõe que a elasticidade varie inversamente com a renda, nos estratos de renda mais alta as 
estimativas obtidas através do ajustamento da poligonal apresentaram valores mais elevados.

Tabela 8 - Coeficientes de elasticidade-renda do dispêndio por grupos de alimentos, nos estratos considerados, para o estado de São Paulo, calculados através do ajustamento de poligonal log-log a partir dos dados do ENDEF (1974/75).

\begin{tabular}{|c|c|c|c|c|c|}
\hline \multirow[b]{2}{*}{ Grupos de alimentos } & \multicolumn{3}{|c|}{ Coeficientes de elasticidades } & \multirow[b]{2}{*}{$R^{2}$} & \multirow[b]{2}{*}{ teste $F$} \\
\hline & $1^{\circ}$ estrato & $2^{\circ}$ estrato & $3^{-0}$ estrato & & \\
\hline Despesas correntes & 0,96 & 0,83 & $0,69^{*}$ & $1,000^{1}$ & $3.517,07^{* *}$ \\
\hline Despesas de consumo & 0,93 & 0,80 & $0,65^{*}$ & $1,000^{l}$ & $3.502,41^{* *}$ \\
\hline Alimentação & 0,73 & $0,33^{* *}$ & 0,24 & 0,997 & $537,67^{* *}$ \\
\hline Cereais e derivados & 0,59 & $-0,16^{* *}$ & 0,01 & 0,977 & $72,36^{* *}$ \\
\hline Tubérculos, raízes e similares & 0,53 & 0,23 & 0,13 & 0,982 & $91,05^{* *}$ \\
\hline Açúcares e derivados & 0,43 & $0,06^{*}$ & 0,18 & 0,968 & $49,90^{* *}$ \\
\hline Leguminosas e oleaginosas & 0,32 & $-0,31^{*}$ & $-0,03$ & 0,817 & $7,43^{*}$ \\
\hline Legumes e verduras & 0,76 & $0,46^{*}$ & 0,25 & 0,996 & $458,36^{* *}$ \\
\hline Frutas & 1,47 & $0,74^{* *}$ & 0,45 & 0,997 & $545,20^{*}$ \\
\hline Carnes e pescados & 1,13 & $0,42^{* *}$ & 0,20 & 0,997 & $502,96^{* *}$ \\
\hline Ovos, leite e queijos & 0,97 & $0,42^{*}$ & 0,33 & 0,994 & $269,79^{* *}$ \\
\hline Óleo e gorduras & 0,50 & $-0,04^{* *}$ & 0,04 & 0,973 & $59,89^{* *}$ \\
\hline Alimentação fora do domicilio & 0,89 & $1,15^{* *}$ & $0,51^{* *}$ & $1,000^{1}$ & $16.581,97^{* *}$ \\
\hline
\end{tabular}

Fonte: Furtuoso (1981).

* Indica que a variação do valor de elasticidade em relação ao estrato anterior é estatisticamente significativa ao nivel de $5 \%$.

** Idem ao nivel de $1 \%$.

' Por aproximação, isto é, $R^{2}>0,9995$.

O passo seguinte consistiu em projetar a demanda de alimentos considerando várias alternativas de redistribuição de renda.

Os resultados obtidos mostraram que no estrato superior a cesta de alimentos é mais diversificada, com maior participação de alimentos mais ricos nutricionalmente. Os grupos das frutas, carnes e pescados, ovos, leite e queijos, apresentaram elasticidades 
maiores que 1 no primeiro estrato de renda nos dois modelos utilizados, tanto para as áreas urbanas como para a rural. Ainda no menor estrato de renda, onde os alimentos calóricos têm destaque na estrutura do consumo, pôde-se constatar que, após a redistribuição simulada da renda esta situação se reverte, aumentando acentuadamente a participação dos alimentos com maior valor protéico e nutricional. Esses resultados mostram como a renda e a sua distribuição são fatores condicionantes do consumo.

Melo (1988), utilizando uma função semi-log, estimou as elasticidades-renda do dispêndio para diversos alimentos consumidos no país como um todo, com base nas informações do ENDEF, conforme apresentado na Tabela 9.

TABELA 9 - Elasticidade-renda do dispêndio de produtos alimentares, valores médios do Brasil e inferior/superior nas classes de renda (despesa). Dados básicos do ENDEF (1974/75).

\begin{tabular}{|c|c|c|c|c|}
\hline \multirow{2}{*}{$\begin{array}{l}\text { Produtos } \\
\text { Alimentação }\end{array}$} & \multirow{2}{*}{$\frac{\text { Valor médio }}{0,69}$} & \multicolumn{3}{|c|}{ Intervalo } \\
\hline & & 0,22 & - & 1,64 \\
\hline Frutas & 1,28 & 0,24 & - & 4,77 \\
\hline Leite e derivados & 1,10 & 0,25 & - & 5,28 \\
\hline Carne bovina & 0,99 & 0,25 & - & 3,84 \\
\hline Legumes e verduras & 0,81 & 0,24 & - & 3,32 \\
\hline Carne de frango & 0,72 & 0,24 & - & 3,40 \\
\hline Batata & 0,69 & 0,25 & - & 5,70 \\
\hline Ovos & 0,51 & 0,23 & - & 1,81 \\
\hline Carne suína & 0,29 & 0,17 & - & 0,50 \\
\hline Açúcar e derivados & 0,29 & 0,16 & - & 0,44 \\
\hline Arroz & 0 & 1 & - & 1 \\
\hline Óleos e gorduras & 0 & I & - & I \\
\hline Feijão & $-0,10$ & $-0,09$ & - & $-0,13$ \\
\hline Mandioca e derivados & $-0,36$ & $-0,20$ & - & $-0,90$ \\
\hline
\end{tabular}

Fonte: Melo (1988).

Obs: os coeficientes apresentados são significativamente diferentes de zero ao nível de $5 \%$. 
Comentando os resultados encontrados na Tabela 9, o autor afirma que o padrão de consumo alimentar deve se alterar com o desenvolvimento econômico, diminuindo a participação dos produtos básicos como o feijão, arroz e mandioca, que apresentam coeficientes com valores médios negativos ou nulos, e aumentando a participação de carnes, leite, legumes e verduras, frutas e ovos, que apresentam coeficientes positivos e maiores do que 0,5 .

Utilizando uma abordagem que considera as inter-relações de todos os bens e serviços, fundamentada na separabilidade homogênea da função utilidade, Bacchi (1989) obteve as elasticidades da demanda de carne bovina no mercado brasileiro para o período 1957-87, apresentados na Tabela 10. A função demanda foi ajustada pelo método de mínimos quadrados.

Tabela 10 - Elasticidades de demanda de carne bovina calculadas nas médias amostrais para curto e longo prazos.

\begin{tabular}{|c|c|c|}
\hline Elasticidades & Curto prazo & Longo prazo \\
\hline Preço/direta ${ }^{*}$ & $-0,48$ & $-1,09$ \\
\hline Cruzada com preço de frango ${ }^{* *}$ & 0,10 & 0,22 \\
\hline Cruzada com preço de suino ${ }^{*}$ & 0,33 & 0,73 \\
\hline Renda & 0,30 & 0,67 \\
\hline
\end{tabular}

Fonte: Bacchi (1989).

* Esses valores tendem a alterar-se ao longo da curva de demanda sendo que para preços maiores e quantidades menores as elasticidades aumentam e vice-versa.

** Valores considerados de baixa precisão devido a não significância do coeficiente estimado.

Com base nos valores das elasticidades de curto prazo a autora conclui que "...variações na renda dos consumidores têm baixa influência no consumo de carne bovina". No entanto, os valores de elasticidade-renda do dispêndio com carne bovina apresentadas nos outros trabalhos mencionados neste capitulo não mostraram essa tendência, observando-se que para os estratos de renda mais baixa foram obtidos valores maiores do que 1 
Outro resultado importante obtido por Bacchi (1989) foi que a elasticidade cruzada da demanda de carne bovina em relação ao preço da suina indicou baixo grau de substitutibilidade entre esses dois produtos.

Hoffmann (1995b) analisou o consumo de feijão no Brasil ao longo das décadas de 70 e 80 , constatou que houve uma diminuição em seu consumo de $12 \%$ a $15 \%$. Parte dessa variação pôde ser explicada pelo processo de urbanização, uma vez que o consumo de feijão dos indivíduos residentes nas áreas urbanas equivale a $70 \%$ do consumo médio de feijão dos residentes nas zonas rurais. E, de 1970 a 1991, o grau de urbanização da população brasileira passou de $55,9 \%$ para $75,5 \%$ o que, por si só, explica um decréscimo de $7 \%$ no consumo médio de feijão.

Para poder determinar se um aumento da renda dos brasileiros também teria tido alguma influência nessa diminuição do consumo de feijão, o autor estimou os coeficientes da elasticidade-renda do consumo de feijão (Tabela 11) para dez áreas urbanas do Brasil, utilizando os dados da POF de 1987/88

$\mathrm{Na} \mathrm{POF}$, as familias são agrupadas em dez classes de renda, de acordo com o seu recebimento mensal. Os nove primeiros intervalos são fechados à direita e seus limites superiores são $2,3,5,6,8,10,15,20$, e 30 pisos salariais. A décima classe inclui as familias com recebimento mensal superior a 30 pisos salariais. Os valores monetários são expressos em cruzados de outubro de 1987, quando o piso salarial era de CR $\$ 2.640,00$. O esquema de agrupamento dessas dez classes de renda em três grandes estratos teve como critério a minimização da soma dos quadrados residual da poligonal ajustada.

No primeiro estrato a elasticidade-renda do consumo de feijão é sempre positiva e no estrato mais rico a elasticidade é sempre negativa. $\mathrm{O}$ valor da elasticidaderenda média geral (ponderada) da despesa com feijão nas dez áreas urbanas é $-0,060$. Este valor explica somente pequena parte da diminuição ocorrida no consumo de feijão, pois para um aumento de $10 \%$ na renda per capita haveria uma redução de apenas $0,6 \%$ da despesa per capita com feijão dos residentes nessas metrópoles. 
Tabela 11 - Elasticidade-renda da despesa per capita com feijão em 10 áreas urbanas do Brasil, obtida com o ajustamento de uma poligonal log-log, de acordo com dados da POF.

\begin{tabular}{lccccccc}
\hline \multirow{2}{*}{ Área urbana } & $\begin{array}{c}\text { Esquema de } \\
\text { agrupamento }\end{array}$ & $R^{2}$ & \multicolumn{3}{c}{ Elasticidade no estrato } & $\begin{array}{c}\text { Elasticidade } \\
\text { média }\end{array}$ & $\begin{array}{c}\text { Teste } \\
t\end{array}$ \\
\cline { 5 - 8 } Belém & $5-4-1$ & 0,57 & 0,145 & $-0,062$ & $-0,410$ & 0,028 & 0,45 \\
Fortaleza & $2-4-4$ & 0,89 & 0,213 & $-0,115$ & $-0,255$ & $-0,059$ & $-2,14$ \\
Recife & $1-6-3$ & 0,19 & 0,315 & 0,000 & $-0,002$ & 0,037 & 0,91 \\
Salvador & $4-1-5$ & 0,66 & 0,131 & $-0,186$ & $-0,194$ & $-0,041$ & $-0,94$ \\
B. Horizonte & $1-4-5$ & 0,28 & 0,016 & 0,002 & $-0,100$ & $-0,044$ & $-1,06$ \\
R. Janeiro & $1-3-6$ & 0,12 & 0,554 & $-0,004$ & $-0,022$ & 0,018 & 0,24 \\
São Paulo & $1-6-3$ & 0,80 & 0,071 & $-0,092$ & $-0,174$ & $-0,112$ & $-3,78$ \\
Curitiba & $2-5-3$ & 0,87 & 0,089 & $-0,170$ & $-0,509$ & $-0,209$ & $-3,36$ \\
P. Alegre & $1-1-8$ & 0,94 & 0,814 & $-0,234$ & $-0,358$ & $-0,280$ & $-4,38$ \\
Goiânia & $2-7-1$ & 0,88 & 0,819 & $-0,072$ & $-0,318$ & 0,002 & 0,08 \\
\hline
\end{tabular}

Fonte: Hoffmann (1995b).

Finalmente, analisando a série de preços de feijão no varejo da cidade de São Paulo, no período de 1972 a 1988, o autor não encontrou qualquer tendência de crescimento do seu preço real. Pôde, então, concluir que a redução do consumo de feijão nas áreas urbanas está associado a mudanças nos hábitos alimentares.

Hoffmann \& Scampini (1996) analisaram a variação no consumo de leite no Brasil utilizando informações do ENDEF (1974/75) e da POF (1987/88). Eles constataram que, no intervalo de doze anos que separa as duas pesquisas, a participação do item leite e derivados no total das despesas com alimentação no domicílio, na região metropolitana de São Paulo, aumentou de $9,7 \%$ para $16,4 \%$.

Segundo os autores, este aumento de consumo não está relacionado com uma variação favorável nos preços no periodo analisado. Pelo contrário, a análise da série de preços reais do leite tipo $C$, no varejo da cidade de São Paulo, mostra um nível substancialmente maior em 1987/88 do que 1974/75. 
Com o intuito de checar se aumentos nos rendimentos das famílias poderiam ter redundado na elevação no consumo de leite e derivados ocorrida nesse período, os autores calcularam os valores dos coeficientes da elasticidade-renda da despesa com leite e derivados para nove regiões metropolitanas do Brasil (Tabela 12). Porém, apontam, para o fato dessas elasticidades estarem ligeiramente superestimadas, pois esses coeficientes foram obtidos analisando como a despesa com o produto varia em função da renda familiar, que apresenta correlação positiva com o tamanho médio da família.

Os autores encontraram uma taxa de crescimento da renda per capita, no Brasil, de $2 \%$ ao ano para esse periodo de treze anos. Como a elasticidade-renda do consumo de leite e derivados no pais não deve ser superior a 0,5 , concluem que o aumento da renda per capita determina um crescimento no consumo per capita que não deve ser superior a $1 \%$ ao ano.

Tabela 12 - Estimativas da elasticidade-renda da despesa com leite e derivados para 9 regiões metropolitanas do Brasil. Dados da POF para 1987/88.

\begin{tabular}{lc}
\hline Regiões Metropolitanas & Coeficientes de elasticidade \\
\hline Belém & 0,49 \\
Fortaleza & 0,52 \\
Recife & 0,56 \\
Salvador & 0,46 \\
Belo Horizonte & 0,50 \\
Rio de Janeiro & 0,48 \\
Curitiba & 0,39 \\
Porto Alegre & 0,35 \\
São Paulo & 0,36 \\
\hline
\end{tabular}

Fonte: Hoffmann e Scampini (1996).

Com base nas constatações de que o crescimento do consumo de leite não está sendo favorecido pelos preços e que esse aumento é maior do que o causado pela elevação da renda, os autores concluem que as variações ocorridas no consumo se devem, em grande parte, a mudanças nos hábitos alimentares associados ao processo de 
urbanização que "...leva as pessoas a darem preferência a alimentos que não exigem muito tempo de preparação. Note-se que o leite e seus derivados (queijos, iogurtes, etc.) podem ser consumidos sem quase nenhum trabalho de preparação no domicilio."

Vale destacar que no período de coleta dos dados da POF - $87 / 88$ vigorou o Programa Nacional do Leite para Crianças Carentes (PNLCC). Este programa foi instituído em 1985 pela Presidência da República e foi extinto em janeiro de 1990. O seu objetivo era distribuir diariamente um litro de leite para crianças com idade inferior a sete anos, pertencentes a famílias com renda de até 2 salários mínimos. Tendo inicio em 1986 com a distribuição de 144 milhões de litros de leite para 2,7 milhões de crianças. Em 1988 foram atendidas 7,6 milhões de crianças com a distribuição de 1,1 bilhões de litros de leite (Silva, 1995). Mas, como esse leite era obtido no varejo através de cupons distribuídos às famílias por organizações comunitárias, o seu consumo não foi computado nos dados da POF. Como mencionado anteriormente, a POF registra apenas o consumo de alimentos adquiridos através de despesas monetárias.

\subsection{Preços}

Relacionando questões como a distribuição da renda, os preços dos alimentos e o padrão de desenvolvimento agrícola, Silva (1993) discute as três causas distintas geralmente apontadas nos debates sobre a fome. A falta de produção agrícola é destacada como sendo a primeira delas e, segundo o autor, ocorreu com maior ênfase no período que compreendeu o Brasil Colônia até a Segunda Guerra Mundial. Indica que a insuficiència da oferta é a causa básica da fome, e que somente em meados da década de 60 , com a consolidação de um setor empresarial especializado em produzir alimentos, esse problema diminuiu de importância.

A estrutura de distribuição inadequada é a segunda causa da fome discutida por Silva. Ele atribui o encarecimento relativo dos produtos agrícolas alimentares no periodo que vai da década de 60 até o final da década de 70 à intermediação comercial 
inadequada. Como resposta a esse problema surgiram as Centrais de Abastecimento Alimentar - CEASA, os supermercados e os hipermercados.

A perda do poder aquisitivo, a última das três causas da fome, aparece com maior intensidade a partir da década de 80 . Segundo Silva, entre 1980 e 1991, o valor médio anual do salário mínimo reduziu-se à metade. Constata, no entanto, que nesse período "...os preços reais dos produtos agrícolas caíram, transferindo renda do campo para a cidade e atenuando o impacto da perda de poder aquisitivo dos salários".

Porém, não é consenso entre os pesquisadores que os preços relativos dos alimentos tenham baixado nesse periodo./Segundo Veiga (1990), os preços relativos dos alimentos subiram muito na década de 80 . Ele afirma ainda que essa tendência altista já se fez presente nas últimas três décadas e que a partir de 1983 se intensificou. Observa que as curvas dos preços dos alimentos no atacado e no varejo apresentam o mesmo comportamento das curvas de preços pagos e recebidos pelos agricultores. Com base neste fato identifica como principal fator impulsionador dos preços dos alimentos o comportamento altista dos preços dos insumos agrícolas.

Veiga (1990) comenta que suas conclusões contradizem especialistas da área, que consideram que os preços reais dos produtos agrícolas e o preço real dos insumos teriam baixado durante a década de 80 . O autor observou que essa contradição ocorre por ter sido utilizado como deflator o IGP/FGV, pois, ao compará-lo com qualquer outro deflator observa-se que ocorre um nítido descolamento desses índices a partir de 1980 . Dessa forma, qualquer preço deflacionado pelo IGP apresentará tendência de queda.

Em outro artigo, Veiga (1994) também discute a questão do encarecimento dos alimentos e do custo de vida no Brasil, incluindo, ainda, uma análise mais detalhada sobre os anos 90. Confirma que “... o índice de preços ao consumidor - IPC/FIPE registra não só uma persistente tendência altista do custo de alimentação como uma intensificação do fenômeno durante os anos 80". Reforça a explicação de que os preços agrícolas, nesse periodo, não baixaram tanto quanto se supunha, pois o deflator utilizado 
-IGP/FGV- superestima a inflação e, como consequência, subestima os preços deflacionados.

Silva (1993) não concorda que os preços dos insumos industrializados teriam crescido durante a década de 80 impulsionando a elevação dos preços dos alimentos, como afirma Veiga $(1990,1994)$. Para isso apóia-se nas pesquisas de Mello (1992), que vê melhora significativa das relações de troca da agricultura, barateando o custo dos insumos industriais.

Maluf (1992), assim como Veiga, vê uma elevação nos preços dos alimentos na década de 80. Quanto às causas desse aumento explica que "...o encarecimento relativo dos alimentos envolve um conjunto de fenômenos impossíveis de serem captados pela contraposição das tendências dos preços nas diferentes etapas do encadeamento produtivo". Encara a concentração do varejo em grandes unidades de auto-serviço controladas pelas redes de supermercados como determinante na formação e encarecimento dos preços. Ressalta que a formação dos preços dos alimentos, a partir de certo periodo, integra-se à lógica das estruturas de mercado oligopolistas comandadas pelo grande capital industrial. Cita alguns fatores que, ao seu ver, contribuíram para a elevação das despesas com alimentação: “... a quase estagnação da produção agrícola per capita de alimentos no Brasil; ... as alterações na composição da cesta básica, que passou a incorporar alimentos mais elaborados, portanto, com maior valor agregado."

Silva (1993) não concorda com Maluf quando este afirma que a incorporação de produtos industrializados com maior valor agregado tenha encarecido a cesta básica. Supõe, ainda, que possa ter havido um movimento contrário ao citado, isto é, "...um barateamento relativo da alimentação com o desenvolvimento da Agroindústria". Para exemplificar, cita o caso da substituição da banha de porco pelo óleo de soja ocorrida nas últimas décadas

Observando os efeitos do Plano Real, Junqueira (1995) notou que ao longo dos dez primeiros meses após sua implantação, houve uma expansão do consumo 
alimentar. Afirma que a queda da inflação e a estabilidade dos preços aumentaram o poder aquisitivo da população e as "... camadas de menor renda passaram não apenas a consumir mais, mas também optaram pela compra de produtos de melhor qualidade". As vendas de biscoito, chocolates, conservas, sucos, laticínios, bebidas não alcóolicas, sorvetes, pães, bolos, carnes e derivados lácteos aumentaram, enquanto as vendas de café, cereais, açúcar e sal, diminuiram

\subsection{Consumo}

Simon (1981), estudando o consumo de alimentos em Botucatu, entrevistou 261 famílias durante o mês de janeiro de 1978. As famílias foram classificadas em sete estratos de rendimento mensal per capita, a saber: até 0,5 salário mínimo; de 0,5 a 1; de 1 a 2 ; de 2 a 3 ; de 3 a 4 ; de 4 a 6 e mais de 6 salários mínimos, sendo os intervalos dos 6 primeiros estratos fechados à direita. A porcentagem do rendimento gasto em alimentação em relação ao dispêndio total foi de $59,9 \%$ para o primeiro estrato e $9,9 \%$ para o último.

A Tabela 13 mostra o dispêndio mensal per capita com os vários grupos de alimentos. Nota-se que na classe de renda mais elevada o total de despesas com alimentação é pelo menos 4 vezes maior do que o observado na primeira classe de renda.

Dentre outros resultados, esta pesquisa mostrou que há uma distribuição bastante desigual dos rendimentos, que se reflete numa diferenciação da estrutura de consumo. Os alimentos energéticos são os responsáveis pela maior parte dos gastos em alimentação dos estratos inferiores e nos estratos superiores os maiores gastos se dão com alimentos protéicos.

Oliveira \& Thébaud-Mony (1996), citando Combris (1990), afirmam que na França houve, ao longo dos anos, redução no consumo de cereais feculentos, elevação no consumo de frutas e legumes, produtos de origem animal, açúcar e gordura. Observam também aumento no consumo de alimentos industrializados. 
Tabela 13 - Dispêndio mensal per capita com os vários grupos de alimentos. Botucatu, 1978 (cruzeiros de 1978).

\begin{tabular}{|c|c|c|c|c|c|c|c|}
\hline \multirow{2}{*}{$\begin{array}{l}\text { Grupos de } \\
\text { alimentos }\end{array}$} & \multicolumn{7}{|c|}{ Estratos de rendimento mensal per capita, em salários mínimos. } \\
\hline & até 0,5 & de 0,5 a 1 & de 1 a 2 & de 2 a 3 & de 3 a 4 & de 4 a 6 & mais de 6 \\
\hline Leite e derivados & 19,5 & 33,3 & 56,4 & 91,4 & 122,2 & 96,8 & 123,7 \\
\hline Óleos e gorduras & 19,9 & 25,1 & 33,7 & 36,0 & 35,5 & 36,1 & 42,5 \\
\hline Ovos e frangos & 13,5 & 25,8 & 40,5 & 55,8 & 39,4 & 58,9 & 67,6 \\
\hline Cereais & 39,5 & 42,6 & 41,9 & 34,2 & 32,1 & 33,1 & 33,7 \\
\hline Tubérculos & 11,3 & 17,2 & 24,8 & 26,6 & 29,2 & 29,3 & 35,4 \\
\hline $\begin{array}{l}\text { Sopas, massas e } \\
\text { farinhas }\end{array}$ & 22,1 & 34,0 & 44,5 & 49,7 & 54,9 & 50,0 & 46,4 \\
\hline Frutas & 6.0 & 15,1 & 30,4 & 58,6 & 69,0 & 73,1 & 106,1 \\
\hline $\begin{array}{l}\text { Legumes e } \\
\text { verduras }\end{array}$ & 9,3 & 28,9 & 44,4 & 59,9 & 72,6 & 70,1 & 121,9 \\
\hline $\begin{array}{l}\text { Açúcares e } \\
\text { doces }\end{array}$ & 15,2 & 21,1 & 27,8 & 27,4 & 21,3 & 20,1 & 36,5 \\
\hline Carne de peixe & 3,6 & 4,8 & 8,3 & 9,5 & 17,3 & 19,6 & 18,8 \\
\hline Carne de porco & 2,8 & 10,6 & 12,7 & 18,5 & 36,3 & 47,7 & 36,5 \\
\hline Carne de vaca & 28,2 & 61,8 & 95,0 & 90,8 & 113,7 & 162,2 & 136,8 \\
\hline Outros $^{1}$ & 28,8 & 48,5 & 77,1 & 89,4 & 142,3 & 145,3 & 207,8 \\
\hline Total & 219,7 & 368,8 & 537,4 & 647,0 & 785,8 & 842,5 & $1.013,7$ \\
\hline
\end{tabular}

Fonte: Simon (1981).

'Este grupo inclui condimentos, chocolates, aperitivos e bebidas.

Tasco \& Menegário (1992) estudaram o consumo de frutas na região metropolitana de São Paulo para um período de cerca de trinta anos. Nesse período, houve um decréscimo nas despesas com laranja e banana, produtos de maior consumo pelas familias. Ao procederem a comparação entre os anos de 1974/75 e 1987/88 constataram que houve diversificação no consumo de frutas, com redução no consumo laranja e banana e aumento no consumo de mamão, manga, abacaxi e maçã. Notaram, nos dois períodos, que nas classes de despesa mais elevadas, o consumo da banana é substituído por outras frutas tropicais ou de clima temperado. 
Senauer et al. (1993) afirmam que, nos Estados Unidos, quando os indivíduos migram perdem alguns dos antigos hábitos alimentares, adquirindo outros novos, típicos da nova região. Razão pela qual, a expansão no consumo de comida Mexicana pode ser parcialmente explicada pela migração entre as regiões. Apesar de a grande mobilidade dos norte americanos ajudar a difundir as diferentes preferências em todo pais, persistem entre as regiões diferenças entre gostos alimentares e padrões de consumo.

Silva \& Fabrini Filho (1994) estudaram a dinâmica do Complexo Avícola nas décadas de 70 e 80 no Brasil. Analisando a elevação no consumo de carne de frango constataram que outros fatores, além dos preços favoráveis e do aumento do poder de compra da população, contribuíram para tal aumento. O marketing utilizado nesse período, a uniformidade do produto derivado do frango, a praticidade, o baixo nível de lipídios e o teor de ácidos graxos não saturados, a inexistência de períodos sazonais, etc., contribuíram tão decisivamente para a formação do novo hábito alimentar quanto os preços relativos. Concluem, finalmente, que a introdução desse hábito alimentar está associada à estruturação e consolidação do Complexo Avícola.

Faria (1997), estudando os hábitos de consumo de alimentos da população urbana de Viçosa - MG entre 1983/84 e 1991/92, verificou que arroz, feijão, pão, macarrão, fubá, açúcar e café são os alimentos mais consumidos. Também constatou que o consumo de carnes, leite, frutas, hortaliças, folhosas e legumes está relacionado diretamente ao poder aquisitivo das famílias. Carne bovina e de aves, frutas, legumes e alimentos industrializados em geral foram os produtos que apresentaram aumento em seu consumo. O feijão apresentou redução em seu consumo. 


\section{MATERIAL E MÉTODOS}

Este capitulo está subdividido em duas partes. A primeira parte traz informações referentes à Pesquisa de Orçamentos Familiares - 87/88, realizada pelo IBGE (1991, n.1), cujos dados serão utilizados neste trabalho. Na segunda parte será apresentada a metodologia de ajustamento de uma poligonal log-log aos dados fornecidos pela POF.

\subsection{Material}

O objetivo principal do IBGE ao desenvolver a POF foi realizar uma pesquisa abrangente para atualizar a estrutura de pesos de despesas das familias e, conseqüentemente, da cesta básica de consumo dos Índices de Preços ao consumidor. As pesquisas de campo foram desenvolvidas no período compreendido entre março de 1987 e fevereiro de 1988.

A mensuração do consumo alimentar domiciliar, dentre outras informações, se estendeu, nessa pesquisa, sobre 11 áreas urbanas do Brasil: Brasília, o município de Goiânia e as regiões metropolitanas de Belém, Fortaleza, Recife, Salvador, Belo Horizonte, Rio de Janeiro, São Paulo, Curitiba e Porto Alegre.

Foram pesquisados, na POF, 876 produtos que fazem parte do consumo alimentar domiciliar. Estão alocados, por critérios de afinidade, em grupos e subgrupos de alimentos, segundo suas características e propriedades de utilização. Seus valores são apresentados na forma de despesa média mensal familiar em cruzados. Os produtos de pouca importância no total das despesas das famílias têm seu valor apresentado em 
subgrupos e somente os produtos de grande importância no total das despesas têm seu valor apresentado de forma individual.

A POF foi realizada através de uma amostra de domicílios nas 11 áreas urbanas citadas (ver Tabela 14). "Ao longo de 12 meses foram pesquisados 13.611 domicilios... sendo que os domicilios foram rigorosamente distribuídos de forma a garantir a representatividade da amostra, com a cobertura de todas as estações do ano" (IBGE, 1991, n.2, p. 12). São Paulo apresentou a maior concentração urbana do País, com 15.692 milhares de pessoas. Rio de Janeiro também ocupa posição de destaque com 10.601 milhares de pessoas. Goiânia e Belém apresentaram a menor população em suas áreas urbanas, 947 e 1.141 milhares, respectivamente. O número total de pessoas abrangidas é de 44.776 milhares, correspondendo a 11.014 mil familias.

Tabela 14 - Número de domicilios pesquisados, estimativa da população urbana metropolitana e do número de familias abrangidas pela POF - 87/88 nas 11 áreas urbanas.

\begin{tabular}{lccc}
\hline Área urbana & $\begin{array}{c}\text { Total de domicilios } \\
\text { pesquisados }\end{array}$ & $\begin{array}{c}\text { População urbana } \\
\text { metropolitana estimada }\end{array}$ & Número de famílias \\
\hline Goiânia & 1.277 & 947.615 & 226.749 \\
Brasilia & 782 & 1.649 .897 & 378.506 \\
Porto Alegre & 1.064 & 2.735 .307 & 777.494 \\
Curitiba & 1.291 & 1.946 .863 & 487.284 \\
São Paulo & 1.464 & 15.692 .195 & 3.888 .185 \\
Rio de Janeiro & 1.310 & 10.601 .308 & 2.860 .879 \\
Belo Horizonte & 1.074 & 3.282 .337 & 732.552 \\
Salvador & 1.247 & 2.190 .296 & 455.178 \\
Recife & 1.353 & 2.610 .291 & 572.017 \\
Fortaleza & 1.726 & 1.978 .652 & 413.524 \\
Belém & 1.023 & 1.141 .481 & 221.720 \\
\hline Total & 13.611 & 44.776 .242 & 11.014 .088 \\
\hline
\end{tabular}

Fonte: IBGE (1991, n.1) 
A familia foi considerada como sendo "...a unidade constituída por um único morador ou conjunto de moradores que compartilham da mesma fonte de alimentação, isto é, que utilizam um mesmo estoque de alimentos e/ou realizam um conjunto de despesas alimentares comuns" (IBGE, 1991, n.1, p.28).

Foi considerado como recebimento "todos os rendimentos, seja do trabalho, de transferências e de aluguel, e outros recebimentos, tais como: vendas esporádicas de bens (móveis ou imóveis), empréstimos, aplicações de capital e outros referentes à lucros de negócios, restituição judicial, etc". (IBGE, 1991, n.1, p.36)

Como rendimento foi considerado "todo e qualquer tipo de ganho em dinheiro que tenha sido percebido durante o período de referência de seis meses anteriores a pesquisa no domicilio" seja como empregado, empregador ou conta-própria (IBGE, 1991, n.1, p.36). Os rendimentos brutos, provenientes de aposentadoria de previdência pública ou privada, pensão e abono de permanência em serviço, bolsa de estudo, pensão alimentícia, mesada, doação, herança etc são considerados como "transferências".

Rendimentos provenientes de aluguel incluem os bens móveis ou imóveis. $\mathrm{O}$ recebimento mensal familiar é "a soma dos recebimentos mensais dos componentes da familia, exclusive os empregados domésticos e seus parentes" (IBGE, 1991, n.1, p.39).

As familias são classificadas em dez classes de recebimento mensal, como mostra a Tabela 15. A primeira classe, até 2 pisos salariais, é a de menor rendimento e inclui a categoria "Sem recebimento". A última classe inclui as familias com recebimentos mensais acima de 30 pisos. A padronização dos valores monetários da pesquisa tem como data referencial o dia 15 de outubro de 1987. Durante este mês o piso salarial era de CZS $2.640,00$ (dois mil seiscentos e quarenta cruzados). 
Tabela 15 - Classes de recebimento mensal familiar em pisos salariais e em cruzados de outubro de 1987.

\begin{tabular}{cc}
\hline $\begin{array}{c}\text { Número de pisos salariais mensais } \\
\text { (classes de renda) }\end{array}$ & Em cruzados mensais \\
\hline até 2 & até 5.280 \\
mais de 2 a 3 & mais de 5.280 a 7.920 \\
mais de 3 a 5 & mais de 7.920 a 13.200 \\
mais de 5 a 6 & mais de 13.200 a 15.840 \\
mais de 6 a 8 & mais de 15.840 a 21.120 \\
mais de 8 a 10 & mais de 21.120 a 26.400 \\
mais de 10 a 15 & mais de 26.400 a 39.600 \\
mais de 15 a 20 & mais de 39.600 a 52.800 \\
mais de 20 a 30 & mais de 52.800 a 79.200 \\
mais de 30 & mais de 79.200 \\
\hline
\end{tabular}

Fonte: IBGE (1991, n. 1).

\subsection{O ajuste de uma poligonal log-log.}

Para o desenvolvimento deste trabalho será necessário estimar os coeficientes de elasticidade-renda da despesa com cada alimento a ser analisado. Esses coeficientes são essenciais para calcular a parcela das variações no consumo de cada alimento que são devidas às mudanças na renda dos consumidores.

Seja:

$X=$ renda mensal per capita,

$Y_{i}=$ dispêndio mensal per capita com o alimento $i$

O coeficiente de elasticidade-renda do dispêndio com o alimento $i$ é:

$$
\varepsilon=\frac{d Y_{i}}{d X} \cdot \frac{X}{Y_{i}}
$$


Hoffmann \& Furtuoso (1981) desenvolveram trabalho a partir de dados do ENDEF para o estado de São Paulo com o objetivo escolher um modelo que se mostrasse mais adequado à análise de dados de orçamentos familiares, dentre 3 modelos que são mais utilizados em trabalhos desse gênero.

Os autores consideraram $X_{i}$ como sendo a renda familiar média e $Y_{i}$ o dispêndio familiar médio com certo grupo de alimentos na $i$-ésima classe de renda. Também fizeram a pressuposição de que os erros do modelo de regressão $\left(u_{i}\right)$ são independentes e tem distribuição normal de média zero e variância inversamente proporcional ao número de familias na classe de renda (Hoffmann \& Furtuoso, 1981, p.458). Dessa forma ajustaram o modelo utilizando o método de mínimos quadrados ponderados, o número de famílias por classe de renda serviu como fator de ponderação.

O primeiro modelo apresentado por Hoffmann \& Furtuoso (1981, p.458) foi a função linear nos logaritmos:

$$
\log Y_{i}=\alpha+\beta \log X_{i}+u_{i}
$$

Segundo os autores, esta função tem como característica indesejável o fato de apresentar coeficiente de elasticidade constante para toda a amostra. Sabe-se que nas classes de baixa renda a elasticidade-renda da despesa com alimentos é maior que nas classes de alta renda, o que torna a hipótese de elasticidade constante insustentável.

A segunda função apresentada foi a log-inversa:

$$
\log Y_{i}=\alpha+\beta X_{i}^{-1}+u_{i}
$$

que tem como inconveniente o fato de pressupor que os coeficientes de elasticidade variam inversamente com a renda familiar. Os coeficientes de elasticidade-renda do estrato de maior renda mostraram-se menores do que aqueles obtidos através do ajustamento de poligonal log-log.

O terceiro modelo apresentado foi o seguinte: 


$$
\log Y_{i}=\alpha+\beta \log X_{i}+\sum_{h=1}^{2} \delta_{h} Z_{h i}\left(\log X_{i}-\log \theta_{h}\right)+u_{i}
$$

onde " $\theta_{h}$ é o limite superior do $h$-ésimo estrato e $Z_{h i}$ é uma variável binária tal que $Z_{h i}=0$ para $X_{i}<\theta_{h}$ e $Z_{h l}=1$ para $X_{i} \geq \theta_{h}$. Num sistema de eixos cartesianos ortogonais onde medimos $\log X_{i}$ no eixo das abcissas e $\log Y_{i}$ no eixo das ordenadas, esse modelo é representado por uma poligonal com um segmento em cada um dos três estratos. Assim, esse modelo pode ser denominado poligonal bilogarítmica ou log-log. É fácil ver que também se pode estabelecer um modelo desse tipo para dois ou para mais de três estratos" (Hoffmann \& Furtuoso, 1981, p.459).

A poligonal log-log mostrou-se mais flexível do que os modelos anteriores, pois pressupõe que a elasticidade-renda é constante somente dentro de cada estrato. Também permite que sejam feitas comparações estatísticas entre os coeficientes de elasticidade nos vários estratos considerados. Nos resultados obtidos por Hoffmann \& Furtuoso (1981) observam-se diminuições, estatisticamente significativas, nos coeficientes de elasticidade-renda quando se passa para estratos de renda familiar mais elevada. Foram essas constatações que fizeram com que esse modelo fosse recomendado pelos autores para estudos de orçamento familiares.

Outras pesquisas que utilizaram o método de ajustamento de uma poligonal também apresentaram resultados satisfatórios, contribuindo decisivamente para que esse modelo fosse adotado neste trabalho (Perez, 1973; Furtuoso, 1981; Hoffmann, 1983; Hoffmann, 1993 ; Hoffmann, 1995b; Hoffmann \& Scampini, 1996).

A estimativa da equação dessa poligonal é:

$$
\widehat{C}=a+b \log X+c Z_{1}\left(\log X-\log \theta_{1}\right)+d Z_{2}\left(\log X-\log \theta_{2}\right)
$$

onde

$$
X=\text { renda per capita }
$$


$C=\log Y$, onde $Y$ é o dispêndio per capita com determinado alimento

$\theta_{1}=$ limite superior do primeiro estrato

$\theta_{2}=$ limite superior do segundo estrato

$Z_{1}$ e $Z_{1}$ são variáveis binárias que assumem os valores:

$Z_{1}=0 \quad$ se $\quad X \leq \theta_{1}$

$Z_{1}=1 \quad$ se $\quad X>\theta_{1}$

$Z_{2}=0 \quad$ se $\quad X \leq \theta_{2}$

$Z_{2}=1 \quad$ se $\quad X>\theta_{2}$

Assim, a equação estimada do primeiro estrato será $\widehat{C}=a+b \log X$.

Será $\widehat{C}=a-c \log \theta_{1}+(b+c) \log X \quad$ para $\quad 0 \quad$ segundo estrato, onde $\left(a-c \log \theta_{1}\right)$ corresponde ao termo constante e $(b+c)$ corresponde ao coeficiente angular.

Obtém-se $\widehat{C}=a-c \log \theta_{1}-d \log \theta_{2}+(b+c+d) \log X$ para o terceiro estrato, onde $\left(a-c \log \theta_{1}-d \log \theta_{2}\right)$ corresponde ao termo constante e $(b+c+d)$ corresponde ao coeficiente angular.

A estimativa do coeficiente de elasticidade-renda do dispêndio com o alimento é $b$ no primeiro estrato, $b+c$ no segundo estrato e $b+c+d$ no terceiro estrato.

Será feito o teste $t$ para a hipótese de que a elasticidade-renda no primeiro estrato é igual à zero. No segundo e terceiro estratos, o teste $t$ refere-se à hipótese de que a diferença da elasticidade do estrato em relação à do estrato anterior é igual a zero. 
Durante o processo de ajustamento da poligonal aos dados de despesas com alimentação será necessário proceder ao agrupamento das classes de renda existentes em estratos. Como a poligonal a ser utilizada tem dois vértices, as dez classes de renda presentes na POF deverão ser convenientemente distribuidas em três estratos, cada um correspondendo a um dos segmentos de reta que compõe a poligonal. Assim o ajustamento das regressões é feito com base em 10 observações ou pontos. Para fins de análise estatística o resíduo ficou com 6 graus de liberdade. Vale ressaltar que o método de estimação utilizado para obter as estimativas dos parâmetros foi o de mínimos quadrados ponderados e o número de famílias por classe de renda serviu como fator de ponderação.

O critério principal para a escolha do melhor esquema de agrupamento das classes será a minimização da Soma de Quadrados Residual. Porém, serão descartados os resultados que apesar de apresentarem menor Soma de Quadrados Residual mostrem-se incoerentes. Espera-se que as elasticidades-renda das despesas com alimentos populares como, por exemplo, o arroz e o feijão, diminuam com a elevação da renda. Para produtos cujo consumo é mais expressivo entre as classes de maior renda, como as frutas e os legumes, outros padrões de comportamento serão aceitos.

O coeficiente de determinação $\left(R^{2}\right)$ e o coeficiente de variação $(C V)$ serão as medidas descritivas da qualidade do ajustamento da poligonal aos dados. O valor do $R^{2}$ pode variar entre zero e um $\left(0 \leq R^{2} \leq 1\right)$. Quanto mais próximo de um ele estiver, melhor terá sido a qualidade do ajustamento.

O coeficiente de variação $(C V)$ mede a dispersão relativa das observações e é definido pela relação entre o desvio padrão residual e o valor médio da variável dependente:

$$
C V=\frac{s}{W}
$$

onde 
$s=$ desvio padrão residual

$$
W=\frac{\sum_{i=1}^{n} \log Y_{i}}{n}
$$

Quanto menor for o valor do $C V$, melhor será a qualidade do ajustamento da poligonal aos dados. $\mathrm{O}$ valor do $C V$ é apresentado em porcentagem.

O teste $F$ da regressão é significativo ao nível de $5 \%$ quando o valor de $F$ da regressão for maior que 4,76 e é significativo ao nível de $10 \%$ quando for maior que 3,29 .

Vejamos como pode ser obtida uma elasticidade-renda média para toda a população a partir das elasticidades-renda em cada um dos três estratos. Para isso vamos admitir que a variação relativa na renda é a mesma nos três estratos:

$$
\frac{d X_{h}}{X_{h}}=\lambda \quad \text { para } h=1,2,3
$$

onde $X_{h}$ é a renda per capita no $h$-ésimo estrato. A elasticidade-renda no $h$-ésimo estrato é:

$$
\varepsilon_{h}=\frac{d \ln Y_{h}}{d \ln X_{h}}=\frac{d Y_{h}}{d X_{h}} \cdot \frac{X_{h}}{Y_{h}}=\frac{d Y_{h}}{\lambda Y_{h}}
$$

A elasticidade-renda do dispêndio para toda a população é

$$
\varepsilon=\frac{d Y}{\lambda Y}
$$

onde $Y$ é o dispêndio per capita médio. Se $n_{h}$ é o número de pessoas no $h$-ésimo estrato, temos 


$$
Y=\frac{\sum_{h=1}^{3} n_{h} Y_{h}}{\sum_{h=1}^{3} n_{h}}
$$

e

$$
d Y=\frac{1}{\sum_{h=1}^{3} n_{h}} \sum_{h=1}^{3} n_{h} d Y_{h}=\frac{\lambda}{\sum_{h=1}^{3} n_{h}} \sum_{h=1}^{3} \varepsilon_{h} n_{h} Y_{h}
$$

Substituindo (8) e (9) em (7) obtemos

$$
\varepsilon=\frac{\sum_{h=1}^{3} E_{h} n_{h} Y_{h}}{\sum_{h=1}^{3} n_{h} Y_{h}}
$$

Essa expressão mostra que a elasticidade global $(\mathcal{E})$ é uma média ponderada das elasticidades-renda em cada estrato $\left(\varepsilon_{h}\right)$, sendo fator de ponderação o dispêndio total de cada estrato $\left(n_{h} Y_{h}\right)$ ou a participação de cada estrato no dispêndio global com o alimento considerado:

$$
\frac{n_{h} Y_{h}}{\sum_{h=1}^{3} n_{h} Y_{h}}
$$




\section{RESULTADOS E DISCUSSÃO}

A apresentação dos resultados está separada em duas partes. A primeira parte, item (6.1), é subdividida em dois sub-ítens onde são descritas as variações no consumo médio anual per capita dos principais alimentos presentes na dieta do brasileiro e o comportamento das despesas médias anuais per capita com alimentação, utilizando os dados do ENDEF e da POF de 1974/75 e 1987/88.

A segunda parte, item (6.2), é composta por quatorze sub-ítens, contendo cada um, os resultados provenientes do ajustamento das poligonais log-log aos dados de despesas com alimentos fornecidos pela POF, a evolução nos preços desses alimentos de 1974 a 1988 e, finalmente, uma discussão sobre as variações observadas no seu consumo.

As tabelas que apresentam os resultados das regressões trazem as seguintes informações: esquema de agrupamento das classes, coeficiente de determinação $\left(R^{2}\right)$, coeficiente de variação $(\mathrm{CV})$, coeficientes de elasticidade-renda da despesa com o produto nos três estratos de renda, coeficiente de elasticidade-renda médio, os resultados do teste $t$ e o valor de $F$ da regressão.

Os preços dos alimentos utilizados neste trabalho dizem respeito apenas ao varejo da cidade de São Paulo (IEA, 1990), uma vez que não existem levantamentos com abrangência nacional como seria desejável neste tipo de trabalho. No entanto, considerase que estes preços refletem o comportamento dos preços no país pelas razões descritas no parágrafo seguinte.

A Tabela 14 mostra que a população da área urbana do município de São Paulo representa $35 \%$ da população total das onze áreas urbanas abrangidas pela POF, 
evidenciando a importância dos preços dos alimentos comercializados nesta área urbana sobre as demais áreas. Também há que se considerar que o sistema de transportes entre as principais áreas urbanas do país é razoavelmente eficiente, impedindo que o comportamento dos preços em uma dessas áreas urbanas seja muito diferente do comportamento nas demais áreas.

\subsection{Variações no consumo de alimentos}

\subsubsection{Variações nas quantidades físicas consumidas}

$\mathrm{Na}$ Tabela 16 são descritas as quantidades médias anuais dos principais ítens da cesta de alimentos consumidas pelos indivíduos das dez principais áreas urbanas do país em dois períodos distintos. Para o período de 1974/75, utiliza-se os dados do ENDEF, para $1987 / 88$, utiliza-se os dados da POF.

No ENDEF, as quantidades físicas do consumo alimentar são apresentadas por comensal-dia. O consumo alimentar foi determinado a partir da pesagem das refeições e considerando a presença dos indivíduos à mesa. Assim, são contabilizados no consumo final "...a presença irregular às refeições da família, a diferença de importância relativa das refeições e a diferença de ritmos alimentares entre as pessoas da mesma unidade alimentar e a diferença entre os ritmos diários da mesma pessoa..." (IBGE, 1978a, p.14). $\mathrm{Na}$ POF as quantidades fisicas do consumo alimentar são obtidas indiretamente. $\mathrm{O}$ valor da despesa alimentar é dividido pelo tamanho da família e o resultado final é deduzido a partir de um sistema de preços.

$\dot{E}$ importante ressaltar que a POF, ao contrário do ENDEF, não informa os valores das despesas não monetárias com alimentação, que "...correspondem a tudo que houver sido produzido, pescado, caçado, coletado ou recebido em bens (troca, doação, retirada do negócio e salários em bens) e que, pelo menos na última transação não tenha passado pelo mercado" (IBGE, 1978: p. 16). Para que os dados das duas pesquisas pudessem ser comparados utilizou-se, somente, os valores das quantidades físicas dos 
alimentos adquiridos a partir das despesas monetárias com alimentação, que referem-se, especificamente, aos gastos em dinheiro.

Ainda, no que diz respeito às quantidades consumidas, a comparação dos ítens do ENDEF e da POF que agregam alimentos em grupos, como açúcares e derivados, frutas, leite e derivados, só foi possivel mediante o reagrupamento dos dados pois são apresentados de formas diferentes nas duas pesquisas. Por exemplo, o item frutas do ENDEF, ao contrário da POF, exclui banana da terra e inclui suco e doce de frutas. Esse tipo de problema não foi resolvido plenamente em alguns casos, pois alimentos de menor consumo estão agregados nos ítens denominados outros, dificultando a sua identificação. E devido à agregação muito irregular não foi possível comparar os dados do grupo "legumes e verduras".

No intervalo de cerca de doze anos que separa estas duas pesquisas, constatase um aumento de $15,125 \mathrm{~kg}$ na quantidade per capita consumida desses alimentos, correspondendo a uma variação de 5,46\%. Cerca de metade dos ítens listados tiveram o seu consumo aumentado.

A maior variação percentual positiva é observada no consumo de frango, $59,76 \%$. A cebola aparece em segundo lugar com 52,82\%. Em terceiro lugar está o grupo do leite e derivados que apresentou uma elevação de $40,12 \%$ em seu consumo, sendo que o leite pasteurizado contribuiu substancialmente para esse aumento. Quando são feitas comparações entre os produtos tomando como base as variações nas suas quantidades em quilograma per capita, o grupo do leite e derivados apresenta-se como o de maior importância, com um aumento de $20,149 \mathrm{~kg}$ no seu consumo. Em segundo lugar está o item frutas com um aumento de $10,182 \mathrm{~kg}$. O frango aparece em terceiro lugar com um aumento de $5,455 \mathrm{~kg}$. 
Tabela 16 - Consumo médio anual de alimentos em 10 áreas urbanas do Brasil ${ }^{1}$. Por comensal-dia no ENDEF (1974/75) e per capita na POF (1987/88).

\begin{tabular}{|c|c|c|c|c|c|c|}
\hline \multirow[b]{2}{*}{ Alimento } & \multicolumn{2}{|c|}{ ENDEF (1974/75) } & \multicolumn{2}{|c|}{ POF $(1987 / 88)$} & \multicolumn{2}{|c|}{ Variações } \\
\hline & $\mathrm{kg}$ & $\begin{array}{l}\text { Outras } \\
\text { unidades }\end{array}$ & $\mathrm{kg}$ & $\begin{array}{l}\text { Outras } \\
\text { unidades }\end{array}$ & $\%$ & $\mathrm{~kg}$ \\
\hline Arroz & 37,122 & & 30,222 & & $-18,59$ & $-6,900$ \\
\hline Feijão & $-17,643$ & & $\ldots 11,973$ & & $-32,14$ & $-5,670$ \\
\hline Óleos e gorduras & 11,697 & & 11,827 & & 1,11 & 0,130 \\
\hline - Óleo de soja & 5,881 & $6,379 \ell$ & 8,079 & $8,762 \ell$ & 37,36 & 2,197 \\
\hline Carne suína & 2,466 & & 2,532 & & 2,68 & 0,066 \\
\hline Carne bovina & 18,396 & & 18,325 & & $-0,38$ & $-0,071$ \\
\hline Frango & 9,129 & & 14,584 & & 59,76 & 5,455 \\
\hline Frutas & 37,934 & . & 48,116 & & 26,84 & 10,182 \\
\hline - Banana & 8,160 & $6,664 \mathrm{dz}$ & 10,746 & $7,783 \mathrm{dz}$ & 17,32 & 1,586 \\
\hline - Laranja & 17,553 & $9,298 \mathrm{dz}$ & 17,335 & $9,174 \mathrm{dz}$ & $-1,24$ & $-0,218$ \\
\hline \multicolumn{7}{|l|}{ Legumes e verduras } \\
\hline - Tomate & 7,936 & & 6,279 & & $-20,88$ & $-1,657$ \\
\hline - Cebola & 4,269 & & 6,524 & & 52,82 & 2,255 \\
\hline - Alface & 1,671 & 7,793 pés & 1,246 & 5,855 pés & $-25,42$ & $-0,425$ \\
\hline - Total & 13,876 & & 14,049 & & 1,25 & 0,173 \\
\hline Batata inglesa & 15,172 & & 13,114 & & $-13,56$ & $-2,058$ \\
\hline Leite e derivados & 50,218 & & 70,367 & & 40,12 & 20,149 \\
\hline - Leite fresco & 1,755 & $1,701 \ell$ & 1,621 & $1,570 \ell$ & $-7,66$ & $-0,135$ \\
\hline - Pasteurizado & 44,242 & $42,870 \ell$ & 64,265 & $62,272 \ell$ & 45,26 & 20,023 \\
\hline - Leite em pó & 1,675 & & 1,152 & & $-31,23$ & $-0,523$ \\
\hline - Queijos & 1,652 & & 2,315 & & 40,12 & 0,663 \\
\hline Ovos & 6,184 & $7,977 \mathrm{dz}$ & 7,010 & $9,023 \mathrm{dz}$ & 13,35 & 0,826 \\
\hline Açúcares e derivados & 25,602 & & 25,883 & & 1,10 & 0,281 \\
\hline - Açúcar ${ }^{2}$ & 24,537 & & 22,437 & & $-8,56$ & $-2,100$ \\
\hline Pão francês & 25,834 & & 20,083 & & $-22,26$ & $-5,751$ \\
\hline Macarrão & 5,940 & & 4,274 & & $-28,30$ & $-1,687$ \\
\hline Total & 277,234 & & 292,358 & & 5,46 & 15,125 \\
\hline
\end{tabular}


Em termos percentuais, o feijão apresenta a maior redução de consumo no período: $32,14 \%$. Observa-se, também, uma redução expressiva no consumo do macarrão e de alface, $28,30 \%$ e $25,42 \%$, respectivamente. O consumo de pão francês diminuiu $22,26 \%$. A maior redução em termos de peso per capita é observada no consumo do arroz: $6,900 \mathrm{~kg}$. Em seguida está o pão francês com $5,751 \mathrm{~kg}$, o feijão com $5,670 \mathrm{~kg}$ e a batata inglesa com $2,058 \mathrm{~kg}$. Estes resultados serão discutidos novamente nos ítens específicos de cada produto.

\subsubsection{Variações nas despesas com alimentação}

A Tabela 17 apresenta a média das despesas anuais per capita com alimentação no Brasil, em dois períodos distintos, 1974/75 e 1987/88. Foi construída a partir das informações de despesas com alimentos presentes no ENDEF e na POF.

Para deflacionar as despesas com alimentação e os preços dos produtos foram testados três índices de preços diferentes com o objetivo de detectar qual deles reflete melhor a inflação no período analisado. O teste consistiu na comparação do valor da variação percentual da despesa global fornecidos pelo ENDEF (despesa monetária global) e pela POF (desembolso global) para os anos de 1974/75 e 1987/88, respectivamente, com o valor da variação do PIB per capita no período. O índice escolhido foi aquele que forneceu um valor da variação das despesas globais mais próximo do valor da variação do PIB entre 1974 e 1988.

$\mathrm{O}$ índice que apresentou $\mathrm{o}$ melhor resultado foi obtido através do encadeamento de dois índices: Índice Geral de Preços ao Consumidor (IGPC) e Índice Nacional de Preços ao Consumidor (INPC). O primeiro deles, o IGPC, foi usado para o período de janeiro de 1974 a março de 1979, e no período restante utilizou-se o INPC. Este procedimento se justifica pelo fato de nenhum dos dois índices ter sido levantado para todo o período de análise (1974/1988) e por não existir um outro índice de preços pagos pelo consumidor com a abrangência que estes dois possuem. Utilizando-se este indice observa-se uma elevação de $38,0 \%$ nas despesas globais para o período de 
1974/75 a 1987/88, enquanto que a elevação do PIB per capita para esse período foi de $32,3 \%$.

Os outro dois indices testados foram o Índice de Preços ao Consumidor (IPCalimentos) levantado pela FIPE e o Índice Geral de Preços - Disponibilidade Interna (IGP-DI) levantado pela FGV. Ambos foram preteridos pois, com a sua utilização obtivese valores de variação da despesa global que são muito distantes da elevação de $32,3 \%$ observada no PIB per capita nesse período.

O total das despesas com os ítens listados na Tabela 17 se elevou, entre 1974/75 e 1987/88, em 9,69\%, o equivalente a Cz\$ 303,53. No entanto, quando são consideradas apenas as despesas com alimentação dentro do domicílio, observa-se uma redução de $9,60 \%$ nessas despesas, pois os gastos com a maioria dos alimentos foi reduzido

As despesas com alimentação fora do lar mais que dobraram. A sua participação no total de despesas com alimentação passou de 16,37\% em 1974/75 para $31,04 \%$ em 1987/88. Mas, quando se considera todos os alimentos consumidos pelos brasileiros, e não apenas os que estão listados na Tabela 17, observa-se que as despesas com alimentação fora do lar, que representavam 13\% do total das despesas com alimentação em 1974/75, elevaram-se para $25 \%$ em $1987 / 88$.

$\mathrm{O}$ item que apresentou maior diminuição em suas despesas foi o óleos e gorduras, 68,96\%, mas mesmo assim observa-se um aumento em seu consumo (ver Tabela 16). A diminuição nos preços do óleo de soja teve um efeito decisivo nessa redução nas despesas, como será visto posteriormente.

Outro produto que apresentou grande diminuição em suas despesas foi a cebola $(52,73 \%)$ e mesmo assim, foi um dos produtos que apresentou maior aumento no consumo físico. O arroz, o feijão e o tomate também se destacaram pela grande diminuição em suas despesas. 
Tabela 17 - Despesa média anual per capita com alimentação em 1974/75 e 1987/88 para 10 áreas urbanas do Brasil, segundo os dados do ENDEF e da POF. Valores em Cruzados deflacionados pelo encadeamento dos índices INPC e Índice Geral de Preços ao Consumidor (Cruzados de março de 1986).

\begin{tabular}{|c|c|c|c|}
\hline & $\operatorname{ENDEF}(1974 / 75)$ & POF(1987/88) & Variação \\
\hline Alimento & $\mathrm{C} z \$$ & $\mathrm{Cz} \$$ & $\%$ \\
\hline Arroz & 273,56 & 146,64 & $-46,40$ \\
\hline Feijão & 142,39 & 83,62 & $-41,27$ \\
\hline Óleos gorduras & 227,07 & 70,48 & $-68,96$ \\
\hline Carne suína & 73,18 & 45,11 & $-38,36$ \\
\hline Carne bovina & 582,61 & 471,76 & $-19,03$ \\
\hline Frango & 180,09 & 176,46 & $-2,02$ \\
\hline Frutas ${ }^{2}$ & 151,04 & 232,77 & 54,11 \\
\hline -Banana & 29,35 & 41,93 & 42,86 \\
\hline \multicolumn{4}{|l|}{ Legumes e verduras } \\
\hline -Tomate & 45,09 & 26,09 & $-42,15$ \\
\hline -Cebola & 32,59 & 15,41 & $-52,73$ \\
\hline -Alface & 14,25 & 11,84 & $-16,91$ \\
\hline -Total & 91,94 & 53,34 & $-41,98$ \\
\hline Batata inglesa & 60,75 & 35,32 & $-41,87$ \\
\hline Leite e derivados & 359,10 & 510,89 & 42,27 \\
\hline -Leite ${ }^{3}$ & 153,85 & 253,76 & 64,94 \\
\hline Ovos & 73,25 & 56,60 & $-22,73$ \\
\hline Açúcares e derivados & 107,18 & 193,46 & 80,50 \\
\hline Pão francès e biscoito & 235,25 & 246,05 & 4,59 \\
\hline Macarrão & 63,73 & 46,90 & $-26,41$ \\
\hline Alimentação fora do domicílio & 511,28 & $1.066,55$ & 108,61 \\
\hline Total & $3.132,42$ & $3.435,95$ & 9,69 \\
\hline
\end{tabular}

Fonte: IBGE (1978a); IBGE (1991, n. 1).

'No ENDEF são apresentados valores de despesas com "frango e galinha" enquanto a POF refere-se apenas a frango.

${ }^{2} \mathrm{O}$ item "frutas" do ENDEF, ao contrário da POF, não inclui os valores de despesas com banana da terra.

${ }^{3} \mathrm{O}$ ENDEF apresenta as despesas com leite pasteurizado e leite fresco agregadas. A POF inclui nesse item apenas as despesas com leite pasteurizado.

Três grupos de alimentos se destacaram pela elevação das despesas com o seu consumo: frutas, leite e derivados e açúcares e derivados. $E$, como se pode ver na Tabela 
16, todos estes grupos tiveram seu consumo físico aumentado nesse período. As despesas com alimentação fora do domicilio mais que dobraram nesse período.

Em 1974/75, a carne bovina era o produto isolado que apresentava o maior valor de dispêndio, $\mathrm{Cz} \$ 582,61$. O segundo em ordem de importância, era o grupo do leite e derivados e em seguida, o arroz. Porém, em 1987/88 as despesas com carne bovina diminuíram substancialmente e o grupo do leite e derivados se tornou o de maior dispêndio.

\subsection{Apresentação dos resultados por alimento ou grupo de alimentos}

\subsubsection{Arroz}

$\mathrm{Na}$ Tabela 18 encontram-se os resultados do ajustamento das poligonais loglog aos dados de despesa com o consumo de arroz para onze áreas urbanas do Brasil. Os dados utilizados são provenientes da POF e correspondem aos anos de 1987/88.

Nota-se que em três dessas onze áreas o teste $F$ não é significativo ao nível de 10\%: Brasilia, São Paulo e Salvador. É significativo ao nivel de 5\% em Goiânia, Curitiba, Rio de Janeiro, Belo Horizonte, Recife e Fortaleza e é significativo ao nível de $10 \%$ em Porto Alegre e Belém. Conseqüentemente, os valores do coeficiente de determinação $\left(R^{2}\right)$ são bastante elevados nessas áreas. O coeficiente de variação $(C V)$ apresenta valores baixos, sendo que somente em Brasilia encontra-se acima de $5 \%$, indicando que a relação entre a variação residual $(s)$ e o valor médio da variável dependente é pequena.

Em todas as áreas urbanas estudadas, os coeficientes de elasticidade-renda das despesas com arroz sempre diminuem quando se passa para um estrato de renda mais alta. No primeiro estrato, que é formado pelos indivíduos de mais baixa renda, os coeficientes de elasticidade são positivos, exceto em Curitiba. Observa-se, também, que na maioria dos casos, o primeiro estrato é formado apenas pela classe de renda mais baixa, mostrando a grande importância que esse produto tem para os indivíduos mais pobres. 
No segundo estrato, observa-se que somente Goiânia, Porto Alegre e Curitiba apresentam elasticidade-renda negativa; as localidades restantes apresentam elasticidades positivas. No terceiro estrato, Recife e Salvador são as únicas áreas a apresentarem elasticidades positivas.

TABELA 18 - Coeficientes de Elasticidade-renda da despesa per capita com arroz nos estratos considerados para 11 áreas urbanas do Brasil, obtidos através do ajustamento de uma poligonal log-log de acordo com dados da POF (198788).

\begin{tabular}{lccccccccc}
\hline & Esquema de & $R^{2}$ & $C V$ & \multicolumn{2}{c}{ Elasticidade do estrato } & Elasticidade & Valor \\
Area urbana & agrupamento & & $\%$ & I & II & III & média $^{1}$ & de $F$ \\
\hline Goiània & $1-3-6$ & 0,87 & 1,8 & 0,824 & $-0,053$ & $-0,189$ & $-0,091$ & $13,92^{* *}$ \\
Brasilia & $1-2-7$ & 0,18 & 5,9 & 0,505 & 0,119 & $-0,104$ & $-0,027$ & 0,44 \\
Porto Alegre & $1-7-2$ & 0,67 & 3,1 & 0,157 & $-0,043$ & $-0,377$ & $-0,084$ & $4,02^{*}$ \\
Curitiba & $3-4-3$ & 0,81 & 3,0 & $-0,066$ & $-0,204$ & $-0,257$ & $-0,177$ & $8,34^{* *}$ \\
São Paulo & $1-6-3$ & 0,32 & 3,7 & 0,260 & 0,083 & $-0,185$ & $-0,002$ & 0,96 \\
Rio de Janeiro & $2-1-7$ & 0,81 & 1,5 & $0,608^{* *}$ & 0,050 & $-0,071$ & 0,045 & $8,61^{* *}$ \\
Belo Horizonte & $1-6-3$ & 0,82 & 1,5 & $0,459^{*}$ & $0,020^{*}$ & $-0,266^{*}$ & $-0,012$ & $9,29^{* *}$ \\
Salvador & $3-3-4$ & 0,17 & 3,4 & 0,073 & 0,042 & 0,014 & 0,043 & 0,41 \\
Recife & $1-3-6$ & 0,79 & 3,3 & 0,334 & 0,162 & 0,130 & 0,162 & $7,62^{* *}$ \\
Fortaleza & $1-7-2$ & 0,96 & 1,0 & $0,485^{*}$ & $0,124^{*}$ & $-0,217^{*}$ & 0,120 & $44,67^{* *}$ \\
Belém & $6-3-1$ & 0,65 & 2,7 & 0,169 & 0,115 & $-0,089$ & 0,122 & $3,70^{*}$ \\
\hline
\end{tabular}

Fonte: Dados da IBGE $(1991, \mathrm{n} .1)$ processados pelo autor.

${ }^{1}$ A elasticidade média geral ponderada para as 11 áreas urbanas é de 0,009.

No primeiro estrato o teste $t$ refere-se à hipótese de que a elasticidade-renda é igual a zero. No segundo e terceiro estratos, o teste $t$ refere-se à hipótese de que a diferença da elasticidade do estrato em relação à do estrato anterior é igual a zero.

** Significativo ao nivel de $5 \%$.

* Significativo ao nível de $10 \%$. 
Em Belo Horizonte e Fortaleza, as variações entre os coeficientes de elasticidade dos três estratos considerados são estatisticamente significativas pelo teste $t$, a um nível de $10 \%$. Estas duas áreas urbanas, juntamente com o Rio de Janeiro apresentam coeficientes do primeiro estrato estatisticamente diferentes de zero. Nas demais áreas as variações entre os estratos não são significativas estatisticamente.

Em Recife, Fortaleza e Belém, o coeficiente de elasticidade média assume valores acima de 0,100 e em Curitiba está abaixo de -0,100. Nas localidades restantes a elasticidade média apresenta valores intermediários a estes. Ponderando seu valor para as onze áreas urbanas, obtém-se uma elasticidade média geral de 0,009. Utilizando dados fornecidos pelo ENDEF referentes a 1974/75, para o Brasil como um todo, Melo (1988) obteve o valor zero para o coeficiente médio da elasticidade-renda do dispêndio com arroz, o que é bastante coerente com o resultado obtido neste trabalho.

A Figura 2 apresenta a variação do preço médio real do arroz no varejo da cidade de São Paulo nos anos de 1974 a 1988. O ano de 1975 apresentou um crescimento de $15 \%$ em relação ao ano anterior. Nos anos seguintes, os preços médios mantiveram-se sempre abaixo do valor inicial. $\mathrm{O}$ ano de 1987 apresentou o menor valor do período, com o arroz custando em média 41\% menos do que em 1974. Em 1988 houve uma pequena elevação nos preços, mas, mesmo assim, o preço médio deste produto representou $71 \%$ do valor de 1974 . O preço médio do período no qual a pesquisa ENDEF foi realizada, agosto de 1974 a agosto de 1975, é praticamente o dobro daquele observado entre março de 1987 a fevereiro de 1988, período no qual os dados de campo da POF foram obtidos.

Essa redução observada nos preços do arroz deveria ter estimulado o seu consumo. No entanto observou-se, no periodo estudado, uma redução no consumo per capita desse produto como veremos a seguir.

De acordo com a Tabela 16, o consumo médio anual per capita de arroz no periodo que separa as pesquisas ENDEF (1974/75) e POF (1987/88), diminuiu 18,59\%, 
o equivalente a $6,900 \mathrm{~kg}$. Essa diminuição no consumo foi acompanhada por uma redução nas despesas monetárias per capita com esse produto de 46,40\% (ver Tabela 17).

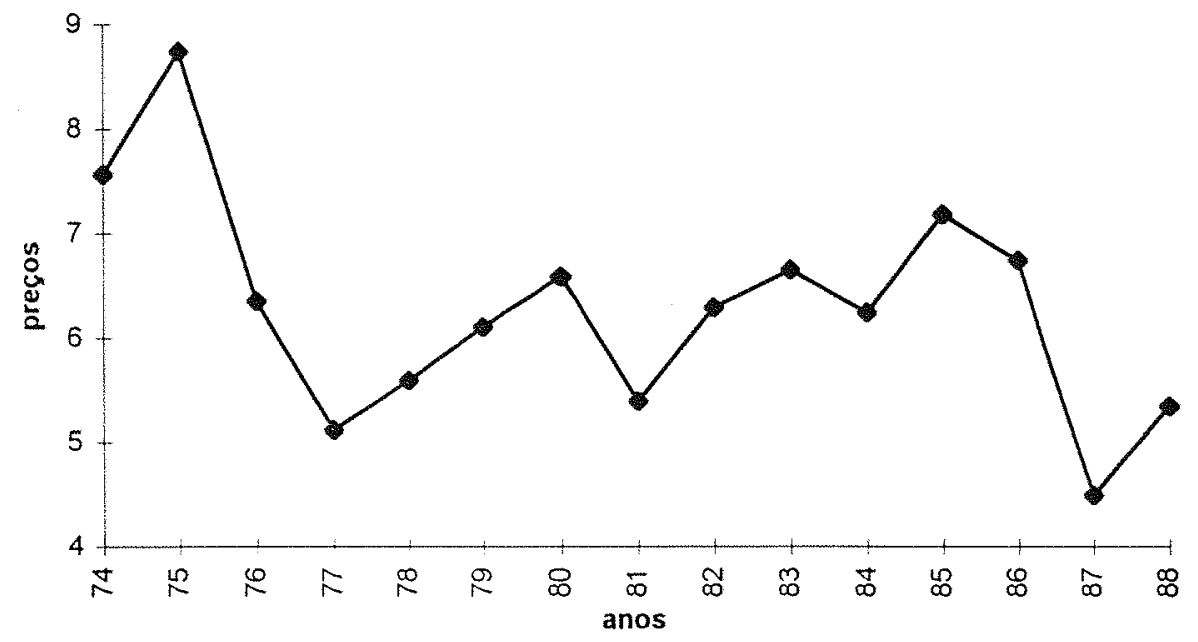

Figura 2 - Preços médios anuais do arroz (kg) no varejo da cidade de São Paulo 1974/88. Em cruzados de março de 1986.

Fonte: Dados do IEA (1990) processados peio autor.

O coeficiente de elasticidade média geral $(0,009)$ indica que o aumento de $32 \%$ observado no PIB per capita entre os anos de 1974 e 1988 seria capaz de causar uma elevação, embora pequena, nas despesas com o consumo de arroz desde que a distribuição da renda tivesse se mantido inalterada nesse período. Este resultado, assim como aquele obtido na análise dos preços, não é capaz de explicar a redução observada no consumo de arroz, razão pela qual considera-se que as mudanças nos hábitos alimentares são a causa provável da diminuição no consumo desse alimento.

$\mathrm{O}$ aumento das despesas com alimentação fora do domicílio e a maior diversificação da dieta dos brasileiros são as principais causas da redução observada no consumo de arroz. A Tabela 16 mostra que os indivíduos diversificaram suas refeições, consumindo maiores quantidades de frutas, leite pasteurizado, queijos e carne de frango. Em comparação ao arroz, estes alimentos têm a vantagem de exigirem pouco tempo de preparo para serem consumidos, além de possuírem características nutricionais superiores. 
No item seguinte, veremos que o feijão, principal acompanhante do arroz, também apresentou redução em seu consumo. Isto mostra que o hábito tradicional de consumir estes produtos nas duas refeições básicas do dia certamente vem perdendo espaço para alimentos mais ricos nutricionalmente, que exijam pouco tempo de preparo e que, ao mesmo tempo, satisfaçam o paladar.

\subsubsection{Feijão}

A Tabela 19 apresenta os resultados dos ajustamentos de poligonais log-log aos dados de despesa com feijão de dez áreas urbanas ${ }^{2}$ do Brasil fornecidos pela POF. No Rio de Janeiro, Belo Horizonte, Recife e Belém, encontram-se valores baixos no coeficiente de determinação $\left(R^{2}\right)$. Conseqüentemente, seus valores de $F$ não são significativos ao nivel de $10 \%$. O valor de $F$ de Salvador é significativo ao nível de $10 \%$ e seu coeficiente de determinação $\left(R^{2}\right)$ é 0,66 . As demais áreas urbanas apresentam valores de $F$ significativos ao nível de $5 \%$ e valores elevados nos coeficientes de determinação $\left(R^{2}\right)$.

O coeficiente de variação $(C V)$, por sua vez, exibe valores que estão abaixo ou muito próximos de $5 \%$, inclusive nas áreas urbanas onde o coeficiente de determinação $\left(R^{2}\right)$ apresenta valores bastante próximos de zero, indicando, assim, boa qualidade nos ajustamentos.

Os coeficientes de elasticidade-renda da despesa com feijão apresentam-se decrescentes entre os estratos em todas as áreas urbanas estudadas. No primeiro estrato todos os coeficientes de elasticidade-renda apresentam sinais positivos mas, de maneira semelhante ao que foi observado nos resultados do arroz (Tabela 18), esse estrato é, freqüentemente, constituído por apenas uma classe de renda. No segundo estrato somente Rio de Janeiro, Belo Horizonte e Recife apresentam sinais positivos. No terceiro estrato a elasticidade-renda é sempre negativa.

\footnotetext{
${ }^{2}$ Nenhum dos esquemas de agrupamento obtidos para a área urbana de Brasília apresentou resultados satisfatórios. Portanto não foram apresentados.
} 
TABELA 19 - Coeficientes de Elasticidade-renda da despesa per capita com feijão nos estratos considerados para 10 áreas urbanas do Brasil, obtidos através do ajustamento de uma poligonal log-log de acordo com dados da POF (198788).

\begin{tabular}{|c|c|c|c|c|c|c|c|c|}
\hline \multirow[b]{2}{*}{ Área urbana } & \multirow{2}{*}{$\begin{array}{l}\text { Esquema de } \\
\text { agrupamento }\end{array}$} & \multirow[t]{2}{*}{$R^{2}$} & \multirow{2}{*}{$\begin{array}{l}\mathrm{CV} \\
\%\end{array}$} & \multicolumn{3}{|c|}{ Elasticidade do estrato } & \multirow{2}{*}{$\begin{array}{c}\text { Elasticidade } \\
\text { média }^{1}\end{array}$} & \multirow{2}{*}{$\begin{array}{l}\text { Valor } \\
\text { de } F\end{array}$} \\
\hline & & & & I & II & III & & \\
\hline Goiânia & $1-8-1$ & 0,89 & 2,1 & $1,442^{*}$ & $-0,043^{* *}$ & $-0,374^{* *}$ & $-0,016$ & $16,38^{* *}$ \\
\hline Porto Alegre & $1-7-2$ & 0,94 & 3,1 & $0,862^{* *}$ & $-0,348^{* *}$ & $-0,376$ & $-0,282$ & $33,00^{* *}$ \\
\hline Curitiba & $3-6-1$ & 0,88 & 5,0 & 0,003 & $-0,266$ & $-0,726$ & $-0,214$ & $14,76^{* *}$ \\
\hline São Paulo & $1-6-3$ & 0,80 & 2,0 & 0,071 & $-0,092$ & $-0,174$ & $-0,112$ & $7,98^{* *}$ \\
\hline Rio de Janeiro & $2-1-7$ & 0,13 & 5,4 & 0,367 & 0,014 & $-0,028$ & 0,034 & 0,30 \\
\hline Belo Horizonte & $1-4-5$ & 0,28 & 3,3 & 0,016 & 0,002 & $-0,100$ & $-0,044$ & 0,77 \\
\hline Salvador & $4-1-5$ & 0,66 & 3,1 & 0,131 & $-0,186$ & $-0,194$ & $-0,041$ & $3,97^{*}$ \\
\hline Recife & $1-8-1$ & 0,19 & 3,4 & 0,297 & 0,009 & $-0,048$ & 0,038 & 0,48 \\
\hline Fortaleza & $1-5-4$ & 0,89 & 1,8 & 0,384 & $-0,093$ & $-0,260$ & $-0,061$ & $16,19^{* *}$ \\
\hline Belém & $4-5-1$ & 0,59 & 3,7 & 0,183 & $-0,050$ & $-0,413$ & 0,020 & 2,90 \\
\hline
\end{tabular}

Fonte: Dados da IBGE (1991, n. 1) processados pelo autor.

' A elasticidade média geral ponderada para as 10 áreas urbanas é de $-0,057$.

No primeiro estrato o teste $t$ refere-se à hipótese de que a elasticidade-renda é igual a zero. No segundo e terceiro estratos, o teste $t$ refere-se à hipótese de que a diferença da elasticidade do estrato em relação à do estrato anterior é igual a zero.

** Significativo ao nível de $5 \%$.

* Significativo ao nivel de $10 \%$.

Goiânia apresenta nos seus coeficientes de elasticidade variações estatisticamente significativas ao nível de $5 \%$ entre os três estratos. Em Porto Alegre, essas variações são significativas apenas entre o primeiro e segundo estratos, sendo que nas demais áreas as variações não são estatisticamente significativas entre os estratos. 
Porto Alegre, Curitiba e São Paulo apresentam coeficientes médios de elasticidade-renda abaixo de $-0,100$. Nas demais áreas, os coeficientes estão sempre próximos de zero, sendo positivos no Rio de Janeiro, Recife e Belém e negativos em Goiânia, Belo Horizonte, Salvador e Fortaleza. A elasticidade média geral, ponderada para as dez áreas urbanas, é -0,057. Hoffmann (1995b) obteve, a partir da mesma fonte de dados e da mesma metodologia utilizada neste trabalho, o valor $-0,060$ para o coeficiente de elasticidade média geral. Utilizando dados fornecidos pelo ENDEF referentes a 1974/75, para o Brasil como um todo, Melo (1988) obteve o valor $-0,10$ para o coeficiente médio da elasticidade-renda do dispêndio com feijão, valor coerente com o resultado obtido no presente trabalho.

Como pode ser visto na Figura 3, os preços médios do feijão apresentaram-se instáveis entre os anos de 1974 a 1988. Nota-se nos anos de 1976, 1981 e 1984 uma tendência marcante de elevação nos preços, sendo que, em relação ao valor inicial de 1974, representaram um aumento de $57 \%$, 42\% e 44\%, respectivamente. Mas pode-se observar periodos onde os preços reduziram-se consideravelmente, como em 1979 e 1982, quando os mesmos foram $17 \%$ e $32 \%$ menores do que o observado em 1974 Comparando-se os anos de 1974 e 1988, obtém-se uma redução de $11 \%$ nos preços. A redução observada entre os preços médios dos períodos específicos nos quais as pesquisas ENDEF e POF foram realizadas é um pouco menor: $10 \%$.

Essa redução no preço médio, ceteris paribus, deveria causar um aumento no consumo.

A Tabela 16 mostra que no período de cerca de 12 anos que separa as duas pesquisas (ENDEF e POF), o feijão apresenta um decréscimo em seu consumo de $32,14 \%$ ou $5,670 \mathrm{~kg}$. Essa variação corresponde, em termos monetários, a uma redução de $41,27 \%$ nas despesas com o produto (ver Tabela 17 ).

O coeficiente de elasticidade média geral calculado para esse produto, $-0,057$, explica apenas uma pequena parte dessa redução no seu consumo pois, considerando-se 
que nesse período, a distribuição da renda manteve-se inalterada e que o aumento no PIB per capita foi de $32 \%$, obtém-se uma redução de apenas $1,8 \%$ nas despesas com feijão dos indivíduos residentes nas principais áreas urbanas do Brasil.

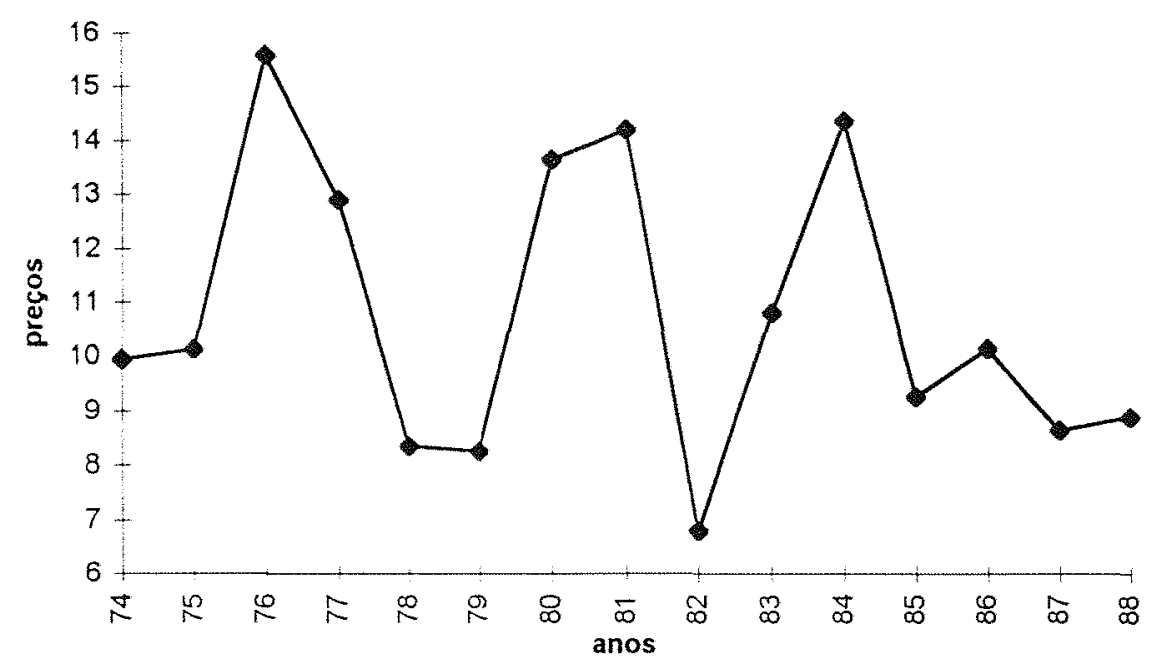

Figura 3 - Preços médios anuais do feijão (kg) no varejo da cidade de São Paulo 1974/88. Em cruzados de março de 1986.

Fonte: Dados do IEA (1990) processados pelo autor.

Como a redução no consumo de feijão não foi causada pelos preços e como a elevação da renda per capita explica apenas uma pequena parcela dessa variação, deduzse que ocorreu mudança de hábito alimentar associada com certas características desse produto. Hoffmann (1995b) associa a redução do consumo de feijão ao processo de urbanização da população que vem ocorrendo nas últimas décadas. Como o consumo de feijão nas áreas urbanas representa cerca de $70 \%$ do consumo per capita desse produto nas áreas rurais (ver Tabela 5), o êxodo rural e adoção paulatina de hábitos alimentares urbanos explica parte dessa redução no consumo.

Segundo a Comissão de Financiamento da Produção - CFP (1981), a diferença entre o consumo de feijão no meio rural e urbano não é explicada em termos de diferenças de hábitos alimentares, mas sim por deficiências no sistema de comercialização do produto. Aponta a irregularidade observada em sua oferta como a principal razão de o feijão não ter modernizado sua comercialização e, como conseqüência, ter encarecido o produto para o meio urbano, desestimulando o seu consumo. De acordo com a Figura 3 
pode-se confirmar que os preços do feijão tem se elevado consideravelmente em certos periodos. Porém, não há evidências de que em períodos de preços normais o consumo não tenha se recuperado. Neste caso, a falta de dados a respeito do consumo do produto impossibilita que sejam verificadas as afirmativas feitas nesse trabalho da CFP.

Hoffmann (1995b) também destaca que o longo tempo de cocção necessário para o feijão estar pronto para ser consumido pode ser uma das possíveis causas para a redução em seu consumo. Vale ressaltar que, além do longo tempo de cocção, é necessário limpá-lo, retirando feijões mofados, carunchados e outras impurezas.

\subsection{3 Óleos e gorduras}

A Tabela 20 mostra os resultados do ajuste da poligonal log-log aos dados sobre dispêndio com óleos e gorduras da POF. Não são freqüentes nas áreas urbanas estudadas, valores de $F$ muito baixos como aqueles observados em Brasilia, Curitiba, e Belém, cujos valores não são significativos ao nível de $10 \%$. Nas oito áreas restantes, os valores de $F$ são significativos ao nivel de $5 \%$ e, como conseqüência, encontram-se nesses casos valores elevados do coeficiente de determinação $\left(R^{2}\right)$, o que não ocorreu com as três áreas anteriormente citadas.

Os valores mais altos do coeficiente de variação $(\mathrm{CV})$ são encontrados em Brasilia e Belém, 7,5\% e 6,9\%, respectivamente. Nas demais áreas, seu valor está abaixo ou muito próximo aos $5 \%$, indicando um bom ajustamento.

As estimativas da elasticidade-renda da despesa com óleos e gorduras apresentam um comportamento diferente do que foi observado para o arroz e o feijão. São crescentes entre o primeiro e segundo estratos e decrescentes entre o segundo e terceiro estratos, sugerindo que, caso os rendimentos da população se elevem, as classes de renda agrupadas no segundo estrato aumentarão suas despesas com óleos e gorduras mais do que aquelas agrupadas no primeiro estrato. 
TABELA 20 - Coeficientes de Elasticidade-renda da despesa per capita com óleos e gorduras nos estratos considerados para 11 áreas urbanas do Brasil, obtidos através do ajustamento de uma poligonal log-log de acordo com dados da POF (1987-88).

\begin{tabular}{lccccccccc}
\hline & Esquema de & $R^{2}$ & $C V$ & \multicolumn{2}{c}{ Elasticidade do estrato } & Elasticidade & Valor \\
Área urbana & agrupamento & & $\%$ & I & II & III & média $^{1}$ & de $F$ \\
\hline Goiânia & $3-1-6$ & 0,73 & 3,5 & 0,314 & 1,547 & $-0,114$ & 0,085 & $5,51^{* *}$ \\
Brasilia & $6-3-1$ & 0,51 & 7,5 & 0,075 & 0,118 & 0,405 & 0,174 & 2,05 \\
Porto Alegre & $8-1-1$ & 0,97 & 0,7 & $-0,053^{* *}$ & $3,100^{* *}$ & $-1,503^{* *}$ & 0,192 & $74,45^{* *}$ \\
Curitiba & $5-1-4$ & 0,19 & 3,9 & 0,027 & 0,636 & $-0,089$ & 0,031 & 0,48 \\
São Paulo & $5-2-3$ & 0,85 & 3,1 & 0,184 & 0,326 & 0,178 & 0,220 & $11,63 *$ \\
Rio de Janeiro & $7-1-2$ & 0,90 & 3,5 & $0,173^{* *}$ & 1,253 & 0,172 & 0,283 & $17,60^{* *}$ \\
Belo Horizonte & $6-1-3$ & 0,78 & 3,0 & 0,068 & $0,892^{*}$ & $-0,096^{*}$ & 0,158 & $6,95 *$ \\
Salvador & $1-3-6$ & 0,71 & 5,0 & 0,195 & 0,435 & 0,048 & 0,177 & $4,96^{* *}$ \\
Recife & $3-2-5$ & 0,82 & 5,4 & 0,164 & 0,385 & 0,196 & 0,217 & $9,43 * *$ \\
Fortaleza & $6-2-2$ & 0,98 & 1,5 & $0,159^{* *}$ & $0,634^{* *}$ & $-0,092^{* *}$ & 0,206 & $113,02^{* *}$ \\
Belém & $8-1-1$ & 0,59 & 6,9 & 0,044 & 1,374 & $-0,260$ & 0,141 & 2,93 \\
\hline
\end{tabular}

Fonte: Dados da IBGE $(1991, \mathrm{n} .1)$ processados pelo autor.

${ }^{1}$ A elasticidade média geral ponderada para as 11 áreas urbanas é de 0,214.

No primeiro estrato o teste $t$ refere-se à hipótese de que a elasticidade-renda é igual a zero. No segundo e terceiro estratos, o teste $t$ refere-se à hipótese de que a diferença da elasticidade do estrato em relação à do estrato anterior é igual a zero.

** Significativo ao nivel de $5 \%$.

* Significativo ao nível de $10 \%$.

Os coeficientes de elasticidade-renda encontrados no primeiro estrato são, em geral, maiores do que os do terceiro estrato. Somente em Brasília e Recife esta situação se inverteu. Nota-se, também, que o segundo estrato é composto, com freqüência, por poucas classes de renda, no máximo três. Goiânia, Porto Alegre, Curitiba, Rio de Janeiro, Belo Horizonte e Belém têm seu segundo estrato composto por apenas uma classe de 
renda e São Paulo e Fortaleza têm duas. Essa distribuição das classes sugere que uma divisão das mesmas em apenas dois estratos poderia se mostrar adequada.

Os coeficientes de elasticidade-renda do dispêndio com óleos e gorduras obtidos por Furtuoso (1981) a partir dos dados do ENDEF para o estado de São Paulo mostraram-se decrescentes entre o primeiro e segundo estratos e crescentes entre o segundo e terceiro estratos. Os valores obtidos foram 0,50, $-0,04$ e 0,04 para o primeiro, segundo e terceiro estratos, respectivamente. Perez (1973), obteve coeficientes de elasticidade-renda decrescentes para o dispêndio com óleo no município de Piracicaba, sendo que os valores obtidos foram $1,03,0,09$ e $-0,04$.

Em Porto Alegre, Fortaleza e Belo Horizonte, as variações entre os três estratos são estatisticamente significativas pelo teste $t$, ao nível de $5 \%$ nas duas primeiras áreas e ao nível de $10 \%$ na última. Nas demais áreas, as variações entre os estratos não foram significativas.

Em Goiânia e Curitiba, a elasticidade-renda média apresenta seus menores valores, 0,085 e 0,031, respectivamente. Nas demais áreas, a elasticidade média se mantém acima de 0,100 , atingindo seu valor mais elevado no Rio de Janeiro com 0,283. A elasticidade média geral, ponderada para as onze áreas urbanas é 0,214. Utilizando dados fornecidos pelo ENDEF referentes a 1974/75, para o Brasil como um todo, Melo (1988) obteve o valor zero para o coeficiente médio da elasticidade-renda do dispêndio com óleos e gorduras, valor inferior ao resultado obtido neste trabalho.

Na Figura 4 está representada a variação dos preços médios dos óleos de soja, arroz e algodão no período de 1974 a 1988. Predomina em quase todo o período da análise, uma tendência de declínio nos preços desses produtos, com exceção apenas do período 1983-85. Em 1988, o preço médio do óleo de soja representava 59\% do preço do ano base. Quando se consideram os valores médios dos períodos nos quais as pesquisas ENDEF e POF foram realizadas, essa redução é de 49\%. Os óleos de arroz e de algodão apresentaram comportamento bastante semelhante ao do óleo de soja, 
dispensando maiores comentários. De forma geral, o comportamento dos preços destes óleos favoreceram o aumento do consumo desses produtos.

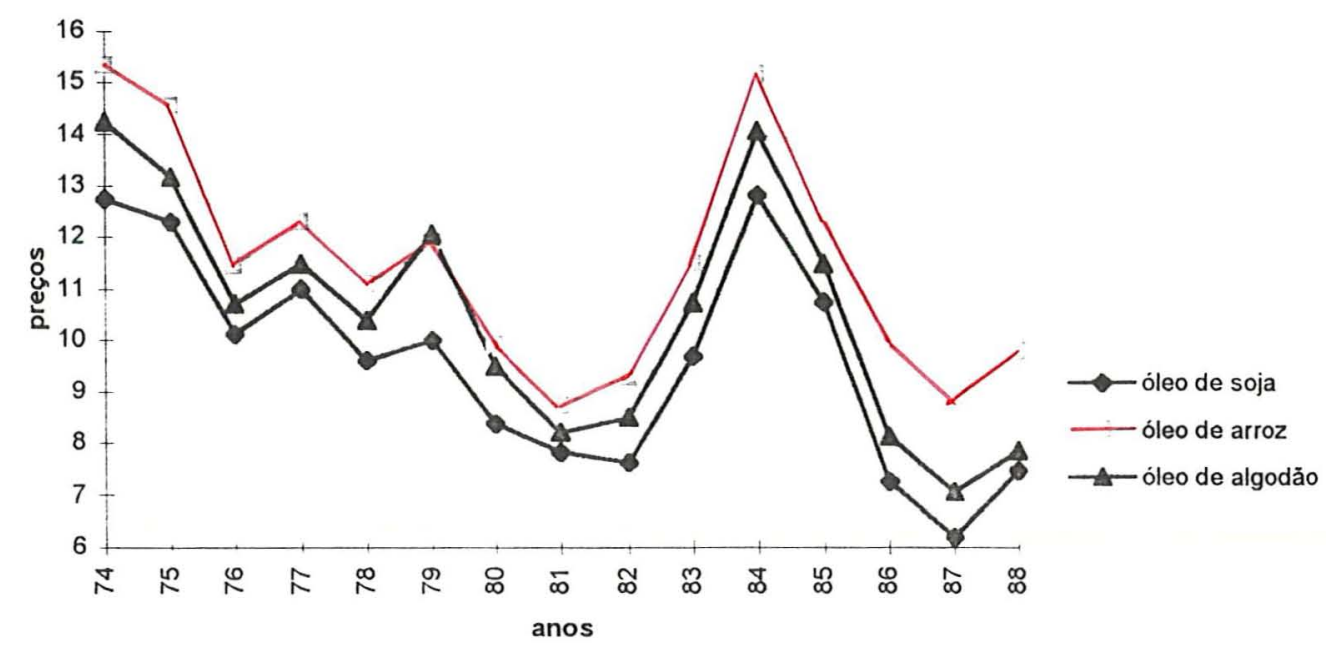

Figura 4 - Preços médios anuais dos óleos de soja, arroz e algodão (lata de 900ml) no varejo da cidade de São Paulo - 1974/88. Em cruzados de março de 1986. Fonte: Dados do IEA (1990) processados pelo autor.

De acordo com a Tabela 16 o consumo anual per capita de óleos e derivados aumentou 1,11\%, entre 1974 e 1988, o que equivale a uma elevação de pouco mais de $100 \mathrm{~g}$ em seu consumo. O óleo de soja, o principal item desse grupo de alimentos, apresentou um aumento em seu consumo de 37,36\% (ver Tabela 16). Este aumento, certamente, foi impulsionado pela redução do preço deste produto durante o período em estudo.

Observa-se, entre 1974/75 e 1987/88, uma redução nas despesas monetárias médias anuais per capita com o grupo dos óleos e gorduras de 68,96\% (ver Tabela 17). O óleo de soja explica parte dessa redução, pois seus preços se reduziram mais de $40 \%$ nesse período.

Tomando o aumento de 32\% ocorrido no PIB per capita entre 1974 e 1988 e considerando que a distribuição da renda tenha se mantido inalterada, obtém-se, a partir da elasticidade média calculada para o grupo dos óleos e gorduras $(0,214)$, um aumento nas despesas com esses produtos de 6,85\%. Este valor, assim como a redução observada 
no preço do óleo de soja, explicam o aumento no consumo de óleos e gorduras entre os anos de 1974 e 1988. Porém, a elevação verificada no consumo ficou aquém do esperado. $E$, como os preços do óleo de soja para esse período também se mostraram favoráveis ao aumento no consumo, deduz-se que está havendo uma mudança nos hábitos alimentares no sentido de reduzir o consumo de óleos e gorduras.

É bastante conhecido que o consumo de óleos e gorduras pode trazer problemas à saúde e, o tímido aumento verificado no seu consumo talvez seja reflexo desse tipo de preocupação. Slaterry \& Randall (1988), citados por Monteiro (1995, p:79), afirmam ser bastante conhecida a associação entre o consumo de gorduras saturadas e a ocorrência de doença coronariana. A obesidade é também problema bastante comum associado ao consumo de gorduras. Faria (1997), citando Burton (1979), afirma que “...a obesidade causada por disfunção endócrina é excepcionalmente rara, sendo a mais comum a obesidade 'familiar' a qual provém essencialmente de fatores ambientais e não hereditários, através da transmissão de hábitos alimentares de uma geração para outra"

A população brasileira passou por um intenso processo de urbanização entre as décadas de 60 e 80 e como o sedentarismo tem predominado, diminui a necessidade do consumo de óleos e gorduras como fonte calórica. A diminuição no consumo de outros alimentos básicos como arroz e feijão influenciam diretamente o consumo de óleos, pois são utilizados em seu cozimento. Como é crescente a intensidade com que esses fatores estão afetando o consumo de óleos e gorduras, e como a busca por uma alimentação mais saudável é uma tendência que deve prevalecer, certamente o consumo desses alimentos continuará crescendo lentamente

\subsubsection{Carne Suína}

Os resultados dos ajustamentos das poligonais log-log aos dados de despesa com carne suína apresentam valores elevados de $F$ em quase todas as áreas urbanas estudadas (Tabela 21). Somente em São Paulo e Porto Alegre os valores de $F$ não são 
significativos ao nivel de $10 \%$ e $5 \%$, respectivamente. Observa-se, também, que nessas duas áreas o coeficiente de determinação $\left(R^{2}\right)$ registra seus menores valores. Nas demais localidades os valores do coeficiente de determinação $\left(R^{2}\right)$ estão sempre acima de 0,70 .

TABELA 21 - Coeficientes de Elasticidade-renda da despesa per capita com carne suína nos estratos considerados para 11 áreas urbanas do Brasil, obtidos através do ajustamento de uma poligonal log-log de acordo com dados da POF (198788).

\begin{tabular}{|c|c|c|c|c|c|c|c|c|}
\hline \multirow[b]{2}{*}{ Área urbana } & \multirow{2}{*}{$\begin{array}{l}\text { Esquema de } \\
\text { agrupamento }\end{array}$} & \multirow[t]{2}{*}{$R^{2}$} & \multirow{2}{*}{$\begin{array}{l}C V \\
\%\end{array}$} & \multicolumn{3}{|c|}{ Elasticidade do estrato } & \multirow{2}{*}{$\begin{array}{c}\text { Elasticidade } \\
\text { média }^{1}\end{array}$} & \multirow{2}{*}{$\begin{array}{l}\text { Valor } \\
\text { de } F\end{array}$} \\
\hline & & & & I & II & III & & \\
\hline Goiânia & $3-2-5$ & 0,88 & 6,2 & $0,817^{* *}$ & 0,260 & 0,192 & 0,309 & $15,37^{* *}$ \\
\hline Brasilia & $1-8-1$ & 0,93 & 12,7 & $9,551^{* *}$ & $0,759^{* *}$ & $-1,321^{* *}$ & 0,442 & $26,65^{* *}$ \\
\hline Porto Alegre & $7-1-2$ & 0,64 & 9,3 & $-0,156$ & $3,293^{\text {** }}$ & $-0,390^{\circ *}$ & 0,049 & $3,58^{*}$ \\
\hline Curitiba & $3-1-6$ & 0,75 & 5,2 & $-0,810^{* *}$ & $2,799^{* *}$ & $0,150^{*}$ & 0,103 & $5,91^{* *}$ \\
\hline São Paulo & $6-2-2$ & 0,09 & 10,0 & 0,160 & 0,029 & $-0,091$ & 0,064 & 0,19 \\
\hline Rio de Janeiro & $2-7-1$ & 0,77 & 9,2 & 0,451 & 0,377 & 0,280 & 0,365 & $6,70^{* *}$ \\
\hline Belo Horizonte & $7-2-1$ & 0,82 & 8,3 & 0,208 & 1,720 & $-0,252$ & 0,431 & $9,10^{* *}$ \\
\hline Salvador & $2-3-5$ & 0,80 & 17,3 & 1,161 & 1,005 & $-0,112^{*}$ & 0,394 & $8,17^{* *}$ \\
\hline Recife & $6-3-1$ & 0,75 & 25,1 & $0,621^{*}$ & 0,572 & 0,145 & 0,508 & $5,85^{* *}$ \\
\hline Fortaleza & $1-6-3$ & 0,96 & 4,5 & $2,017^{* *}$ & $0,366^{* *}$ & $-0,407^{* *}$ & 0,289 & $48,5^{* *}$ \\
\hline Belém & $1-8-1$ & 0,90 & 27,6 & $8,414^{* *}$ & $0,537^{* *}$ & $-0,269$ & 0,436 & $17,76^{* *}$ \\
\hline
\end{tabular}

Fonte: Dados da IBGE $(1991, \mathrm{n} .1)$ processados pelo autor.

${ }^{1}$ A elasticidade média geral ponderada para as 11 áreas urbanas é de 0,228.

No primeiro estrato o teste $t$ refere-se à hipótese de que a elasticidade-renda é igual a zero. No segundo e terceiro estratos, o teste $t$ refere-se à hipótese de que a diferença da elasticidade do estrato em relação à do estrato anterior é igual a zero.

** Significativo ao nível de $5 \%$.

* Significativo ao nivel de $10 \%$. 
Em quase todas as regressões, o coeficiente de variação (CV) apresenta valores bastante elevados, mantendo-se acima de 5\%. Os maiores valores são registrados em Recife, 25,1\%, Belém, 27,6\% e Salvador, 17,3\%. Estes resultados não caminham na mesma direção daqueles obtidos no coeficientes de determinação $\left(R^{2}\right)$, pois indicam uma variação residual grande em relação ao valor médio da variável dependente.

Os coeficientes de elasticidade-renda da despesa com carne suína são, em geral, decrescentes do primeiro para o terceiro estrato. Em Porto Alegre, Curitiba e Belo Horizonte os coeficientes de elasticidade apresentam-se crescentes do primeiro para o segundo estrato e decrescentes entre o segundo e o terceiro estrato. Porto Alegre e Curitiba são as únicas áreas urbanas que apresentam sinais negativos nos coeficientes de elasticidade do primeiro estrato. No segundo estrato, todos os coeficientes apresentam sinais positivos. Somente Goiânia, Curitiba, Rio de Janeiro e Recife apresentam sinais positivos nos coeficientes do terceiro estrato.

Em Brasilia, Porto Alegre, Curitiba, Salvador, Fortaleza e Belém, as variações são estatisticamente significativas pelo teste $t$ entre ao menos dois dos estratos considerados, a um nível de $5 \%$ na maior parte dos casos. Nas demais áreas as variações não são estatisticamente significativas.

Vale ressaltar que os coeficientes bastante elevados observados no primeiro estrato das áreas urbanas de Brasília, Belém e Fortaleza se devem ao fato desses estratos serem compostos apenas por uma classe de renda (a mais baixa). A pouca importância desses resultados isolados é evidenciada pelo valor da elasticidade média dessas áreas, que é bastante semelhante às demais.

Perez (1973) obteve para o município de Piracicaba coeficientes de elasticidade-renda do dispêndio com carne suína decrescentes em relação a renda. Nos três estratos considerados, os valores obtidos foram maiores do que 1 .

Em Porto Alegre, São Paulo e Curitiba os coeficientes médios de elasticidaderenda da despesa com carne suina apresentam os valores mais baixos, 0,049, 0,064 e 
0,103 , respectivamente. Nas demais áreas urbanas, a elasticidade média oscila em torno de 0,400 e atinge o valor máximo em Recife com 0,508.

O coeficiente médio de elasticidade-renda observado em Porto Alegre mostra que, ao se elevar a renda não haverá grande aumento no consumo de carne suína. Tal resultado é bastante coerente, pois o consumo de carnes, em geral, é tradicionalmente elevado no Rio Grande do Sul. Esse comportamento é confirmado nos ítens apresentados a seguir que tratam especificamente do consumo das carnes bovina e de frango.

A elasticidade média geral, ponderada para as dez áreas urbanas, é de 0,228. Este coeficiente é semelhante ao coeficiente médio de elasticidade-renda do dispêndio com carne suína calculado por Melo (1988), 0,29. Este autor utilizou os dados do ENDEF referentes a $1974 / 75$, para o Brasil como um todo.

A Figura 5 apresenta o comportamento dos preços médios das carnes suína, bovina e de frango no mercado varejista da cidade de São Paulo, entre os anos de $1974 \mathrm{e}$ 1988. O estudo das variações no consumo de carne bovina e de frango serão apresentados a seguir, nos itens 6.2 .5 e 6.2.6, onde também serão discutidos mais detalhadamente o comportamento dos seus preços.

Em 1974, a carne suína era substancialmente mais cara do que a carne bovina ou a de frango. Mas, a partir de 1979 a carne suína passa a apresentar preços muito próximos aos da carne bovina, tornando-se mais competitiva. A carne de frango apresentou em todo o período um comportamento semelhante ao da carne suína embora seus preços médios tenham sido bastante menores do que os da carne suína. Em 1988 o preço da carne de frango representava $56 \%$ do preço da carne suína.

O preço médio da carne suína manteve-se, em todo o período estudado, inferior ao de 1974. Entre 1976 e 1979, observa-se uma tendência de elevação nos preços, mas na primeira metade da década seguinte eles tornaram a baixar, atingindo em 1981 um valor $31 \%$ menor do que o observado em 1974. A partir de 1982, nota-se nova tendência de alta nos preços, atingindo em 1986 o maior valor do período. O preço 
médio de 1988 é $29 \%$ menor do que o valor encontrado em 1974. Considerando os períodos específicos nos quais as pesquisas ENDEF e POF foram realizadas, a redução é de $25 \%$. Com base nessas informações, pode-se afirmar que a variação observada nos preços afetaram positivamente o consumo de carne suína, tal como veremos a seguir.

O consumo de carne suína sofreu pequena alteração entre os anos de 1974/75 e 1987/88. Segundo dados do ENDEF e da POF o seu consumo per capita, nesse período, passou de 2,466 kg para 2,532 kg (ver Tabela 16). As despesas monetárias anuais per capita com carne suína, nesse mesmo período, diminuíram em média 38,36\% (ver Tabela 17).

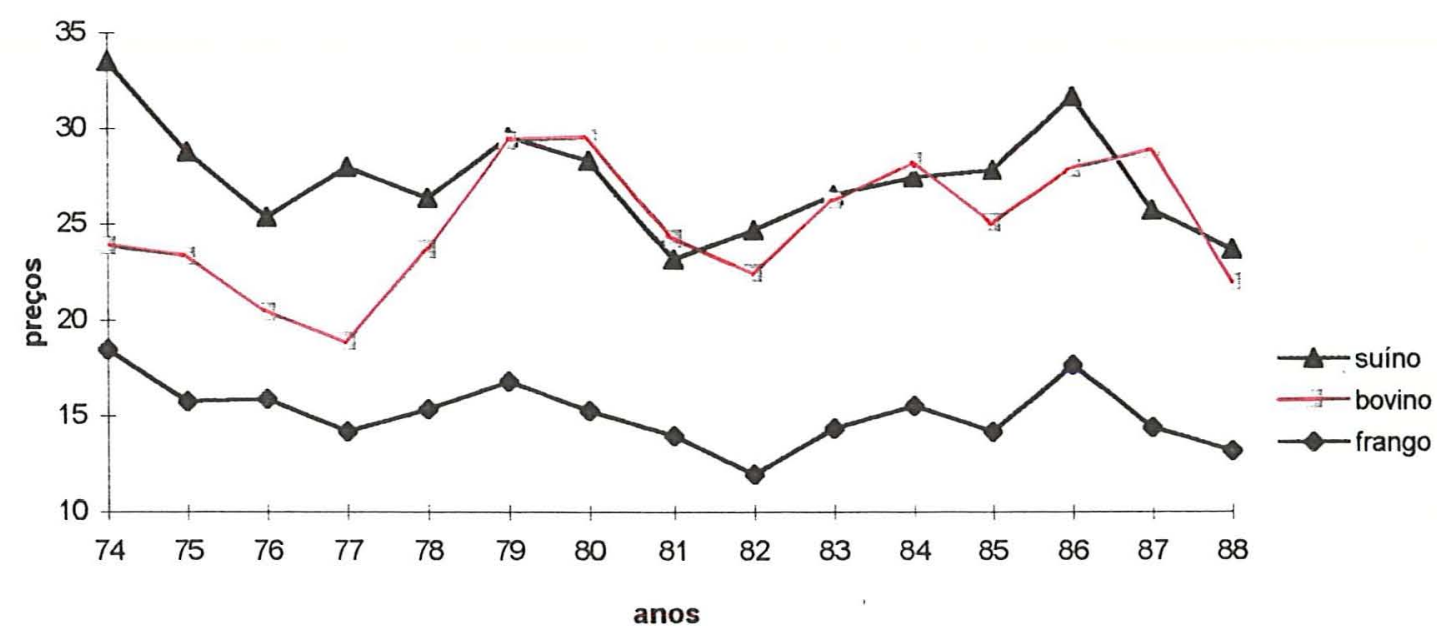

Figura 5 - Preços médios anuais das carnes suína, bovina e de frango (kg) no varejo da cidade de São Paulo -1974/88. Em cruzados de março de 1986.

Fonte: Dados do IEA (1990) processados pelo autor.

O consumo de carne suína representava em 1974/75 cerca de 8,2\% do consumo total dos três tipos de carnes apresentados na Tabela 16. Em 1987/88 esse valor reduziu-se para $7,1 \%$. A carne bovina também teve a sua participação reduzida nesse período, passando de $61,3 \%$ para $51,7 \%$. A carne de frango, ao contrário das outras duas, ampliou sua participação passando de 30,4\% em 1974/75 para 41,2\% em 1987/88.

Segundo Aves \& Ovos ${ }^{3}$ (1993), o valor médio de 1974 e 1975 do consumo per capita de carne suína, bovina e de frango para o Brasil era de 7,1 kg, 15,25 kg e 4,8

${ }^{3}$ Aves \& Ovos cita como fonte desses dados o IBGE/IEA/UBA/APA. 
$\mathrm{kg}$, respectivamente. Em 1987 e 1988 o consumo da carne suína aumentou para 7,5 kg, o consumo da carne bovina reduziu-se para $11,9 \mathrm{~kg}$ e o consumo de frango elevou-se para $12,1 \mathrm{~kg}$.

Através do coeficiente de elasticidade média geral calculado para a carne suína $(0,228)$ pode-se inferir que, mantendo-se inalterada a distribuição da renda, o aumento de $32 \%$ no PIB per capita ocorrido nesse período, resultaria em um aumento de $7,3 \%$ nas despesas com esse produto dos residentes nas áreas urbanas do Brasil. Considerando-se o preço médio da carne suína no período no qual o ENDEF foi realizado ( $\mathrm{R} \$ 7,51)$ e as quantidades fisicas consumidas $(2,466 \mathrm{~kg})$, o efeito da renda promoveria um aumento de $180 \mathrm{~g}$ no consumo.

Com base nessas informações conclui-se que o aumento no consumo da carne suína ocorreu por efeito da renda e dos preços. A redução observada em seus preços tornou a carne suína mais competitiva em relação à carne bovina. Porém, o aumento observado no consumo per capita dessa carne ficou abaixo do valor projetado pelo efeito da renda, mostrando que o seu consumo foi preterido pelo consumo de outro tipo de alimento, possivelmente pela carne de frango.

\subsubsection{Carne bovina}

Na Tabela 22 são apresentados os resultados dos ajustamentos das poligonais $\log -\log$ aos dados de despesa com carne bovina para onze áreas urbanas do Brasil. Em todas as regressões observam-se valores de $F$ muito elevados, todos significativos ao nível de $1 \%$.

O coeficiente de determinação $\left(R^{2}\right)$ assume, em todas as áreas urbanas, valores bastante elevados, sendo que em Porto Alegre encontra-se seu menor valor, 0,87 . Nos demais casos, os valores encontrados estão sempre acima de 0,90 , inclusive com alguns valores muito próximos de 1,00 , indicando que o ajustamento da poligonal aos dados é muito bom 
Os resultados exibidos pelo coeficiente de variação $(\mathrm{CV})$ confirmam o bom ajustamento. Quase todos os seus valores estão abaixo de $3 \%$.

TABELA 22 - Coeficientes de Elasticidade-renda da despesa per capita com carne bovina nos estratos considerados para 11 áreas urbanas do Brasil, obtidos através do ajustamento de uma poligonal log-log de acordo com dados da POF (1987-88).

\begin{tabular}{|c|c|c|c|c|c|c|c|c|}
\hline \multirow[b]{2}{*}{ Área urbana } & \multirow{2}{*}{$\begin{array}{l}\text { Esquema de } \\
\text { agrupamento }\end{array}$} & \multirow[t]{2}{*}{$R^{2}$} & \multirow{2}{*}{$\begin{array}{l}\mathrm{CV} \\
\%\end{array}$} & \multicolumn{3}{|c|}{ Elasticidade do estrato } & \multirow{2}{*}{$\begin{array}{c}\text { Elasticidade } \\
\text { média }^{\mathrm{I}}\end{array}$} & \multirow{2}{*}{$\begin{array}{l}\text { Valor } \\
\text { de } F\end{array}$} \\
\hline & & & & I & II & III & & \\
\hline Goiânia & $1-8-1$ & 0,99 & 1,0 & $0,739^{* *}$ & 0,331 & 0,243 & 0,319 & $137,29^{* *}$ \\
\hline Brasília & $1-8-1$ & 0,99 & 1,3 & $1,202^{*}$ & 0,420 & $0,143^{* *}$ & 0,350 & $139,17^{* *}$ \\
\hline Porto Alegre & $1-8-1$ & 0,87 & 2,3 & 0,828 & 0,291 & $-0,124$ & 0,255 & $13,26^{* *}$ \\
\hline Curitiba & $6-1-3$ & 0,96 & 2,0 & $0,584^{* *}$ & $0,467^{*}$ & $0,252^{* *}$ & 0,419 & $53,22^{\prime * *}$ \\
\hline São Paulo & $1-6-3$ & 0,97 & 1,3 & $1,072^{* *}$ & 0,411 & 0,115 & 0,288 & $66,99^{* *}$ \\
\hline Rio de Janeiro & $6-1-3$ & 0,95 & 3,1 & $0,585^{*}$ & 0,568 & 0,375 & 0,490 & $35,52^{* *}$ \\
\hline Belo Horizonte & $1-8-1$ & 0,98 & 2,3 & $0,910^{* *}$ & 0,608 & 0,214 & 0,530 & $85,60^{* *}$ \\
\hline Salvador & $6-3-1$ & 0,94 & 2,0 & $0,234^{x *}$ & 0,527 & 0,207 & 0,322 & $34,36^{\prime \pi}$ \\
\hline Recife & $2-7-1$ & 0,99 & 1,5 & 0,113 & $0,654^{x \times}$ & $-0,100^{* *}$ & 0,442 & $161,80^{* *}$ \\
\hline Fortaleza & $6-1-3$ & 1,00 & 1,3 & $0,821^{* *}$ & 0,580 & 0,376 & 0,599 & $401,91^{* *}$ \\
\hline Belém & $1-8-1$ & 0,97 & 1,2 & $-0,095$ & 0,431 & $-0,114^{* *}$ & 0,322 & $65,62^{* *}$ \\
\hline
\end{tabular}

Fonte: Dados da IBGE $(1991$, n. 1) processados pelo autor.

${ }^{1}$ A elasticidade média geral ponderada para as 11 áreas urbanas é de 0,373 .

No primeiro estrato o teste $t$ refere-se à hipótese de que a elasticidade-renda é igual a zero. No segundo e terceiro estratos, o teste $t$ refere-se à hipótese de que a diferença da elasticidade do estrato em relação à do estrato anterior é igual a zero.

** Significativo ao nível de $5 \%$.

* Significativo ao nível de $10 \%$.

As estimativas dos coeficientes de elasticidade-renda das despesas com carne bovina decrescem quando aumenta a renda em quase todas as áreas urbanas estudadas. 
Salvador, Recife e Belém foram as exceções, com coeficientes de elasticidade crescentes entre o primeiro e o segundo estrato, onde atingem o valor mais alto, decrescendo entre $o$ segundo e o terceiro estrato.

Brasília e São Paulo apresentaram coeficientes de elasticidade-renda acima de 1 no primeiro estrato. Observa-se, também, que em geral os coeficientes de elasticidade nos três estratos são positivos. Este comportamento não é observado em Porto Alegre e Recife, onde o coeficiente é negativo no terceiro estrato. O mesmo ocorre em Belém, que também apresenta sinal negativo no coeficiente de elasticidade-renda do primeiro estrato.

Brasilia, Curitiba, Recife e Belém apresentam, pelo teste $t$, variações estatisticamente significativas no coeficientes de elasticidade de pelo menos dois dos três estratos considerados, quase sempre ao nível de 5\%. Nas demais áreas, as variações não são estatisticamente significativas. Somente em Porto Alegre, Recife e Belém os coeficientes do primeiro estrato não diferem estatisticamente de zero.

Os coeficientes de elasticidade-renda do dispêndio com carne bovina obtidos por Perez (1973) para o município de Piracicaba não são decrescentes com a elevação da renda como os coeficientes obtidos neste estudo. Eles foram decrescentes entre o primeiro e segundo estratos, passando de 1,66 para 0,47 , mas entre o segundo e terceiro estratos foram crescentes, atingindo o valor 0,72 .

A elasticidade-renda média mostra-se positiva em todas as áreas urbanas estudadas. Seu valor oscila entre 0,200 e 0,400 em Goiânia, Brasilia, Porto Alegre, São Paulo, Salvador e Belém. Entre 0,400 e 0,600 em Curitiba, Rio de Janeiro, Belo Horizonte, Recife e Fortaleza. A elasticidade média geral, ponderada para as 10 áreas urbanas, é 0,373 . Este coeficiente tem valor substancialmente mais baixo do que o coeficiente médio de elasticidade-renda do dispêndio com carne bovina calculado por Melo (1988), 0,99. Este autor utilizou os dados do ENDEF referentes a 1974/75, para o Brasil como um todo. 
Através da Figura 5 pode-se analisar o comportamento dos preços médios da carne bovina, entre 1974 e 1988. No início do período, de 1974 até 1977, os preços apresentaram um movimento declinante, contrastando com a elevação dos preços observados no final dessa década. $\mathrm{Na}$ década de 80 , os preços mantiveram-se, quase sempre, acima do valor inicial (1974). O ano de 1988 apresentou um valor médio $8 \%$ inferior ao de 1974. Mas, quando se consideram especificamente os períodos nos quais as pesquisas ENDEF e POF foram realizadas, observa-se uma elevação nos preços de $5 \%$. Como se pode ver, os preços da carne bovina não estimularam a aquisição do produto, e estão relacionados com a estagnação no seu consumo, como veremos a seguir.

De acordo com a Tabela 16, o consumo anual de carne bovina per capita em $1974 / 75$ era de $18,369 \mathrm{~kg}$ e em 1987/88 passou para $18,325 \mathrm{~kg}$, apresentando uma redução de apenas alguns gramas em seu consumo. De acordo com a Tabela 17, nesse mesmo período, observa-se uma redução de 19,03\% nas despesas com esse produto.

A elasticidade média geral calculada para a carne bovina $(0,373)$ indica que o aumento de $32 \%$ ocorrido no PIB per capita dos brasileiros entre 1974 e 1988 levaria a um aumento de $11,9 \%$ no consumo desse produto desde que a distribuição da renda fosse mantida inalterada. Considerando-se as quantidades fisicas consumidas no período no qual o ENDEF foi realizado $(18,396 \mathrm{~kg})$, esse efeito da renda seria responsável por um aumento no consumo de carne bovina de $2,189 \mathrm{~kg}$. Tal elevação não ocorreu, indicando que pode ter havido um processo de substituição por outro tipo de carne ou mesmo por outro tipo de alimento.

Comparando-se os preços da carne bovina com as demais carnes, observa-se que a carne de frango foi a que apresentou melhor desempenho durante o período de 1974 a 1988. Em 1974/75 ela custava 66\% do preço da carne bovina e em 1987/88 ela passou a custar menos de $50 \%$. Certamente essa foi uma das razões pela qual a carne de frango apresentou elevação em seu consumo per capita. Enquanto isso, a carne suína conseguiu reduzir seus preços a valores próximos aos da carne bovina, tornando-se mais atrativa para os consumidores. 
Pode-se concluir, portanto, que a relativa estagnação no consumo de carne bovina foi causada pelo aumento da competitividade das outras carnes, principalmente a de frango, em razão de terem estabelecido preços mais atrativos. No entanto, como o aumento projetado pela elevação na renda nas despesas per capita com carne bovina não ocorreu, deduz-se que também estão ocorrendo mudanças nos hábitos alimentares, através da substituição no consumo de carnes. Veremos a seguir, no item 6.2.6, que o aumento no consumo de carne de frango é maior do que o efeito renda pode explicar, indicando que houve substituição de outros alimentos por frango.

\subsubsection{Frango}

Os resultados dos ajustamentos das poligonais log-log aos dados de despesa com carne de frango em dez áreas urbanas ${ }^{4}$ do Brasil estão apresentados na Tabela 23. Valores de $F$ significativos ao nível de $5 \%$ são observados em Brasília, Belo Horizonte, Recife e Fortaleza. Conseqüentemente os valores do coeficiente de determinação $\left(R^{2}\right)$ dessas áreas urbanas são os mais altos. Curitiba e Rio de Janeiro apresentam baixos valores do coeficiente de determinação $\left(R^{2}\right)$ e por essa razão seus valores de $F$ são significativos apenas ao nivel de $10 \%$.

Em Goiânia, Porto Alegre, São Paulo e Belém, onde os valores de $F$ não são significativos ao nível de $10 \%$, encontram-se os valores do coeficiente de determinação $\left(R^{2}\right)$ mais baixos. Em contrapartida os valores do coeficiente de variação $(C V)$ estão, em todas as áreas urbanas estudadas, abaixo de $5 \%$.

De maneira semelhante ao que foi observado para os outros dois tipos de carne, discutidos nos ítens 6.2 .4 e 6.2 .5 , os coeficientes de elasticidade-renda da despesa com carne de frango apresentam-se decrescentes com a elevação da renda. Belém foi a única exceção, apresentando coeficientes de elasticidade-renda crescentes entre os estratos. Todos os coeficientes de elasticidade-renda do primeiro e segundo estratos mostram-se positivos. Apenas em Curitiba o coeficiente de elasticidade foi maior do que

\footnotetext{
${ }^{4}$ Nenhum dos esquemas de agrupamento obtidos para a área urbana de Salvador apresentou resultados satisfatórios. Portanto não foram apresentados.
} 
1. No terceiro estrato coeficientes negativos foram encontrados somente em Porto Alegre, Curitiba, São Paulo e Recife.

TABELA 23 - Coeficientes de Elasticidade-renda da despesa per capita com frango nos estratos considerados para 10 áreas urbanas do Brasil, obtidos através do ajustamento de uma poligonal log-log de acordo com dados da POF (198788).

\begin{tabular}{lccccccccc}
\hline & Esquema de & $R^{2}$ & $C V$ & \multicolumn{2}{c}{ Elasticidade do estrato } & \multicolumn{2}{c}{ Elasticidade } & Valor \\
Área urbana & agrupamento & & $\%$ & I & II & III & média $^{l}$ & de $F$ \\
\hline Goiânia & $2-1-7$ & 0,59 & 4,6 & 0,517 & 0,474 & 0,038 & 0,146 & 2,38 \\
Brasilia & $2-1-7$ & 0,91 & 1,9 & 0,662 & 0,229 & 0,116 & 0,172 & $20,65^{* *}$ \\
Porto Alegre & $6-3-1$ & 0,55 & 2,1 & 0,133 & 0,055 & $-0,340$ & 0,066 & 2,49 \\
Curitiba & $1-5-4$ & 0,69 & 3,0 & $1,487^{*}$ & 0,135 & $-0,081$ & 0,071 & $4,51^{*}$ \\
São Paulo & $7-2-1$ & 0,27 & 3,6 & 0,123 & 0,054 & $-0,077$ & 0,081 & 0,74 \\
Rio de Janeiro & $1-5-4$ & 0,67 & 3,7 & 0,218 & 0,196 & 0,144 & 0,174 & $4,05^{*}$ \\
Belo Horizonte & $2-1-7$ & 0,83 & 2,6 & $0,529^{* *}$ & 0,250 & 0,076 & 0,155 & $9,98^{* *}$ \\
Recife & $6-2-2$ & 0,85 & 1,6 & $0,185^{* *}$ & 0,056 & $-0,104$ & 0,119 & $11,42^{* *}$ \\
Fortaleza & $1-2-7$ & 0,92 & 1,4 & $0,601^{* *}$ & 0,248 & 0,027 & 0,156 & $22,15^{* *}$ \\
Belém & $5-2-3$ & 0,45 & 2,5 & 0,038 & 0,075 & 0,105 & 0,064 & 1,66 \\
\hline
\end{tabular}

Fonte: Dados da IBGE $(1991$, n.1) processados pelo autor.

${ }^{1}$ A elasticidade média geral ponderada para as 10 áreas urbanas é de 0,117 .

No primeiro estrato o teste $t$ refere-se à hipótese de que a elasticidade-renda é igual a zero. No segundo e terceiro estratos, o teste $t$ refere-se à hipótese de que a diferença da elasticidade do estrato em relação à do estrato anterior é igual a zero.

"* Significativo ao nível de $5 \%$.

* Significativo ao nível de $10 \%$.

Em nenhuma das áreas urbanas estudadas as variações entre os coeficientes dos três estratos considerados são estatisticamente significativas pelo teste $t$. Somente em 
Curitiba, Belo Horizonte, Recife e Fortaleza os coeficientes do primeiro estrato são estatisticamente diferentes de zero.

Perez (1973), estudando o consumo de alimentos para o município de Piracicaba, também obteve coeficientes de elasticidade-renda do dispêndio com frango decrescentes com a elevação da renda. Os valores obtidos, 3,36, 1,96 e 0,41 , são substancialmente maiores do que aqueles obtidos no presente estudo.

As estimativas da elasticidade-renda média da despesa com frango são, geralmente, baixas. O menor valor foi observado em Belém, 0,064, e o maior foi observado no Rio de Janeiro, 0,174. Curitiba, São Paulo e Belém apresentaram elasticidades médias muito próximas de zero. A elasticidade média geral, ponderada para as dez áreas urbanas, é 0,117. Melo (1988), utilizando dados fornecidos pelo ENDEF referentes a 1974/75, para o Brasil como um todo, obteve um valor substancialmente maior para o coeficiente médio da elasticidade-renda do dispêndio com carne de frango: 0,72 .

Segundo os valores apresentados na Tabela 16, a POF (1987/88) registra um aumento no consumo de carne de frango, em relação ao ENDEF (1974/75), de 59,76\%, ou $5,455 \mathrm{~kg}$. Esse aumento no consumo não se reflete em elevação das despesas com o consumo de frango que, pelo contrário, reduziram-se em 2,02\% (ver Tabela 17).

Os preços médios da carne de frango no varejo da cidade de São Paulo, representados na Figura 5, mantiveram-se abaixo do valor observado em 1974. Nos três anos subseqüentes a 1974 há uma redução nos preços, mas em 1978 e 1979 ocorre nova elevação. A partir do final da década de 70, os preços tornaram a cair, atingindo em 1982 o valor mais baixo do período. A partir de 1983, os preços novamente se elevam, atingindo em 1988 um valor $29 \%$ menor do que em 1974. Quando se consideram os períodos específicos nos quais as pesquisas ENDEF e POF foram realizadas essa redução é de $23 \%$ 
Utilizando-se o coeficiente de elasticidade média geral de 0,117 calcula-se que o aumento de $32 \%$ observado no PIB per capita dos brasileiros geraria uma elevação de $3,74 \%$ nas despesas com o consumo de carne de frango, considerando que a distribuição da renda tenha se mantido inalterada. Tomando a quantidade média consumida por comensal-dia registrada no ENDEF $(9,129 \mathrm{~kg})$, esse efeito da renda seria responsável por um aumento de apenas $341 \mathrm{~g}$ no consumo de carne de frango. No entanto, esse valor é muito pequeno frente à variação que houve no período. Para a carne bovina obteve-se um resultado inverso, ou seja, a elasticidade média projetou um grande aumento nas despesas com o produto, mas isso não ocorreu. Com a carne suína observa-se um processo semelhante, embora o aumento de consumo projetado pelo efeito da renda seja bem menor. Esses resultados indicam que houve substituição da carne suína e bovina por carne de frango.

Em relação às carnes suína e bovina, a carne de frango apresenta, além do melhor preço, outras vantagens que são discutidas no trabalho de Silva \& Fabrini Filho (1994). Estes autores constataram um aumento no consumo de carne de frango entre as décadas de 70 e 80 e, também, consideraram que isso ocorreu em função dos preços e do aumento no poder de compra dos brasileiros, mas também enumeram outros fatores: o marketing feito nesse período, a uniformidade do produto derivado do frango, a praticidade, o baixo nivel de lipídios, o fato de possuírem ácidos graxos não saturados e a inexistência de períodos sazonais de produção.

Segundo Senauer et al. (1993), o consumo de aves na América do Norte se elevou em $65,2 \%$ entre 1976 e 1989 , enquanto o consumo de carne bovina diminuiu $26,7 \%$. Nesse período o consumo de aves foi beneficiado por seus preços terem se mantido menores que os da carne bovina, por ser considerado mais saudável do que o consumo de carne bovina e pela utilização de novas formas de comercialização 


\subsubsection{Frutas}

$\mathrm{Na}$ Tabela 24 encontram-se os resultados dos ajustamentos de poligonais loglog aos dados de despesa com frutas para dez áreas urbanas ${ }^{5}$ do Brasil. Para todas as regressões são encontrados valores elevados de $F$, sendo, em todos os casos, significativos ao nível de $1 \%$. Conseqüentemente, os valores exibidos pelo coeficiente de determinação $\left(R^{2}\right)$ foram muito elevados, com o menor valor em Curitiba $(0,94)$.

O coeficiente de variação $(C V)$ apresenta valores sempre abaixo de $4 \%$ e o coeficiente de determinação $\left(R^{2}\right)$ apresenta valores bastante próximos de 1 , indicando boa qualidade no ajustamento da poligonal aos dados.

Apenas Brasília, Recife, Fortaleza, Belém apresentam coeficientes de elasticidade-renda decrescentes com a elevação da renda. Nas demais áreas, a elasticidade é crescente entre o primeiro e segundo estratos e decrescente entre o segundo e terceiro. Todos os coeficientes do primeiro e segundo estratos são positivos. No terceiro estrato, apenas Goiânia, Porto Alegre e Curitiba possuem sinais negativos. Pode-se notar, também, que na maioria dos casos, o terceiro estrato é formado por apenas uma classe de renda.

Goiânia, Porto Alegre, São Paulo, Rio de Janeiro e Belo Horizonte apresentam, pelo teste $t$, variações estatisticamente significativas entre os coeficientes dos três estratos considerados, ao nivel de $5 \%$, na maioria dos casos. Em Fortaleza, as variações foram estatisticamente significativas apenas entre o segundo e terceiro estratos. Nas demais áreas, as diferenças não são estatisticamente significativas. Somente em São Paulo, Rio de Janeiro e Belém os coeficientes do primeiro estrato não diferem estatisticamente de zero.

Os coeficientes de elasticidade-renda da despesa com frutas para o município de Piracicaba, calculados por Perez (1973), mostraram-se decrescentes entre o primeiro e

\footnotetext{
${ }^{5}$ Nenhum dos esquemas de agrupamento obtidos para a área urbana de Salvador apresentou resultados satisfatórios, deixando de ser apresentados.
} 
segundo estratos e crescentes entre o segundo e terceiro estratos. Os valores obtidos para o primeiro, segundo e terceiro estratos foram 2,57, $-0,05$ e 0,69 , respectivamente. Furtuoso (1981) calculou os coeficientes de elasticidade-renda do dispêndio com frutas com base nos dados do ENDEF para o estado de São Paulo. Os coeficientes se mostraram decrescentes com a elevação da renda, sendo que os valores obtidos foram $1,47,0,74$ e 0,45

TABELA 24 - Coeficientes de Elasticidade-renda da despesa per capita com frutas nos estratos considerados para 10 áreas urbanas do Brasil, obtidos através do ajustamento de uma poligonal log-log de acordo com dados da POF (198788).

\begin{tabular}{lccccccccc}
\hline & Esquema de & $R^{2}$ & $C V$ & \multicolumn{2}{c}{ Elasticidade do estrato } & Elasticidade & Valor \\
Área urbana & agrupamento & & $\%$ & I & II & II & média $^{1}$ & de $F$ \\
\hline Goiânia & $8-1-1$ & 0,99 & 2,4 & $0,628^{* *}$ & $1,923^{*}$ & $-0,181^{* *}$ & 0,545 & $138,83^{* *}$ \\
Brasilia & $6-3-1$ & 0,96 & 3,7 & $0,598^{* *}$ & 0,575 & 0,432 & 0,525 & $50,15^{* *}$ \\
Porto Alegre & $7-2-1$ & 0,96 & 2,3 & $0,301^{* *}$ & $1,409^{* *}$ & $-0,926^{* *}$ & 0,420 & $42,49^{* *}$ \\
Curitiba & $8-1-1$ & 0,94 & 4,0 & $0,520^{* *}$ & 1,838 & $-0,079$ & 0,548 & $32,93^{* *}$ \\
São Paulo & $4-3-3$ & 0,96 & 2,0 & 0,203 & $0,802^{* *}$ & $0,158^{* *}$ & 0,402 & $52,26^{* *}$ \\
Rio de Janeiro & $3-6-1$ & 0,98 & 2,6 & 0,259 & $0,798^{* *}$ & $0,018^{* *}$ & 0,535 & $86,59^{* *}$ \\
Belo Horizonte & $4-5-1$ & 0,98 & 2,6 & $0,467^{* *}$ & $0,885^{* *}$ & $0,076^{* *}$ & 0,607 & $115,29^{* *}$ \\
Recife & $7-2-1$ & 0,99 & 2,4 & $0,627^{* *}$ & 0,538 & 0,381 & 0,552 & $141,62^{* *}$ \\
Fortaleza & $4-5-1$ & 0,99 & 1,8 & $0,804^{* *}$ & 0,691 & $0,021^{* *}$ & 0,575 & $334,33^{* *}$ \\
Belém & $1-6-3$ & 0,97 & 3,7 & 0,936 & 0,650 & 0,503 & 0,585 & $55,33^{* * *}$ \\
\hline
\end{tabular}

Fonte: Dados da IBGE (1991, n. 1) processados pelo autor.

1 A elasticidade média geral ponderada para as 11 áreas urbanas é de 0,473 .

No primeiro estrato o teste $t$ refere-se à hipótese de que a elasticidade-renda é igual a zero. No segundo e terceiro estratos, o teste $t$ refere-se à hipótese de que a diferença da elasticidade do estrato em relação à do estrato anterior é igual a zero.

** Significativo ao nível de $5 \%$.

* Significativo ao nível de $10 \%$. 
São Paulo e Porto Alegre apresentam os menores valores do coeficiente de elasticidade-renda médio, 0,402 e 0,420, respectivamente. Nas localidades restantes os coeficientes estiveram sempre acima de 0,500 e atingiram valor máximo em Belo Horizonte, com 0,607. A elasticidade média geral, ponderada para as onze áreas urbanas, é de 0,473. Melo (1988), utilizando dados fornecidos pelo ENDEF referentes a 1974/75, para o Brasil como um todo, obteve um valor cerca de duas vezes maior para o coeficiente médio da elasticidade-renda do dispêndio com frutas: 1,28.

A Tabela 16 mostra que o consumo per capita de frutas aumentou $26,84 \%$ no período de cerca de 12 anos que separa as pesquisas ENDEF da POF, correspondendo a um aumento de 10,182 $\mathrm{kg}$. Esse aumento resultou, como se pode ver na Tabela 17, numa elevação de $54,11 \%$ nas despesas com frutas.

As Figuras 6 e 7 apresentam as variações nos preços da banana-nanica e da laranja no mercado varejista da cidade de São Paulo de 1974 a 1988. Em 1975 e 1976 os preços médios da banana nanica foram superiores ao de 1974; o mesmo se observou entre 1984 e 1987. Entre 1977 e 1983 os preços da banana-nanica mantiveram-se abaixo daquele observado em 1974. Em 1988 a banana-nanica custou cerca de $4 \%$ mais barato do que em 1974. E, quando se consideram os períodos específicos nos quais as pesquisas ENDEF e POF foram realizadas, observa-se uma elevação nos preços de $1 \%$.

Durante todo o período de análise, os preços da laranja apresentaram grandes variações, sendo que até 1983 prevaleceu uma tendência declinante nos preços. Em 1977, os preços variaram positivamente, atingindo um valor 5\% maior do que o de 1974 . Observa-se em 1983 o menor valor do período, 28\% menor do que no ano base. A partir de 1984 os preços se elevaram, atingindo em 1988 um valor $27 \%$ maior do que em 1974. Porém, quando se consideram os preços médios dos períodos específicos nos quais as pesquisas ENDEF e POF foram realizadas esse aumento é de 54\%. 


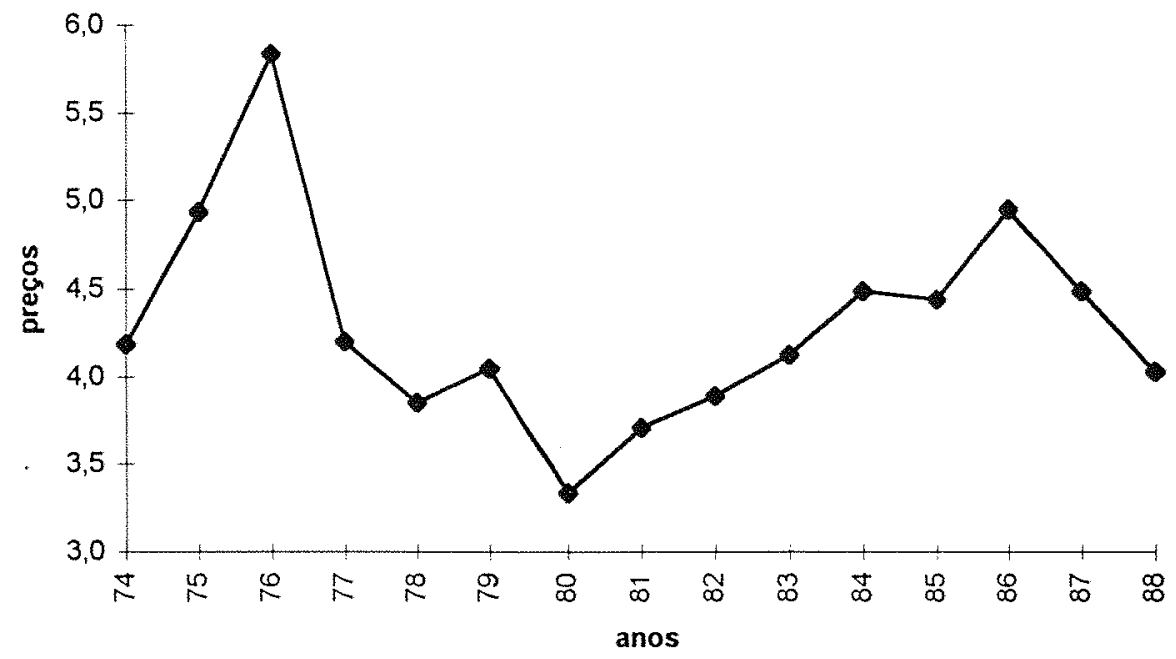

Figura 6 - Preços médios anuais da banana-nanica (dz) no varejo da cidade de São Paulo - 1974/88. Em cruzados de março de 1986.

Fonte: Dados do IEA (1990) processados pelo autor.

O somatório do consumo per capita de banana e laranja é superior a $50 \%$ do total de consumo de frutas nos dois períodos representados pelo ENDEF e pela POF (ver Tabela 16). Os preços médios do limão e do mamão, que também são produtos de grande importância no item frutas, apresentaram uma diminuição de 4\% e 18\%, respectivamente, no mercado varejista da cidade de São Paulo (IEA, 1990) entre os anos de 1974 e 1988.

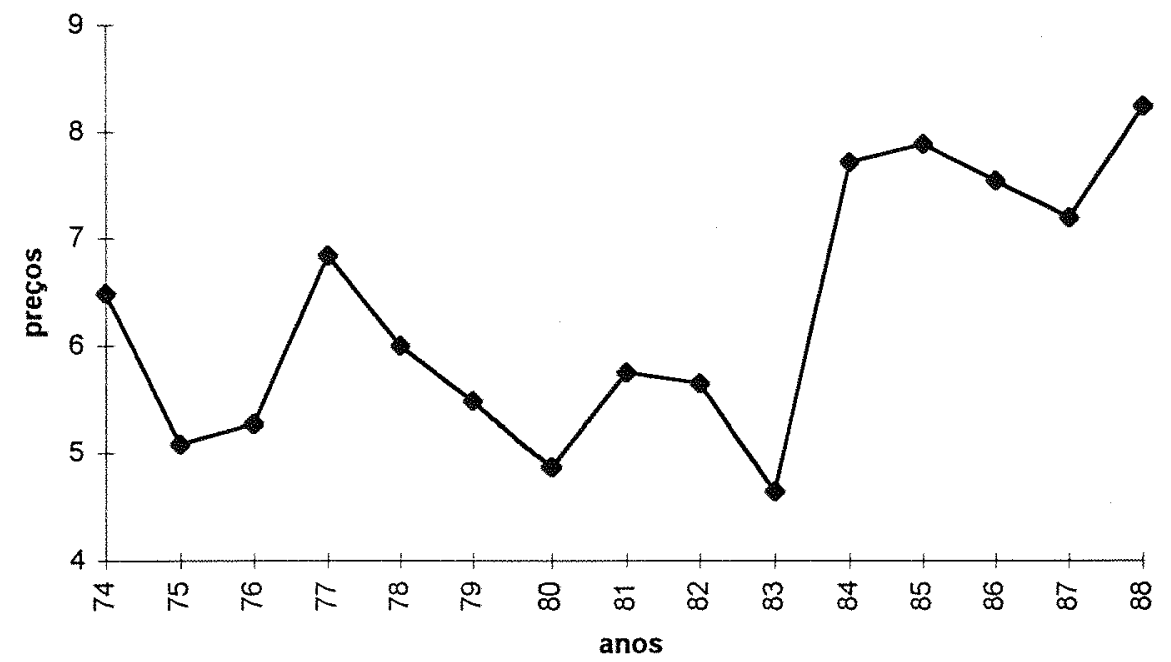

Figura 7 - Preços médios anuais da laranja (dz) no varejo da cidade de São Paulo 1974/88. Em cruzados de março de 1986.

Fonte: Dados do IEA (1990) processados pelo autor. 
Tasco \& Menegário (1992) constataram que entre 1974/75 e 1987/88 houve diversificação no consumo de frutas, com redução no consumo de laranja e banana e aumento no consumo de mamão, manga, abacaxi e maçã.

Com base nesses dados pode-se afirmar que os preços médios das principais frutas incluídas nesse item não influenciaram positivamente no aumento de consumo desses alimentos.

A partir do valor da elasticidade média geral das despesas com frutas $(0,473)$ calcula-se, em razão da elevação de $32 \%$ no PIB per capita entre 1974 e 1988, um aumento de $15,14 \%$ nas despesas com esses produtos, desde que a distribuição da renda tenha se mantido inalterada. Considerando a quantidade média consumida por comensaldia registrada no ENDEF $(37,934 \mathrm{~kg})$, esse efeito da renda corresponde a um aumento de $5,743 \mathrm{~kg}$ no consumo de frutas. Portanto, o efeito da renda explica $56,4 \%$ do aumento observado no consumo de frutas.

Como os preços das frutas não se comportaram de forma favorável ao aumento do seu consumo e o efeito da renda explica apenas $56,4 \%$ da elevação observada no consumo desse grupo de alimentos, considera-se que as mudanças nos hábitos alimentares também são responsáveis pela elevação no consumo desse tipo de produto.

\subsubsection{Legumes e verduras}

Os elevados valores de $F$ encontrados na Tabela 25 mostram que há boa qualidade no ajustamento das poligonais log-log aos dados de despesa com legumes e verduras. Em todos os casos os valores de $F$ mostram-se significativos ao nível de $1 \%$. Conseqüentemente, o coeficiente de determinação $\left(R^{2}\right)$ apresenta valores muito elevados, sendo o menor deles $(0,93)$ observado em Porto Alegre. O coeficiente de variação $(\mathrm{CV})$, sempre inferior a 4\%, também mostra um bom ajustamento da regressão aos dados. 
TABELA 25 - Coeficientes de Elasticidade-renda da despesa per capita com legumes e verduras nos estratos considerados para 11 áreas urbanas do Brasil, obtidos através do ajustamento de uma poligonal log-log de acordo com dados da POF (1987-88).

\begin{tabular}{|c|c|c|c|c|c|c|c|c|}
\hline \multirow[b]{2}{*}{ Área urbana } & \multirow{2}{*}{$\begin{array}{l}\text { Esquema de } \\
\text { agrupamento }\end{array}$} & \multirow[t]{2}{*}{$R^{2}$} & \multirow{2}{*}{$\begin{array}{l}C V \\
\%\end{array}$} & \multicolumn{3}{|c|}{ Elasticidade do estrato } & \multirow{2}{*}{$\begin{array}{c}\text { Elasticidade } \\
\text { média }^{1}\end{array}$} & \multirow{2}{*}{$\begin{array}{l}\text { Valor } \\
\text { de } F\end{array}$} \\
\hline & & & & I & II & III & & \\
\hline Goiânia & $8-1-1$ & 0,99 & 1,4 & $0,341^{*}$ & $1,501^{* *}$ & $-0,385^{* *}$ & 0,325 & $136,45^{* *}$ \\
\hline Brasilia & $1-8-1$ & 0,95 & 3,7 & 1,395 & 0,447 & 0,128 & 0,365 & $42,13^{* *}$ \\
\hline Porto Alegre & $7-1-2$ & 0,93 & 2,0 & $0,262^{* *}$ & 1,017 & $-0,389^{* *}$ & 0,175 & $27,91^{* *}$ \\
\hline Curitiba & $8-1-1$ & 0.93 & 3,4 & $0,369^{* *}$ & 0,996 & $-0,176$ & 0,342 & $27,93^{* *}$ \\
\hline São Paulo & $6-1-3$ & 0,94 & 2,0 & $0,150^{\circ}$ & $0,900^{*-}$ & $0,117^{* *}$ & 0,274 & $33,65^{* *}$ \\
\hline Rio de Janeiro & $4-4-2$ & 0,98 & 1,8 & $0,268^{* *}$ & 0,478 & 0,250 & 0,352 & $100,34^{* *}$ \\
\hline Belo Horizonte & $8-1-1$ & 0,93 & 3,1 & $0,345^{* *}$ & 1,282 & $-0,662$ & 0,310 & $28,16^{* *}$ \\
\hline Salvador & $4-1-5$ & 0,97 & 1,6 & $0,154^{*}$ & 0,468 & 0,237 & 0,233 & $70,80^{* *}$ \\
\hline Recife & $2-1-7$ & 0,97 & 1,8 & $-0,039$ & $0,505^{*}$ & 0,257 & 0,249 & $69,56^{* *}$ \\
\hline Fortaleza & $5-1-4$ & 0,97 & 3,6 & $0,537^{* *}$ & 0,961 & 0,264 & 0,442 & $69,54^{* *}$ \\
\hline Belém & $5-1-4$ & 0,97 & 2,3 & $0,290^{* *}$ & $1,201^{*}$ & $0,297^{*}$ & 0,353 & $75,3^{* *}$ \\
\hline
\end{tabular}

Fonte: Dados da IBGE (1991, n.1) processados pelo autor.

1 A elasticidade média geral ponderada para as 11 áreas urbanas é de 0,298.

No primeiro estrato o teste $t$ refere-se à hipótese de que a elasticidade-renda é igual a zero. No segundo e terceiro estratos, o teste $t$ refere-se à hipótese de que a diferença da elasticidade do estrato em relação à do estrato anterior é igual a zero.

** Significativo ao nível de $5 \%$.

* Significativo ao nível de $10 \%$

A maior parte dos coeficientes de elasticidade-renda obtidos mostra um comportamento similar ao observado em óleos e gorduras (item 6.2.3), isto é, são crescentes quando se passa do primeiro para o segundo estrato e decrescem quando se passa do segundo para o terceiro. Esse comportamento só não é observado em Brasília, onde as elasticidades mostram-se decrescentes. 
Mesmo que o coeficiente do segundo estrato seja maior do que o dos outros estratos, é esperado que o coeficiente do primeiro estrato seja maior do que o do terceiro. Esse tipo de comportamento é observado para a maioria das áreas urbanas estudadas. Somente em Salvador e Recife isso não ocorreu.

Coeficientes com sinais positivos são maioria no terceiro estrato, mas em Goiânia, Porto Alegre, Curitiba e Belo Horizonte os sinais são negativos. Nota-se que o segundo estrato é composto, freqüentemente, por apenas uma classe de renda. Somente em Brasília e no Rio de Janeiro isso não ocorre.

Em Goiânia, São Paulo e Belém as variações entre os três estratos considerados são estatisticamente significativas pelo teste $t$, ao nível de $5 \%$ nas duas primeiras áreas e a $10 \%$ na última. Em Porto Alegre e Recife, as variações são estatisticamente significativas entre pelo menos dois estratos. Apenas em Brasilia e Recife os coeficientes do primeiro estrato não diferem estatisticamente de zero.

Perez (1973) calculou separadamente os coeficientes de elasticidade-renda das despesas com legumes e das despesas com verduras para o município de Piracicaba. Os coeficientes de elasticidade-renda calculados para o dispêndio com legumes mostraram-se decrescente com a elevação da renda, sendo que os valores obtidos foram $1,46,0,85 \mathrm{e}$ 0,33 . No entanto os coeficientes calculados para o dispêndio com verduras apresentaramse decrescentes entre o primeiro e segundo estratos, passando de 1,32 para 1,04. Entre o segundo e terceiro estratos foram crescentes, atingindo o valor 1,40 .

A partir dos dados do ENDEF para o estado de São Paulo, Furtuoso (1981) calculou os coeficientes de elasticidade-renda do dispêndio com legumes e verduras. Estes se mostraram decrescentes com a elevação da renda, sendo que os valores obtidos foram $0,76,0,46$ e 0,25 .

Os coeficientes de elasticidade média são positivos e maiores do que $0,100 \mathrm{em}$ todas as áreas urbanas estudadas. Em Porto Alegre, São Paulo, Salvador e Recife, os valores oscilam entre 0,100 e 0,300 e nos locais restantes eles estão acima de 0,300, 
porém não alcançam 0,500 . A elasticidade média geral, ponderada para as onze áreas urbanas, é de 0,298. Melo (1988), utilizando dados do ENDEF referentes a 1974/75, para o Brasil como um todo, obteve um valor substancialmente maior para o coeficiente médio da elasticidade-renda do dispêndio com legumes e verduras: 0,81 .

Foi mencionado no item (6.1) que não seria possível comparar o item legumes e verduras apresentado na POF com o respectivo item do ENDEF por agregarem produtos diferentes. Dessa forma, optou-se por comparar apenas três dos principais alimentos que compõe esse item: a alface, o tomate e a cebola. Vale ressaltar que esses três alimentos juntos correspondem a $50 \%$ do total das despesas com legumes e verduras da POF.

As Figuras 8, 9 e 10 apresentam os prę̧os médios anuais da alface, da cebola e do tomate, entre os anos de 1974 e 1988. A alface apresentou até o ano de 1982 preços médios próximos ao valor inicial de 1974. A partir de 1983, os preços se mantém acima do valor inicial, atingindo em 1986 o maior valor do período, cerca de 1,2 vezes maior do que em 1974. Em 1988 a alface custou 20\% mais caro do que em 1974. Mas, quando se consideram os períodos específicos nos quais as pesquisas ENDEF e POF foram realizadas, esse valor se eleva para $47 \%$.

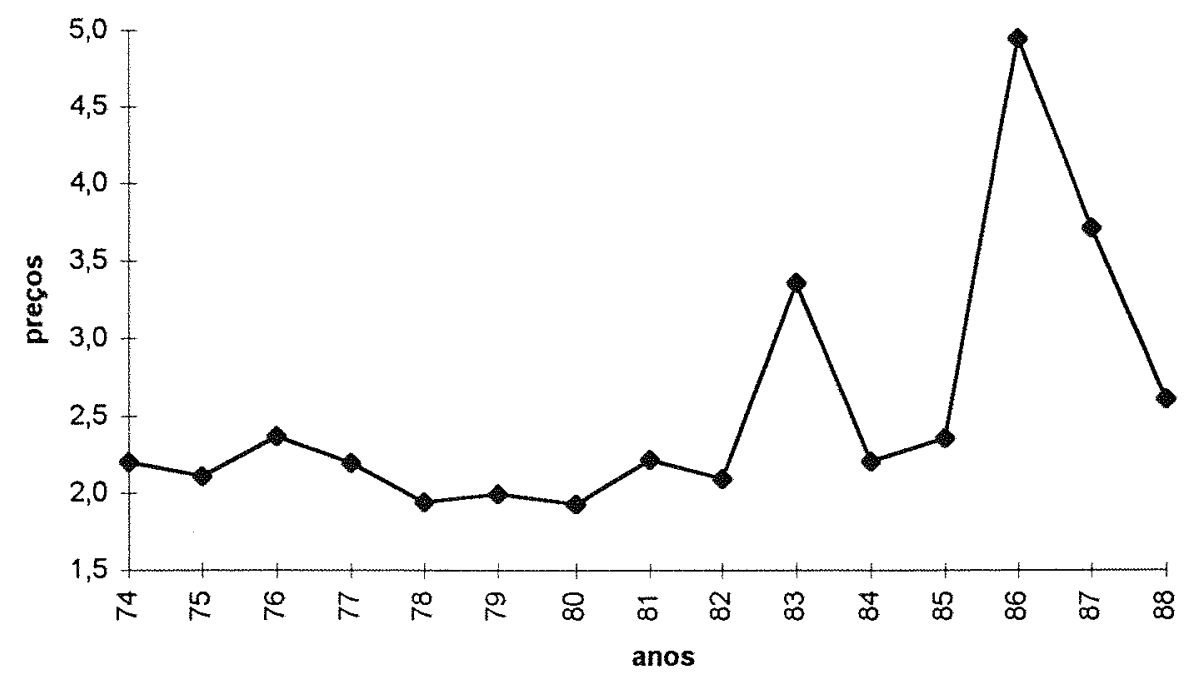

Figura 8 - Preços médios anuais do alface (pé) no varejo da cidade de São Paulo 1974/88. Em cruzados de março de 1986.

Fonte: Dados do IEA (1990) processados pelo autor. 
Com exceção do ano de 1981, os preços médios da cebola estiveram sempre acima daquele observado em 1974. A maior variação do período ocorreu em 1978, quando o preço médio foi 1,2 vezes maior do que o de 1974. Em 1981 a cebola atinge um valor $30 \%$ menor do que o inicial. A partir deste ano, os preços se recuperam, atingindo em 1988 um valor $46 \%$ maior do que o de 1974. Quando se consideram os períodos específicos nos quais as pesquisas ENDEF e POF foram realizadas, observa-se que, pelo contrário, houve uma redução no seu valor de $16 \%$.

Em 1975 e 1976 os preços médios do tomate de mesa mantiveram-se acima do valor de 1974. A partir de 1976 os preços caem, atingindo em 1982 uma valor cerca de 13\% menor do que o observado em 1974. Em 1986, o tomate alcança o preço mais elevado do período, $56 \%$ mais alto do que no ano base. A partir de 1987 os preços caem, atingindo em 1988 um valor 9\% menor do que em 1974. Quando se consideram os períodos específicos nos quais as pesquisas ENDEF e POF foram realizadas observa-se uma elevação nos preços de $9 \%$.

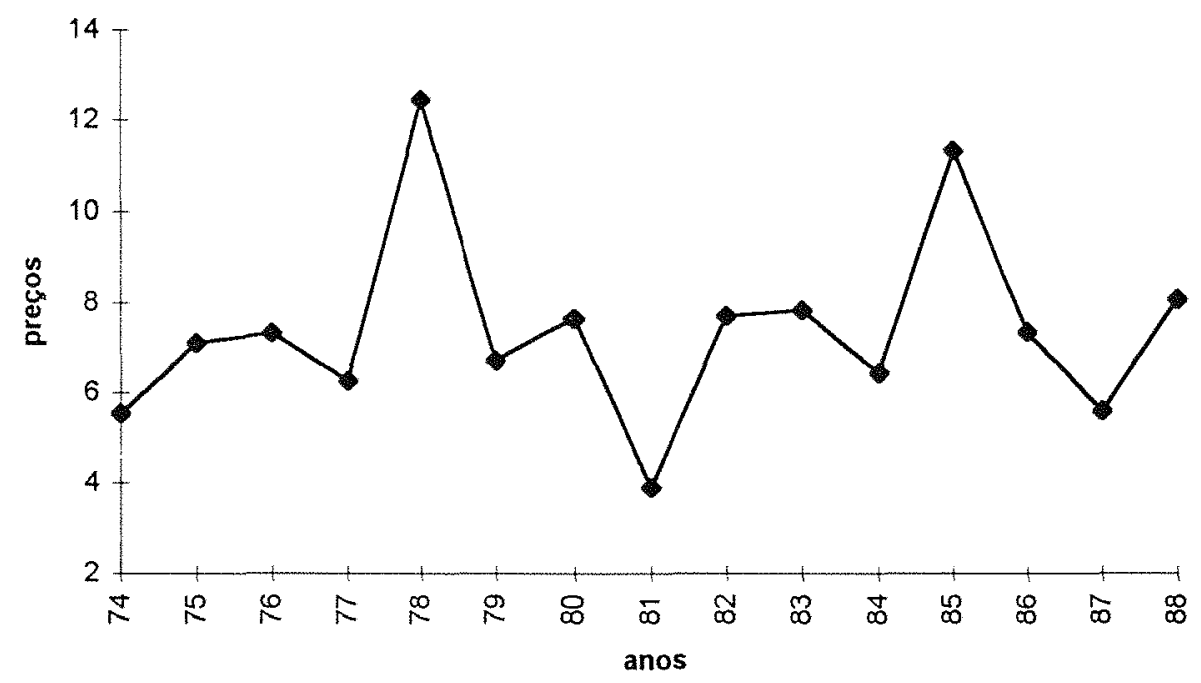

Figura 9 - Preços médios anuais da cebola (kg) no varejo da cidade de São Paulo 1974/88. Em cruzados de março de 1986.

Fonte: Dados do IEA (1990) processados pelo autor

Comparando os resultados das pesquisas ENDEF e POF (ver Tabela 16), observa-se que as quantidades consumidas de tomate e alface apresentaram uma redução de $20,88 \%$ e $25,42 \%$. A cebola, por sua vez, apresentou elevação no consumo de 
$52,82 \%$. Utilizando-se o valor médio desses 3 produtos obtém-se uma elevação de $1,25 \%$ no consumo desses vegetais. As despesas médias monetárias anuais com esses três ítens diminuíram 41,98\% entre 1974/75 e 1987/88 (ver Tabela 17).

De forma geral, os preços de tomate, cebola e alface apresentados acima não se mostraram favoráveis ao aumento no consumo desses produtos. Pelo contrário, as variações nos preços do tomate e da alface podem ter induzido uma redução em seu consumo.

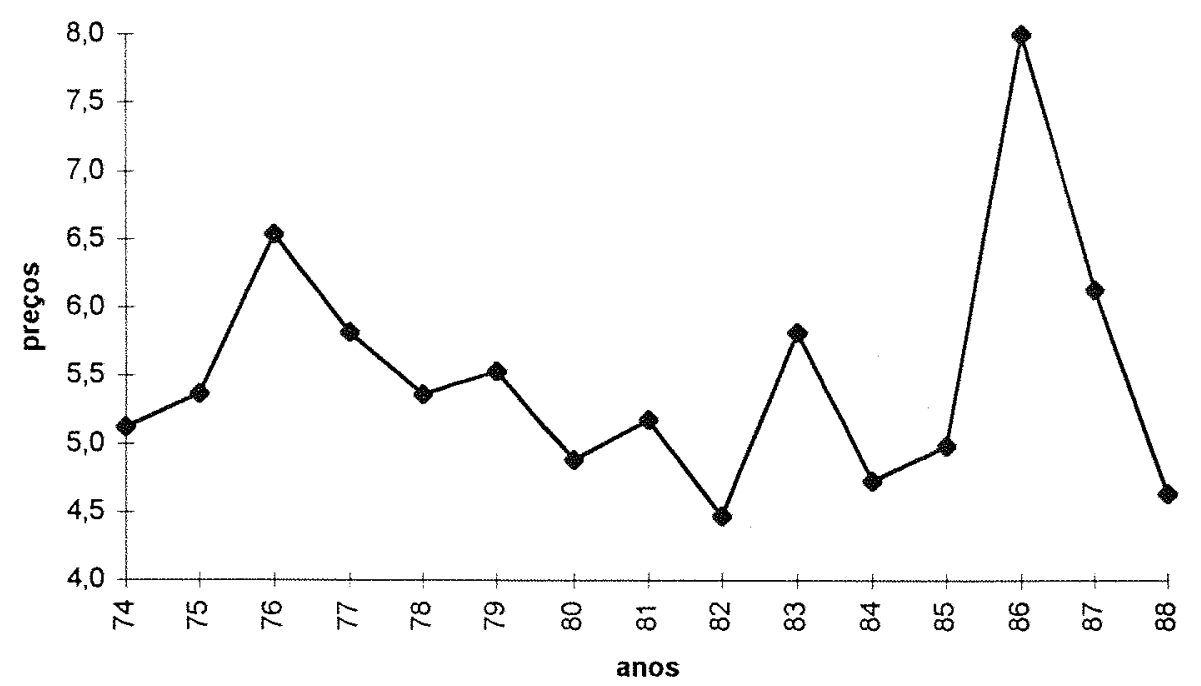

Figura 10 - Preços médios anuais do tomate de mesa (kg) no varejo da cidade de São Paulo - 1974/88. Em cruzados de março de 1986.

Fonte: Dados do IEA (1990) processados pelo autor.

Considerando o aumento de 32\% no PIB per capita entre 1974 e 1988 e admitindo que a distribuição da renda tenha se mantido inalterada, obtém-se, a partir da elasticidade média calculada para o item legumes e verduras $(0,298)$, um aumento nas despesas com esses produtos de 6,85\%. A diversidade de produtos envolvidos torna dificil, nesse caso, avaliar a direção e dimensão dos efeitos de possíveis mudanças nos hábitos alimentares. 


\subsubsection{Batata inglesa}

Os resultados do ajustamento de poligonais log-log aos dados de despesa com batata inglesa para onze áreas urbanas do Brasil encontram-se na Tabela 26. Em Porto Alegre e em Curitiba os valores de $F$ não são significativos ao nível de $10 \%$ e $5 \%$, respectivamente. Porém, nos demais locais os valores de $F$ mostram-se significativos ao nível de $5 \%$.

Não é possível encontrar um comportamento típico nos coeficientes de elasticidade-renda das despesas com batata inglesa. Em Goiânia, Brasilia, Curitiba, Belo Horizonte e Fortaleza os coeficientes apresentaram-se positivos e decrescentes com a elevação da renda. Nas localidades restantes a elasticidade-renda mostra-se crescente entre o primeiro e segundo estratos e decrescente entre o segundo e o terceiro. Nestes casos, observa-se que, com exceção de São Paulo, os coeficientes do primeiro estrato são maiores do que os encontrados no terceiro estrato.

Em Goiânia, São Paulo, Belo Horizonte, Salvador e Belém as variações são estatisticamente significativas, pelo teste $t$, entre ao menos dois dos três estratos considerados, a um nível de $10 \%$. Apenas em Porto Alegre, Curitiba, e Belém os coeficientes do primeiro estrato não diferem estatisticamente de zero.

Nas áreas urbanas estudadas, o coeficiente médio de elasticidade-renda apresenta-se, na maioria dos casos, positivo e com valor sempre superior a 0,200. Em Fortaleza, este coeficiente atinge o valor máximo de 0,662. Em seguida destacam-se Brasília, com 0,421 e Recife, com 0,416. A elasticidade média apresenta sinal negativo somente em Porto Alegre, onde seu valor está muito próximo de zero. Este resultado mostra que o nível de consumo atual já é alto e pode ser explicado pela predominância de descendentes de europeus na sua população.

A elasticidade média geral, ponderada para as onze áreas urbanas, é de 0,238. Melo (1988), utilizando dados do ENDEF referentes a 1974/75, obteve um valor cerca 
de duas vezes maior do que este para o coeficiente médio da elasticidade-renda do dispêndio com batata para o Brasil como um todo: 0,69.

TABELA 26 - Coeficientes de Elasticidade-renda da despesa per capita com batata inglesa nos estratos considerados para 11 áreas urbanas do Brasil, obtidos através do ajustamento de uma poligonal log-log de acordo com dados da POF (1987-88).

\begin{tabular}{|c|c|c|c|c|c|c|c|c|}
\hline \multirow[b]{2}{*}{ Área urbana } & \multirow{2}{*}{$\begin{array}{l}\text { Esquema de } \\
\text { agrupamento }\end{array}$} & \multirow[t]{2}{*}{$R^{2}$} & \multirow{2}{*}{$\begin{array}{l}C V \\
\%\end{array}$} & \multicolumn{3}{|c|}{ Elasticidade do estrato } & \multirow{2}{*}{$\begin{array}{c}\text { Elasticidade } \\
\text { médial }^{\mathrm{l}}\end{array}$} & \multirow{2}{*}{$\begin{array}{l}\text { Valor } \\
\text { de } F\end{array}$} \\
\hline & & & & I & II & III & & \\
\hline Goiânia & $1-8-1$ & 0,94 & 5,7 & $1,799^{* *}$ & $0,324^{\circ}$ & 0,158 & 0,315 & $29,88^{* *}$ \\
\hline Brasilia & $6-2-2$ & 0,96 & 5,7 & $0,504^{* *}$ & 0,475 & 0,344 & 0,421 & $51,61^{* *}$ \\
\hline Porto Alegre & $2-1-7$ & 0,14 & 5,4 & $-0,046$ & 0,246 & $-0,081$ & $-0,019$ & 0,32 \\
\hline Curitiba & $1-8-1$ & 0,67 & 6,7 & 0,677 & 0,217 & 0,039 & 0,201 & $3,98^{\circ}$ \\
\hline São Paulo & $3-3-4$ & 0,97 & 2,1 & $-0,213^{* *}$ & $0,617^{\cdots *}$ & $0,226^{*}$ & 0,256 & $62,94^{* *}$ \\
\hline Rio de Janeiro & $5-2-3$ & 0,96 & 2,1 & $0,159^{* *}$ & 0,392 & 0,146 & 0,206 & $45,56^{* *}$ \\
\hline Belo Horizonte & $2-7-1$ & 0,95 & 3,2 & $0,540^{* *}$ & 0,241 & $0,200^{\circ}$ & 0,263 & $37,98^{* *}$ \\
\hline Salvador & $5-4-1$ & 0,97 & 5,0 & $0,194^{* *}$ & $0,676^{* *}$ & $0,084^{*}$ & 0,365 & $70,35^{* *}$ \\
\hline Recife & $7-2-1$ & 0,96 & 7,1 & $0,412^{* *}$ & 0,678 & 0,229 & 0,416 & $42,97^{* *}$ \\
\hline Fortaleza & $6-1-3$ & 0,99 & 6,4 & $1,014^{* *}$ & 0,525 & 0,388 & 0,662 & $261,71^{* *}$ \\
\hline Belém & $6-3-1$ & 0,92 & 8,8 & 0,092 & $1,033^{* *}$ & $-0,224^{*}$ & 0,378 & $22,11^{* *}$ \\
\hline
\end{tabular}

Fonte: Dados da IBGE $(1991, \mathrm{n} .1)$ processados pelo autor.

${ }^{1}$ A elasticidade média geral ponderada para as 11 áreas urbanas é de 0,238.

No primeiro estrato o teste $t$ refere-se à hipótese de que a elasticidade-renda é igual a zero. No segundo e terceiro estratos, o teste $t$ refere-se à hipótese de que a diferença da elasticidade do estrato em relação à do estrato anterior é igual a zero.

" Significativo ao nível de $5 \%$.

* Significativo ao nivel de $10 \%$.

A Tabela 16 mostra que o consumo anual per capita de batata inglesa sofreu uma redução de 13,56\%, passando de $15,172 \mathrm{~kg}$ em 1974/75 para 13,114 kg em 
1987/88. De acordo com a Tabela 17 essa diminuição no consumo corresponde a uma redução de $41,87 \%$ nas despesas com esse produto.

De acordo com a elasticidade média geral calculada $(0,238)$, a elevação de 32\% no PIB per capita dos brasileiros, observada entre 1974 e 1988, deveria ter resultado numa elevação de $7,62 \%$ no consumo de batata inglesa, considerando que a distribuição da renda tenha se mantido inalterada. Com base nas quantidades físicas consumidas no período abordado pelo ENDEF $(15,172 \mathrm{~kg})$ o aumento da renda causaria um aumento no consumo de batata inglesa de $1,156 \mathrm{~kg}$. No entanto isso não foi observado, pelo contrário, houve uma redução no consumo de batata inglesa.

A Figura 11 apresenta o comportamento dos preços médios da batata inglesa no varejo da cidade de São Paulo entre os anos de 1974 e 1988. Os preços atingiram seu menor valor em 1982, tornando a batata 33\% mais barata do que em 1974. A maior variação positiva ocorreu em 1986, quando a batata custou $54 \%$ mais do que no ano base. Em 1988 a batata custou 18\% mais barato do que em 1974. Quando se comparam os periodos especificos nos quais as pesquisas ENDEF e POF foram realizadas observase uma elevação de $17 \%$ nos preços desse produto

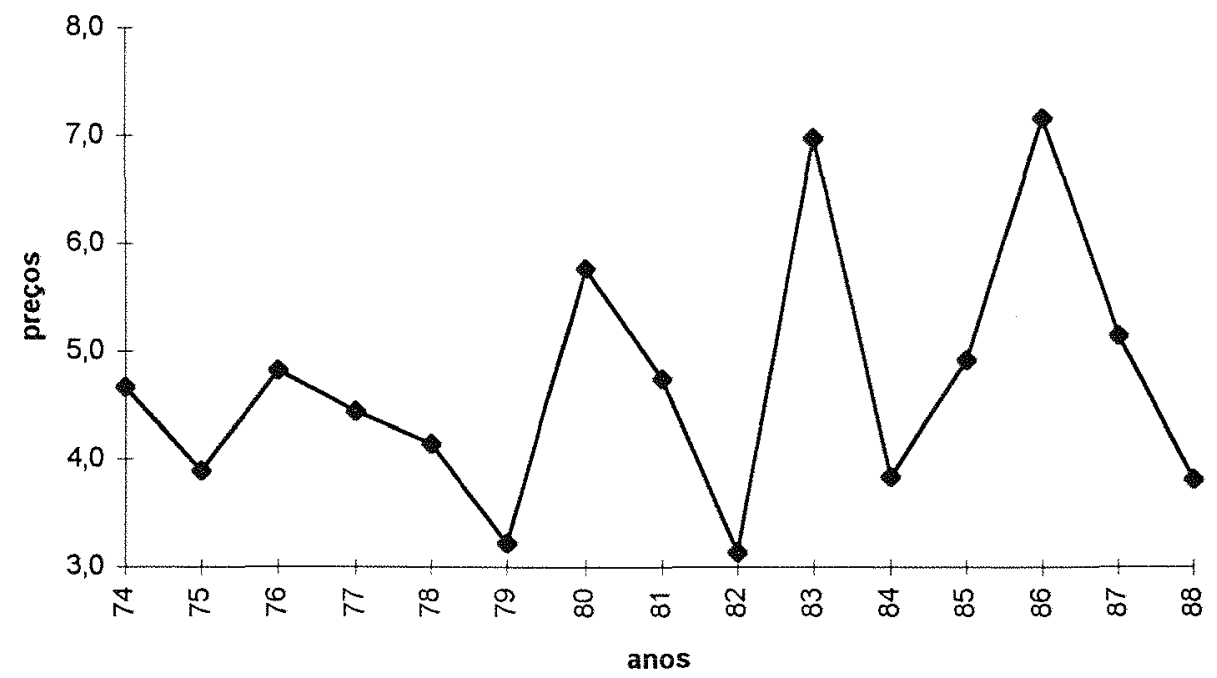

Figura 11 - Preços médios anuais da batata inglesa $(\mathrm{kg})$ no varejo da cidade de São Paulo - 1974/88. Em cruzados de março de 1986.

Fonte: Dados do IEA (1990) processados pelo autor. 
Como os preços da batata inglesa variaram bastante, os seus efeitos no consumo não são claros. Porém, pode-se afirmar que, em geral, os preços não favoreceram o consumo.

Conclui-se que a redução observada no consumo de batata inglesa ocorreu devido a mudanças nos hábitos alimentares, uma vez que a renda atuou de maneira favorável no aumento no consumo. Certamente o consumo de batata está sendo substituído por outros produtos. A Tabela 16 mostra que houve um aumento no consumo total de alimentos nesse período de $58,145 \mathrm{~kg}$, evidenciando que a redução no consumo de alguns alimentos, como no caso da batata inglesa, está sendo compensado pelo aumento no consumo de outros. No entanto, é dificil indicar com base nos dados analisados, quais alimentos estão substituindo a batata inglesa.

\subsubsection{Leite pasteurizado}

A Tabela 27 mostra os resultados do ajuste da poligonal log-log aos dados sobre dispêndio com leite pasteurizado de onze áreas urbanas do Brasil. Valores de $F$ significativos ao nível de $5 \%$ são freqüentes. Somente em Belém o valor de $F$ é não significativo.

No que diz respeito à qualidade dos ajustamentos, o coeficiente de variação $(C V)$ e o coeficiente de determinação $\left(R^{2}\right)$ mostram resultados semelhantes. Em Belém, onde o coeficiente de determinação $\left(R^{2}\right)$ atinge o seu menor valor, 0,52 , observa-se também o maior valor do coeficiente de variação, 28,7\%. Nas demais áreas urbanas, onde são observados valores elevados no coeficiente de determinação $\left(R^{2}\right)$, os valores do coeficiente de variação $(C V)$ são sempre inferiores a $5 \%$.

As estimativas da elasticidade-renda da despesa com leite pasteurizado não se apresentam decrescentes com a elevação da renda. Assim como ocorre com óleos e gorduras (item 6.2.3) e legumes e verduras (item 6.2.8), os coeficientes de elasticidade mostram-se crescentes entre o primeiro e segundo estratos e decrescentes entre o segundo e terceiro estratos. Para a maioria dos casos o coeficiente do primeiro estrato 
apresenta valor maior do que o coeficiente do terceiro estrato. Apenas em Belém não se observou tal comportamento.

TABELA 27 - Coeficientes de Elasticidade-renda da despesa per capita com leite pasteurizado nos estratos considerados para 11 áreas urbanas do Brasil, obtidos através do ajustamento de uma poligonal log-log de acordo com dados da POF (1987-88).

\begin{tabular}{lccccccccc}
\hline & Esquema de & $R^{2}$ & $C V$ & \multicolumn{2}{c}{ Elasticidade do estrato } & Elasticidade & Valor \\
Área urbana & agrupamento & & $\%$ & I & II & III & média ${ }^{1}$ & de $F$ \\
\hline Goiânia & $6-1-3$ & 0,90 & 2,7 & $0,231^{*}$ & 0,749 & 0,108 & 0,254 & $18,32^{* *}$ \\
Brasilia & $7-1-2$ & 0,90 & 3,1 & $0,226^{* *}$ & 0,821 & 0,148 & 0,269 & $17,10^{* *}$ \\
Porto Alegre & $3-6-1$ & 0,83 & 2,6 & 0,073 & 0,327 & 0,016 & 0,230 & $9,76^{* *}$ \\
Curitiba & $2-7-1$ & 0,91 & 2,1 & 0,068 & 0,338 & $-0,043$ & 0,254 & $20,21^{* *}$ \\
São Paulo & $6-1-3$ & 0,97 & 1,0 & $0,138^{* *}$ & $0,721^{* *}$ & $0,085^{* *}$ & 0,221 & $58,03^{* *}$ \\
Rio de Janeiro & $7-2-1$ & 0,94 & 1,7 & $0,156^{* *}$ & $0,691^{*}$ & 0,063 & 0,248 & $32,87^{* *}$ \\
Belo Horizonte & $4-4-2$ & 0,99 & 1,4 & $0,248^{* *}$ & $0,702^{* *}$ & $0,189^{* *}$ & 0,436 & $156,56^{* *}$ \\
Salvador & $3-5-2$ & 0,94 & 3,4 & $-0,098$ & $0,750^{* *}$ & $-0,132^{* *}$ & 0,311 & $29,84^{* *}$ \\
Recife & $3-6-1$ & 0,99 & 3,8 & $0,434^{* *}$ & $0,927^{* *}$ & $0,211^{*}$ & 0,619 & $135,03 *$ \\
Fortaleza & $2-6-2$ & 0,99 & 2,1 & $0,618^{* *}$ & 0,685 & $0,161^{* *}$ & 0,525 & $199,36^{* *}$ \\
Belém & $3-1-6$ & 0,52 & 28,7 & $-0,253$ & 4,259 & 0,299 & 0,507 & 2,20 \\
\hline
\end{tabular}

Fonte: Dados da IBGE $(1991, \mathbf{n} .1)$ processados pelo autor.

1 A elasticidade média geral ponderada para as 11 áreas urbanas é de 0,259.

No primeiro estrato o teste $t$ refere-se à hipótese de que a elasticidade-renda é igual a zero. No segundo e terceiro estratos, o teste $t$ refere-se à hipótese de que a diferença da elasticidade do estrato em relação à do estrato anterior é igual a zero.

${ }^{* *}$ Significativo ao nível de $5 \%$.

* Significativo ao nivel de $10 \%$.

Nos 3 estratos predominaram sinais positivos nos coeficientes de elasticidade. Belém apresenta sinal negativo no coeficiente do primeiro estrato, o mesmo ocorrendo 
em Salvador, que também exibe sinal negativo no coeficiente do terceiro estrato. Curitiba apresenta sinal negativo apenas no terceiro estrato.

Em São Paulo, Rio de Janeiro, Belo Horizonte, Salvador, Recife e Fortaleza as variações entre ao menos dois dos estratos considerados são estatisticamente significativas ao nível de 5\% na maior parte dos casos. Nas demais áreas as variações entre os estratos não são significativas. Somente em Porto Alegre, Curitiba, Salvador e Belém os coeficientes do primeiro estrato não diferem estatisticamente de zero.

O leite pasteurizado apresenta elasticidade média variando entre 0,200 e 0,400 nas seguintes áreas urbanas: Goiânia, Brasilia, Porto Alegre, Curitiba, São Paulo, Rio de Janeiro e Salvador. Os maiores valores se situam entre 0,400 e 0,700 e podem ser observados nas seguintes localidades: Belo Horizonte, Recife, Fortaleza e Belém. O coeficiente de elasticidade média geral para as onze áreas urbanas é 0,259.

A Figura 12 apresenta o comportamento dos preços médios dos leites tipo B e C no varejo da cidade de São Paulo entre os anos de 1974 e 1988. Os preços do leite tipo $\mathrm{B}$ apresentam uma tendência baixista em quase todo o período de análise. Somente em 1975, 1977 e 1987 seus valores são superiores aos de 1974. Em 1988 o leite tipo B custou $4 \%$ menos do que em 1974. Considerando os períodos específicos nos quais as pesquisas ENDEF e POF foram realizadas, observa-se uma redução de 7\%.

Os preços médios do leite tipo $\mathrm{C}$ apresentaram os valores mais elevados do período em 1976, 59\% maiores do que os de 1974. Entre 1977 e 1979, os preços decaíram, mas em 1980 tornam a se elevar. A partir de 1982, os preços ficam muito próximos do valor do ano base e somente em 1986 há nova queda nos preços. Em 1988 o leite tipo C custou $8 \%$ mais caro do que em 1974 e quando se consideram os períodos especificos nos quais as pesquisas ENDEF e POF foram realizadas observa-se uma elevação de $10 \%$ nos preços.

A Tabela 16 mostra que no período que separa as pesquisas ENDEF (1974/75) e POF (1987/88) há uma elevação no consumo anual per capita de leite pasteurizado de 
$45,26 \%$, ou o equivalente a 19,402 litros. A Tabela 17 revela que essa elevação no consumo correspondeu a um aumento de $64,94 \%$ nas despesas com leite pasteurizado.

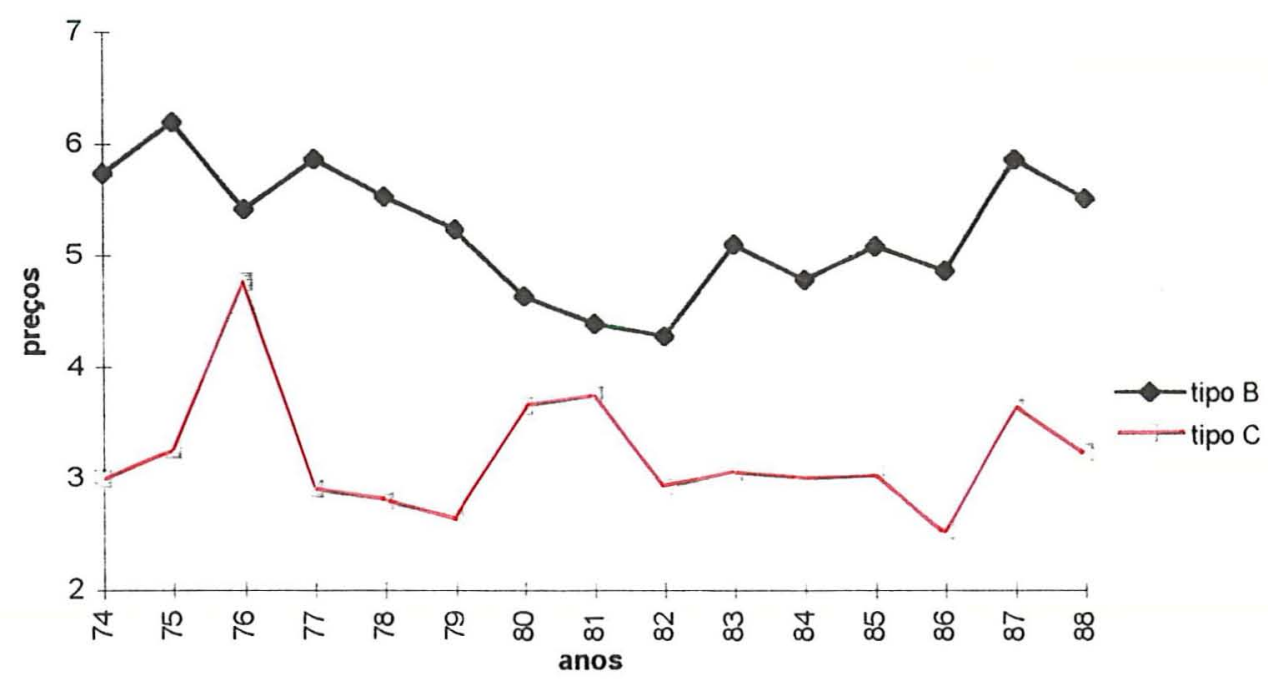

Figura 12 - Preços médios anuais do leite tipo B e tipo C (l) no varejo da cidade de São Paulo - 1974/88. Em cruzados de março de 1986.

Fonte: Dados do IEA (1990) processados pelo autor.

Vale ressaltar que as despesas mencionadas acima incluem o leite fresco e o pasteurizado no caso do ENDEF e incluem somente o valor das despesas com leite pasteurizado no caso da POF. No entanto, nas quantidades físicas consumidas está contabilizado, no ENDEF e na POF, apenas o leite pasteurizado. Tanto no ENDEF como na POF não há especificação quanto ao tipo de leite pasteurizado, se C, B ou A.

O coeficiente de elasticidade média geral de 0,259 indica que a elevação de $32 \%$ na renda per capita dos brasileiros ocorrida entre 1974 e 1988 tenderia a causar um aumento nas despesas com leite pasteurizado de $8,29 \%$. Tomando-se o consumo fisico de leite pasteurizado por comensal apresentado no ENDEF (42,870 1), obtém-se uma elevação de 3,55 1 no consumo de leite como consequeência do aumento da renda.

Já que os preços não tiveram efeito positivo no aumento do consumo de leite $\mathrm{e}$ a elevação da renda é capaz de explicar apenas pequena parte do aumento verificado, conclui-se que a mudança nos hábitos alimentares é o principal fator a se considerar nesse processo. 
Os principais atrativos do leite são a versatilidade, facilidade de preparo e a superioridade em termos nutricionais. Certamente foram estas as características que favoreceram o aumento em seu consumo. Como o leite pode ser consumido de inúmeras formas, ele é capaz de satisfazer os mais diversos paladares. Por ser um produto pronto para o consumo, o leite pasteurizado apresenta vantagens no que diz respeito ao tempo de preparo sobre aqueles alimentos utilizados tradicionalmente nas refeições como o arroz, feijão, carnes etc.

Como o custo de oportunidade dos indivíduos, principalmente das mulheres, tem se elevado, e também é crescente a demanda de tempo para lazer, o consumo de leite tem se tornado cada vez mais comum nas refeições.

É possivel que o crescimento do consumo de leite pasteurizado entre o ENDEF (1974/75) e a POF (1987/88) esteja refletindo, em parte, o incentivo ao seu consumo pelo Programa Nacional do Leite para Crianças Carentes, vigente entre 1985 e 1990. É dificil, entretanto, avaliar em quanto o consumo decorrente desse programa afeta os dados sobre consumo de leite da POF.

\subsubsection{Leite e derivados}

$\mathrm{Na}$ Tabela 28 encontram-se os resultados do ajustamento da poligonal log-log aos dados de despesa com leite e derivados das onze áreas urbanas do Brasil. Conforme pode ser observado, todos os valores de $F$ mostram-se bastante elevados, sendo significativos ao nível de $1 \%$. Como conseqüência, os valores do coeficiente de

determinação $\left(R^{2}\right)$ apresentam-se sempre muito próximos de 1 , indicando que houve um bom ajustamento da regressão aos dados. O menor valor do coeficiente de determinação $\left(R^{2}\right)$ foi observado em Porto Alegre: 0,92 .

Os valores do coeficiente de variação $(C V)$ também indicam que a regressão foi satisfatória. Valores muito próximos de $1 \%$ são freqüentes e o maior valor observado é inferior a $4 \%$. 
TABELA 28 - Coeficientes de Elasticidade-renda da despesa per capita com leite e derivados nos estratos considerados para 11 áreas urbanas do Brasil, obtidos através do ajustamento de uma poligonal log-log de acordo com dados da POF (198788).

\begin{tabular}{|c|c|c|c|c|c|c|c|c|}
\hline \multirow[b]{2}{*}{ Área urbana } & \multirow{2}{*}{$\begin{array}{l}\text { Esquema de } \\
\text { agrupamento }\end{array}$} & \multirow[t]{2}{*}{$R^{2}$} & \multirow{2}{*}{$\begin{array}{l}C V \\
\%\end{array}$} & \multicolumn{3}{|c|}{ Elasticidade do estrato } & \multirow{2}{*}{$\begin{array}{c}\text { Elasticidade } \\
\text { média }^{1}\end{array}$} & \multirow{2}{*}{$\begin{array}{l}\text { Valor } \\
\text { de } F\end{array}$} \\
\hline & & & & I & II & III & & \\
\hline Goiânia & $6-1-3$ & 0,96 & 1,5 & $0,142^{*}$ & 0,649 & 0,261 & 0,265 & $48,32^{* *}$ \\
\hline Brasilia & $7-2-1$ & 0,97 & 1,7 & $0,242^{* *}$ & $0,875^{* *}$ & $0,096^{*}$ & 0,337 & $71,58^{* *}$ \\
\hline Porto Alegre & $7-1-2$ & 0,92 & 1,9 & $0,240^{* *}$ & 0,847 & 0,236 & 0,287 & $22,96^{* *}$ \\
\hline Curitiba & $3-6-1$ & 0,93 & 2,2 & 0,141 & 0,497 & $-0,056^{*}$ & 0,333 & $26,04^{* *}$ \\
\hline São Paulo & $5-2-3$ & 0,99 & 0,6 & $0,202^{* *}$ & $0,430^{* *}$ & 0,298 & 0,305 & $203,41^{* *}$ \\
\hline Rio de Janeiro & $7-2-1$ & 0,98 & 1,7 & $0,329^{* *}$ & $0,950^{\circ}$ & 0,217 & 0,443 & $79,95^{* *}$ \\
\hline Belo Horizonte & $7-2-1$ & 0,98 & 1,6 & $0,348^{* *}$ & 0,831 & 0,310 & 0,441 & $89,14^{* *}$ \\
\hline Salvador & $4-5-1$ & 0,96 & 2,4 & $0,338^{* *}$ & 0,504 & 0,283 & 0,410 & $43,22^{* *}$ \\
\hline Recife & $4-3-3$ & 0,99 & 1,4 & $0,443^{* *}$ & $0,707^{*}$ & 0,430 & 0,516 & $222,73^{* *}$ \\
\hline Fortaleza & $4-4-2$ & 1,00 & 0,9 & $0,371^{* *}$ & $0,670^{* *}$ & $0,338^{* *}$ & 0,472 & $467,80^{* *}$ \\
\hline Belém & $6-3-1$ & 0,93 & 3,4 & 0,270 & 0,718 & 0,213 & 0,410 & $25,75^{* *}$ \\
\hline
\end{tabular}

Fonte: Dados da IBGE (1991, n.1) processados pelo autor.

1 A elasticidade média geral ponderada para as 11 áreas urbanas é de 0,366.

No primeiro estrato o teste $t$ refere-se à hipótese de que a elasticidade-renda é igual a zero. No segundo e terceiro estratos, o teste $t$ refere-se à hipótese de que a diferença da elasticidade do estrato em relação à do estrato anterior é igual a zero.

${ }^{* *}$ Significativo ao nível de $5 \%$.

* Significativo ao nível de $10 \%$.

Os coeficientes de elasticidade-renda da despesa com leite e derivados apresentam-se crescentes entre o primeiro e segundo estratos e decrescentes entre o segundo e terceiro estratos. De modo geral, os coeficientes do primeiro estrato mostram valores maiores do que os do terceiro estrato; somente em Goiânia e São Paulo isto não 
ocorreu. Com exceção de Curitiba, todos os coeficientes apresentam-se positivos nos 3 estratos.

Na maior parte das áreas urbanas estudadas, o terceiro estrato é composto por apenas uma classe de renda. Nos demais casos, o terceiro estrato é formado por, no máximo, três classes de renda, como é o caso de Goiânia, São Paulo e Recife.

Em Brasilia, Curitiba, São Paulo, Rio de Janeiro, Recife e Fortaleza, as variações são, pelo teste $t$, estatisticamente significativas entre ao menos dois dos estratos considerados, ao nível de $10 \%$. Nas demais áreas, as variações entre os estratos não são estatisticamente significativas. A maior parte das áreas urbanas estudadas apresenta coeficientes do primeiro estrato estatisticamente diferentes de zero, quase sempre ao nível de $5 \%$.

Utilizando dados referentes ao ano de 1971 para o município de Piracicaba, Perez (1973) obteve coeficientes de elasticidade-renda do dispêndio com leite e derivados decrescentes com a elevação da renda. Os coeficientes apresentaram os valores 1,62, 1,09 e 0,33 para o primeiro, segundo e terceiro estratos, respectivamente.

A elasticidade média apresenta coeficientes que variam entre 0,200 e 0,600 . Os menores valores são 0,265 e 0,287, observados em Goiânia e Porto Alegre, respectivamente. Recife apresenta o maior coeficiente, 0,516, seguido de Fortaleza, 0,472 , e do Rio de Janeiro, 0,443. A elasticidade média geral para as onze áreas urbanas é 0,366 .

Hoffmann \& Scampini (1996), utilizando dados provenientes da POF, estimaram que o coeficiente médio de elasticidade-renda do dispêndio com leite e derivados para as nove principais regiões metropolitanas do Brasil é aproximadamente 0,5. Melo (1988), utilizando dados do ENDEF referentes a 1974/75, para o Brasil como um todo, obteve um valor substancialmente maior para o valor do coeficiente médio da elasticidade-renda do dispêndio com leite e derivados: 1,10 . 
Nas Figuras 13, 14 e 15 são apresentados os preços médios do leite em pó, do queijo tipo minas e do queijo prato no varejo da cidade de São Paulo nos anos de 1974 a 1988.

Os preços médios do leite em pó mantiveram-se, quase sempre, acima do valor inicial (1974). Em 1976 e 1979 os preços médios do leite em pó apresentaram os valores mais baixos do período, cerca de 5\% menos do que em 1974. Nos anos de 1981, 1983 e 1987 os preços médios deste produto se elevaram em cerca de $20 \%$ sobre o valor de 1974. Comparando os preços do leite em pó de 1988 com os de 1974 obtém-se uma redução de menos de 1\%. Quando se comparam os períodos específicos nos quais as pesquisas ENDEF e POF foram realizadas, observa-se uma elevação de $13 \%$ nos preços deste produto.

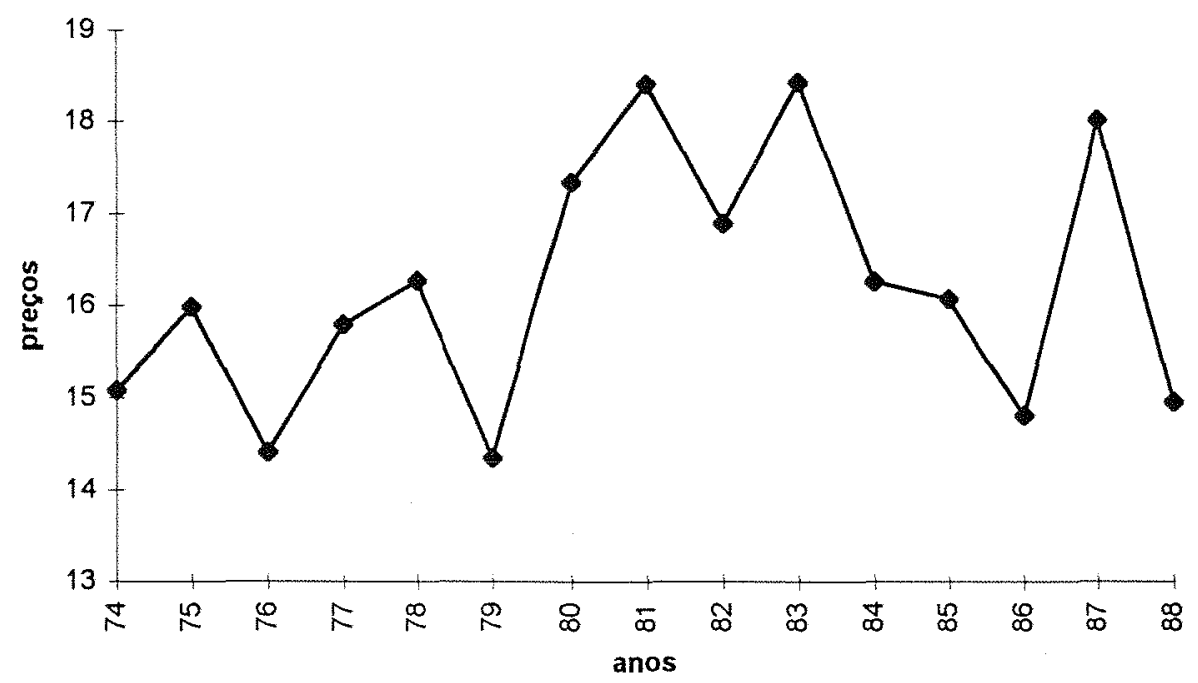

Figura 13 - Preços médios anuais do leite em pó (kg) no varejo da cidade de São Paulo - 1974/88. Em cruzados de março de 1986.

Fonte: Dados do IEA (1990) processados pelo autor.

De acordo com a Figura 14, pode-se notar que os preços médios do queijotipo minas mantiveram-se, em todo o periodo analisado, relativamente próximos do valor inicial de 1974. O ano de 1976 foi aquele em que o queijo minas custou mais barato, cerca de $11 \%$ menos do que no ano base. A maior variação positiva ocorreu em 1980 , quando custou $16 \%$ mais caro do que em 1974. Em 1988 esse preço era $12 \%$ maior do que em 1974. 


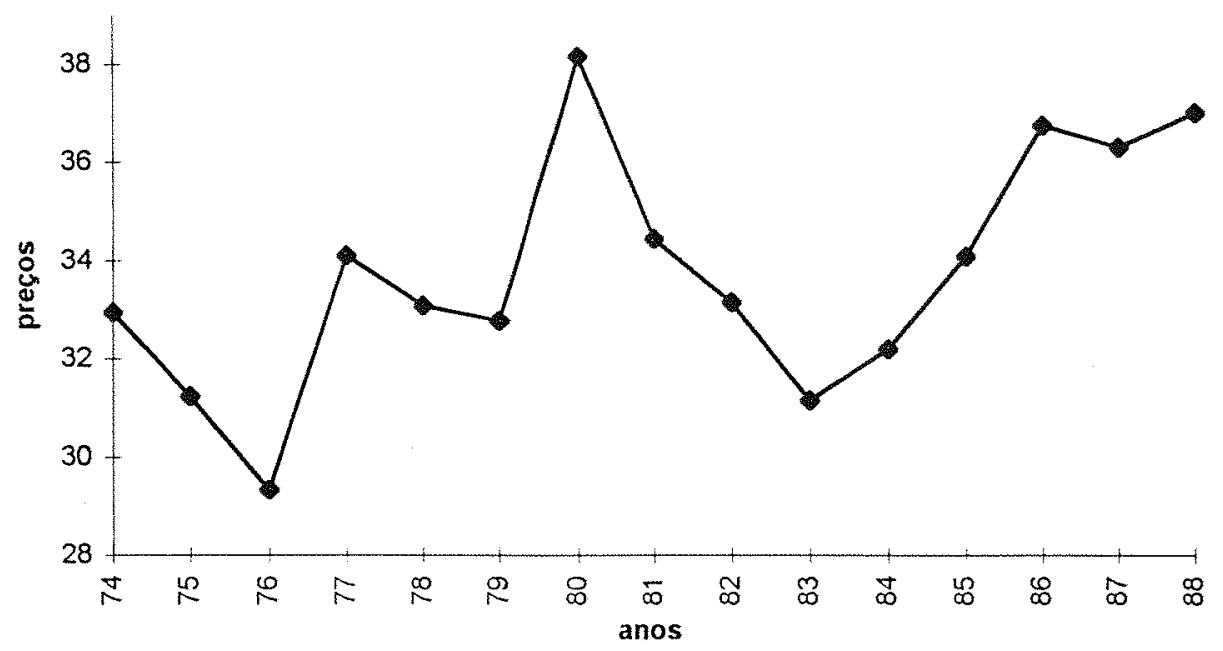

Figura 14 - Preços médios anuais do queijo-tipo minas (kg) no varejo da cidade de São Paulo - 1974/88. Em cruzados de março de 1986.

Fonte: Dados do IEA (1990) processados pelo autor.

A Figura 15 mostra que apenas em 1975 e 1976 os preços médios do queijotipo prato ficaram abaixo do valor inicial de 1974. A partir de 1977 seus preços mantiveram-se elevados, atingindo um máximo em 1980, 29\% acima do valor de 1974. Em 1988 o queijo prato custou 16\% mais caro do que em 1974.

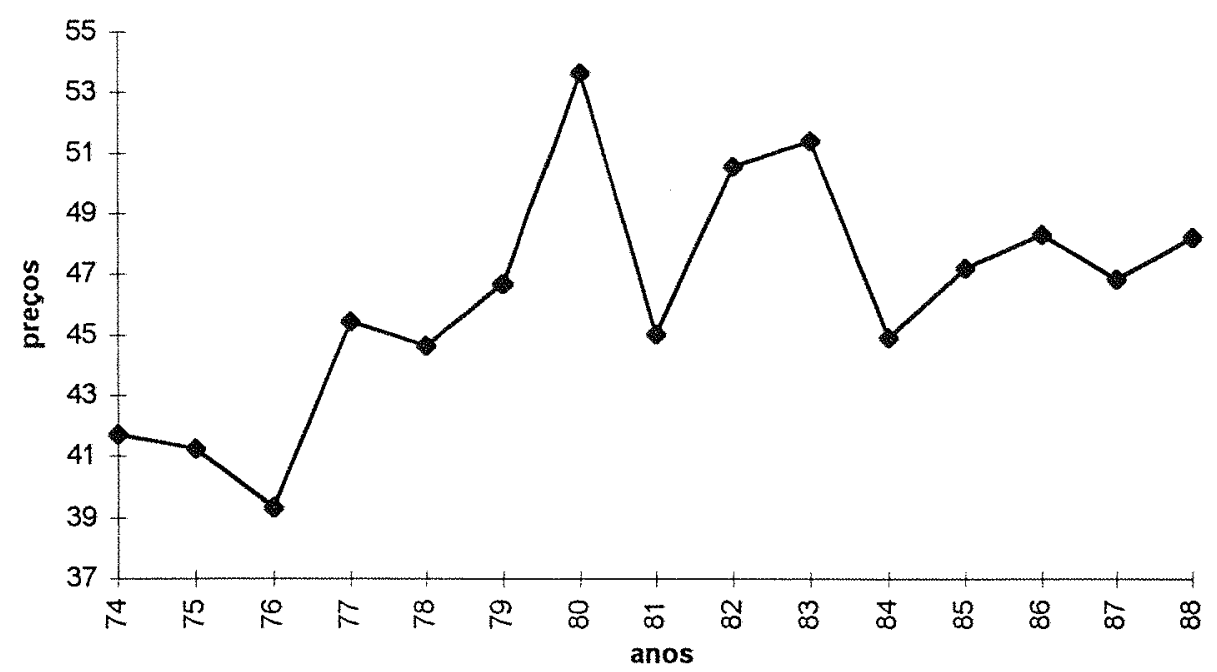

Figura 15 - Preços médios anuais do queijo-tipo prato $(\mathrm{kg})$ no varejo da cidade de São Paulo - 1974/88. Em cruzados de março de 1986.

Fonte: Dados do IEA (1990) processados pelo autor. 
No periodo que separa as pesquisas ENDEF (1974/75) e POF (1987/88), notase, na Tabela 16, que houve uma elevação no consumo per capita de leite e derivados de $40,12 \%$, ou o equivalente a $20,149 \mathrm{~kg}$. Isso correspondeu, de acordo com a Tabela 17 , a um aumento de $42,27 \%$ nas despesas médias monetárias anuais com esse grupo de produtos.

O coeficiente de elasticidade média geral mostra que, mantendo-se inalterada a distribuição da renda, a elevação de 32\% no PIB per capita observado entre 1974 e 1988 levaria a uma elevação de $11,71 \%$ nas despesas dos residentes nas áreas urbanas do Brasil com esses produtos. Este valor é maior do que o obtido para o leite pasteurizado.

Conforme o que foi apresentado nas Figuras 12, 13, 14 e 15, os preços médios dos principais produtos que compõe o grupo do leite e derivados não tiveram um comportamento que favorecesse o aumento em seu consumo.

Como os preços do grupo do leite e derivados não foram favoráveis ao aumento no consumo e o efeito da renda explica apenas uma pequena parte desse aumento, conclui-se que a mudança nos hábitos alimentares teve grande importância nesse processo. Uma característica marcante desse grupo de alimentos é que não exigem um grande tempo de preparo para serem consumidos e incluem uma grande diversidade de produtos, o que os tem tornado, cada vez mais, atrativos para uma grande parcela da população.

\subsubsection{Ovos}

A Tabela 29 apresenta os resultados do ajustamento de poligonais log-log aos dados de despesa com ovos para onze áreas urbanas do Brasil. Na maioria das localidades, os valores de $F$ mostram-se significativos ao nivel de $5 \%$. Em Curitiba, o valor de $F$ é significativo apenas ao nível de $10 \%$. Em Porto Alegre e Salvador os valores de $F$ são muito baixos e não são significativos. 
TABELA 29 - Coeficientes de Elasticidade-renda da despesa per capita com ovos nos estratos considerados para 11 áreas urbanas do Brasil, obtidos através do ajustamento de uma poligonal log-log de acordo com dados da POF (198788).

\begin{tabular}{lccccccccc}
\hline & Esquema de & $R^{2}$ & $C V$ & \multicolumn{2}{c}{ Elasticidade do estrato } & Elasticidade & Valor \\
Área urbana & agnipamento & & $\%$ & I & II & III & média & de $F$ \\
\hline Goiânia & $3-2-5$ & 0,73 & 4,4 & 0,200 & 0,193 & 0,129 & 0,154 & $5,50^{* *}$ \\
Brasilia & $7-2-1$ & 0,83 & 4,9 & 0,075 & $0,931^{*}$ & $-0,284^{*}$ & 0,179 & $9,61^{* *}$ \\
Porto Alegre & $1-8-1$ & 0,55 & 4,3 & 0,765 & 0,103 & $-0,219$ & 0,097 & 2,48 \\
Curitiba & $1-8-1$ & 0,68 & 4,1 & 0,676 & 0,181 & $-0,382^{*}$ & 0,127 & $4,28^{* *}$ \\
São Paulo & $7-2-1$ & 0,74 & 2,5 & 0,029 & $0,622^{*}$ & $-0,374^{* *}$ & 0,118 & $5,67^{* *}$ \\
Rio de Janeiro & $8-1-1$ & 0,88 & 3,9 & $0,224^{* *}$ & 0,847 & $-0,009$ & 0,251 & $14,58^{* *}$ \\
Belo Horizonte & $4-5-1$ & 0,88 & 4,3 & 0,023 & $0,459^{*}$ & 0,016 & 0,255 & $14,81^{* *}$ \\
Salvador & $3-1-6$ & 0,37 & 5,6 & 0,075 & 0,337 & 0,073 & 0,088 & 1,19 \\
Recife & $6-3-1$ & 0,80 & 5,4 & $0,263^{* *}$ & 0,215 & 0,207 & 0,243 & $8,21^{* *}$ \\
Fortaleza & $2-7-1$ & 0,95 & 2,5 & $0,494^{*}$ & 0,235 & $-0,115$ & 0,242 & $37,32^{* *}$ \\
Belém & $8-1-1$ & 0,75 & 3,4 & 0,078 & $1,279^{*}$ & $-0,617^{*}$ & 0,133 & $6,00^{* *}$ \\
\hline
\end{tabular}

Fonte: Dados da IBGE (1991, n.1) processados pelo autor.

1 A elasticidade média geral ponderada para as 11 áreas urbanas é de 0,170.

No primeiro estrato o teste $t$ refere-se à hipótese de que a elasticidade-renda é igual a zero. No segundo e terceiro estratos, o teste $t$ refere-se à hipótese de que a diferença da elasticidade do estrato em relação à do estrato anterior é igual a zero.

** Significativo ao nível de 5\%.

* Significativo ao nível de $10 \%$.

Não é possível encontrar um comportamento padrão para os coeficientes de elasticidade-renda da despesa com ovos. Em Goiânia, Porto Alegre, Curitiba, Recife e Fortaleza, os coeficientes apresentam-se decrescentes com a elevação da renda. Nas demais áreas urbanas, a elasticidade-renda mostra-se crescente entre o primeiro e segundo estrato e decrescente entre o segundo e o terceiro. E, nestes casos, observa-se 
que os coeficientes do primeiro estrato são maiores do que os encontrados no terceiro estrato.

No primeiro e segundo estratos, todos os coeficientes tem sinais positivos. O mesmo não ocorre no terceiro estrato, onde a maioria dos coeficientes são negativos.

Em Brasília, Curitiba, São Paulo, Belo Horizonte e Belém, as variações entre ao menos dois dos estratos considerados, são estatisticamente significativas pelo teste $t$, na maioria dos casos a um nivel de 10\%. Nas demais áreas, as variações entre os estratos não são estatisticamente significativas.

Os coeficientes de elasticidade-renda da despesa com ovos para o municipio de Piracicaba, calculados por Perez (1973), se mostraram crescentes entre o primeiro e segundo estratos e decrescentes entre o segundo e terceiro estratos. Os valores dos coeficientes de elasticidade para o primeiro, segundo e terceiro estratos foram $0,88,1,71$ e 0,13 , respectivamente

Os coeficientes da elasticidade-renda média apresentam-se positivos em todas as áreas urbanas estudadas. Os maiores valores são observados em Belo Horizonte, 0,255, e no Rio de Janeiro, 0,251. Os menores valores encontram-se em Porto Alegre e Salvador, 0,097 e 0,088, respectivamente. O coeficiente de elasticidade média geral para as onze áreas urbanas é 0,170 .

Este valor é inferior ao valor obtido para os anos de $1974 / 75$, calculado por Melo (1988) para o Brasil como um todo. Utilizando dados fornecidos pelo ENDEF, este autor obteve o valor 0,51 para o coeficiente médio da elasticidade-renda do dispêndio com ovos.

Entre os anos de 1974 e 1988 houve uma elevação de 13,35\% no consumo médio anual per capita de ovos dos brasileiros residentes nas áreas urbanas abrangidas pela ENDEF e pela POF, que equivale à cerca de 1 dúzia de ovos (Tabela 16). Em 
termos de despesas médias monetárias anuais per capita, houve nesse período, uma redução de $22,73 \%$ (Tabela 17 ).

Considerando o coeficiente de elasticidade média geral desse produto $(0,170)$, a elevação de $32 \%$ na renda per capita observada entre 1974 e 1988 teria promovido um aumento de $5,44 \%$ nas despesas com ovos. Tomando-se a quantidade física por comensal desse produto apresentada no ENDEF ( $7,977 \mathrm{dz})$, obtém-se, considerando o aumento nas despesas, uma elevação de menos de meia dúzia (cerca de 5 unidades) no consumo de ovos.

$\mathrm{Na}$ Figura 16 estão representadas as variações nos preços médios do ovo entre os anos de 1974 e 1988 no varejo da cidade de São Paulo. Com exceção do ano de 1984, observa-se que em todo o periodo de análise os preços estiveram mais baixos do que em 1974. Em 1988, a dúzia de ovos custou 14\% mais barato do que em 1974. Quando comparamos os períodos específicos nos quais as pesquisas ENDEF e POF foram realizadas, observa-se uma redução de $15 \%$ nos preços.

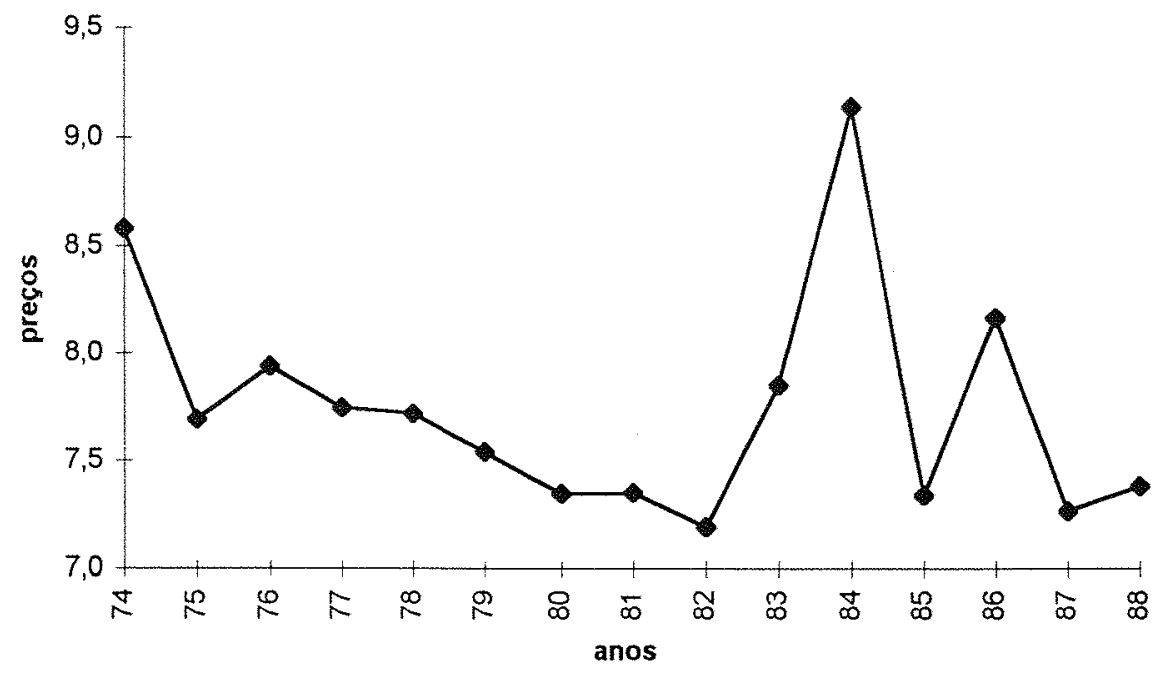

Figura 16 - Preços médios anuais do ovo (kg) no varejo da cidade de São Paulo 1974/88. Em cruzados de março de 1986.

Fonte: Dados do IEA (1990) processados pelo autor.

É certo que a elevação na renda responde por boa parte do aumento observado no consumo de ovos e os preços observados no período também contribuíram 
favoravelmente, mas a presença de características desejáveis como praticidade e rapidez no preparo devem ter contribuido para o aumento do consumo desse produto.

Verificou-se nos ítens anteriores que alguns alimentos básicos do almoço e do jantar dos brasileiros, tais como arroz, feijão, carne bovina, batata inglesa, alface e tomate, apresentaram redução em seu consumo e que o tempo de preparo foi um fator importante nessas mudanças. O ovo, elemento importante dessas refeições, teve comportamento contrário, indicando possuir características desejáveis para o consumidor.

\subsubsection{Açúcares e derivados}

A Tabela 30 apresenta o ajustamento da poligonal log-log aos dados de despesas com açúcares e derivados de dez áreas urbanas ${ }^{6}$ do Brasil fornecidos pela POF. Os valores de $F$ geralmente são elevados e, portanto, significativos os nível de $5 \%$. Em Belém o valor de $F$ é significativo apenas ao nível de $10 \%$.

Em Porto Alegre e Curitiba encontram-se os menores valores do coeficiente de determinação $\left(R^{2}\right)$, 0,65 e 0,78, respectivamente. Nas áreas urbanas restantes, seus valores encontram-se sempre acima de 0,900 , indicando que houve um bom ajustamento da poligonal aos dados.

Os valores do coeficiente de variação $(C V)$ indicam que há boa qualidade nos resultados. Com exceção de Porto Alegre, os valores estão sempre abaixo de 5\%.

As estimativas dos coeficientes de elasticidade-renda em todas as áreas urbanas estudadas são crescentes entre o primeiro e o segundo estrato e, entre o segundo e o terceiro estrato tornam-se decrescentes. Apenas em Belo Horizonte o coeficiente do terceiro estrato é maior do que aquele encontrado no primeiro estrato. No primeiro e

\footnotetext{
${ }^{6}$ Nenhum dos esquemas de agrupamento obtidos para a área urbana de Brasília apresentou resultados satisfatórios. Portanto não foram utilizados
} 
segundo estratos predominam coeficientes positivos e no terceiro estrato observam-se sinais negativos em Curitiba, Rio de Janeiro, Salvador e Belém.

TABELA 30 - Coeficientes de Elasticidade-renda da despesa per capita com açúcares e derivados nos estratos considerados para 10 áreas urbanas do Brasil, obtidos através do ajustamento de uma poligonal log-log de acordo com dados da POF (1987-88).

\begin{tabular}{lccccccccc}
\hline & Esquema de & $R^{2}$ & $C V$ & \multicolumn{2}{c}{ Elasticidade do estrato } & & Elasticidade & Valor \\
Área urbana & agrupamento & & $\%$ & I & II & III & média & de $F$ \\
\hline Goiânia & $3-6-1$ & 0,95 & 2,8 & 0,264 & 0,297 & 0,593 & 0,384 & $37,48^{* *}$ \\
Porto Alegre & $3-3-4$ & 0,65 & 5,9 & 0,054 & 0,859 & 0,052 & 0,314 & $3,78^{*}$ \\
Curitiba & $8-1-1$ & 0,78 & 2,8 & $0,165^{*}$ & 0,974 & $-0,232$ & 0,189 & $6,95^{* *}$ \\
São Paulo & $8-1-1$ & 0,96 & 1,8 & $0,216^{* *}$ & 1,053 & 0,151 & 0,313 & $43,52^{* *}$ \\
Rio de Janeiro & $7-2-1$ & 0,94 & 3,1 & $0,259^{* *}$ & $1,546^{* *}$ & $-0,491^{* *}$ & 0,435 & $30,01^{* *}$ \\
Belo Horizonte & $4-4-2$ & 0,99 & 1,2 & $0,197^{* *}$ & $0,388^{*}$ & $0,611^{*}$ & 0,408 & $165,13^{* *}$ \\
Salvador & $8-1-1$ & 0,98 & 1,4 & $0,094^{* *}$ & $1,984^{* *}$ & $-0,310^{* *}$ & 0,218 & $85,82^{* *}$ \\
Recife & $3-2-5$ & 0,98 & 1,4 & $0,241^{*}$ & 0,580 & $0,212^{*}$ & 0,287 & $99,35^{* *}$ \\
Fortaleza & $6-2-2$ & 0,98 & 1,5 & $0,221^{* *}$ & $0,754^{* *}$ & $0,057^{* *}$ & 0,294 & $99,53^{* *}$ \\
Belém & $3-6-1$ & 0,93 & 2,4 & 0,121 & $0,447^{*}$ & $-0,297^{* *}$ & 0,264 & $24,67^{* *}$ \\
\hline
\end{tabular}

Fonte: Dados da IBGE $(1991, \mathrm{n} .1)$ processados pelo autor.

${ }^{1}$ A elasticidade média geral ponderada para as 10 áreas urbanas é de 0,341 .

No primeiro estrato o teste $t$ refere-se à hipótese de que a elasticidade-renda é igual a zero. No segundo e terceiro estratos, o teste $t$ refere-se à hipótese de que a diferença da elasticidade do estrato em relação à do estrato anterior é igual a zero.

${ }^{* *}$ Significativo ao nível de $5 \%$.

* Significativo ao nivel de $10 \%$.

No Rio de Janeiro, Belo Horizonte, Salvador, Recife, Fortaleza e Belém, as diferenças entre pelo menos dois dos estratos considerados são estatisticamente significativas pelo teste $t$, a um nível de 10\%. Nas demais áreas, as variações não são 
estatisticamente significativas. Apenas em Goiânia, Porto Alegre e Belém os coeficientes do primeiro estrato não diferem estatisticamente de zero.

Os coeficientes de elasticidade-renda da despesa com açúcar para o município de Piracicaba, calculados por Perez (1973), apresentaram comportamento diferente daquele observado neste trabalho. Eles se mostraram decrescentes entre o primeiro e segundo estratos e crescentes entre o segundo e terceiro estratos. Os valores obtidos foram $0,93,0,11$ e 0,28 para o primeiro, segundo e terceiro estratos, respectivamente.

Furtuoso (1981) calculou os coeficientes de elasticidade-renda do dispêndio com açúcares e derivados para o estado de São Paulo com base nos dados do ENDEF. Os coeficientes obtidos para o primeiro, segundo e terceiro estratos foram, respectivamente, $0,43,0,06$ e 0,18

A elasticidade-renda média mostra-se positiva em todas as áreas urbanas estudadas. Rio de Janeiro apresenta o maior coeficiente, 0,435, seguido por Belo Horizonte, 0,408, e Goiânia, 0,384. Já em Curitiba foi encontrado o menor coeficiente de elasticidade média para açúcares e derivados, 0,189. A elasticidade média geral para as dez áreas urbanas é 0,341. Este valor é superior ao valor obtido por Melo (1988) para os anos de 1974/75 para o Brasil como um todo. Utilizando dados fornecidos pelo ENDEF este autor obteve o valor 0,29 para o coeficiente médio da elasticidade-renda do dispêndio com açúcares e derivados.

A Tabela 16 mostra que no período de aproximadamente 12 anos que separa as pesquisas ENDEF e POF, o consumo anual per capita de açúcares e derivados aumentou apenas $1,10 \%$, ou o equivalente a $281 \mathrm{~g}$. Ao mesmo tempo, houve uma elevação nas despesas monetárias com esse grupo de alimentos de $80,50 \%$ (Tabela 17).

De acordo com a Tabela 16, açúcar cristal e refinado, juntos, representavam $96 \%$ do consumo total de açúcares e derivados, em 1974/75. Embora em 1987/88 esse valor tenha se reduzido para $87 \%$, o comportamento do grupo dos açúcares e derivados 
continua sendo essencialmente determinado pelo comportamento do consumo de açúcar cristal e refinado.

A Figura 17 mostra a variação dos preços médios anuais do açúcar no varejo da cidade de São Paulo. Em todo o período os preços mantiveram-se superiores aos de 1974. Os valores registrados em 1988 foram 63\% mais caros do que os de 1974 . E, quando se consideram os períodos específicos nos quais as pesquisas ENDEF e POF foram realizadas, observa-se uma elevação de $52 \%$ nos preços. Com base nesses dados, pode-se afirmar que a evolução dos preços foi desfavorável ao consumo desse grupo de alimentos.

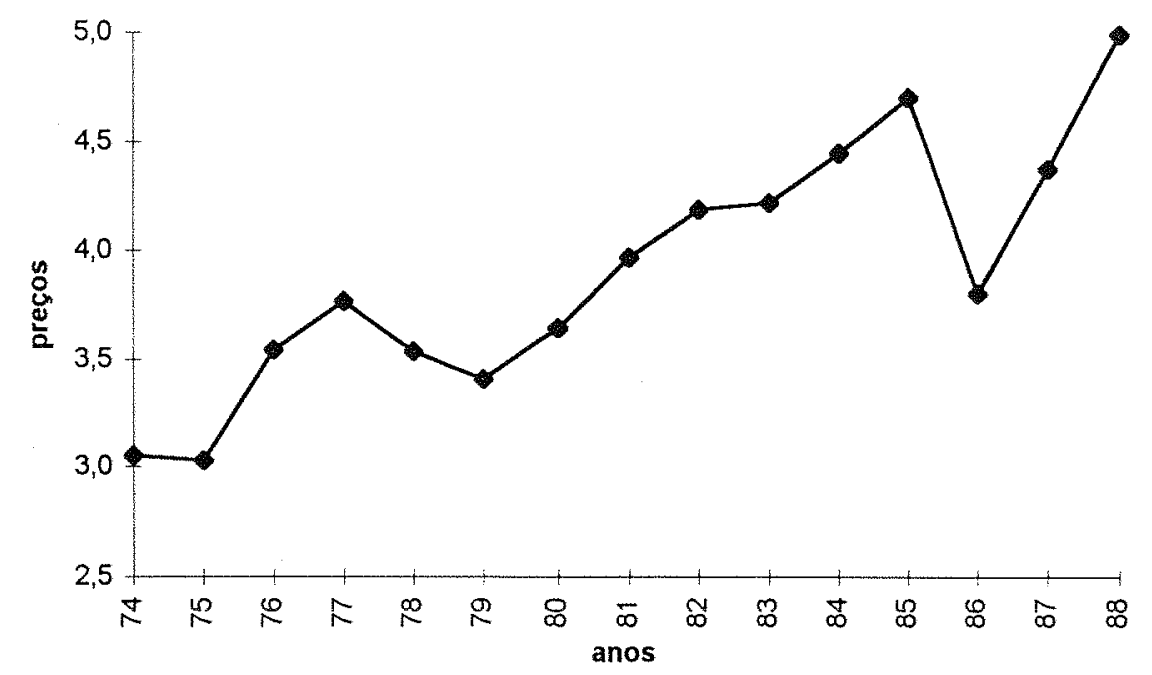

Figura 17 - Preços médios anuais do açúcar (kg) no varejo da cidade de São Paulo 1974/88. Em cruzados de março de 1986.

Fonte: Dados do IEA (1990) processados pelo autor.

Através do coeficiente de elasticidade média geral $(0,341)$ pode-se inferir que o aumento de $32 \%$ no PIB per capita dos brasileiros observado entre os anos de $1974 \mathrm{e}$ 1988 seria capaz de promover uma elevação de 10,91\% em suas despesas com açúcares e derivados, desde que a distribuição da renda tenha se mantido inalterada nesse período.

Tomando-se o consumo físico de açúcar cristal e refinado por comensal apresentado no ENDEF $(24,537 \mathrm{~kg})$ obtém-se, considerando o aumento nas despesas de $10,91 \%$, uma elevação de $2,677 \mathrm{~kg}$ no consumo desse produto. 
Nota-se, também, que apesar do aumento no consumo de açúcares e derivados entre 1974 e 1988 ter sido muito pequeno, o aumento em seu dispêndio foi bastante alto $(80,50 \%)$, devido à elevação nos preços do açúcar.

\subsubsection{Alimentação fora do domicílio}

Nos resultados obtidos por meio do ajustamento das poligonais $\log -\log$ aos dados de despesa com alimentação fora do domicílio encontram-se valores de $F$ bastante elevados, sendo que os mesmos são, em todos os casos, significativos ao nível de $1 \%$ (Tabela 31). Conseqüentemente, os valores exibidos pelo coeficiente de determinação $\left(R^{2}\right)$ estão sempre próximos de 1, com o menor valor igual a 0,94 , para Belo Horizonte.

Os resultados do coeficiente de variação $(C V)$, assim como ocorreu com o coeficiente de determinação $\left(R^{2}\right)$, indicam boa qualidade nos ajustamentos das poligonais aos dados. Seu maior valor não é superior a $5 \%$.

Excluindo Belo Horizonte e Salvador, nas demais áreas urbanas desse estudo os coeficientes de elasticidade-renda são decrescentes. Os coeficientes daquelas duas áreas urbanas mostram-se crescentes entre o primeiro e segundo estratos e decrescentes entre o segundo e terceiro estratos.

Todos os coeficientes do primeiro e segundo estratos são positivos. No terceiro estrato, apenas Belo Horizonte apresentou sinal negativo. Goiânia, Curitiba, São Paulo, Rio de Janeiro e Fortaleza apresentam, no primeiro estrato, coeficientes de elasticidade-renda maiores do que 1 . No segundo estrato também podem-se observar coeficientes com valores maiores do que 1 no Rio de Janeiro, Belo Horizonte e Salvador.

Em Goiânia, Curitiba e Belém as variações são, pelo teste $t$, estatisticamente significativas entre pelo menos dois dos estratos considerados, ao nível de $10 \%$. Nas demais áreas urbanas, as variações entre os estratos são não significativas estatisticamente. Na maior parte das áreas urbanas estudadas os coeficientes do primeiro estrato diferem estatisticamente de zero a um nível de $5 \%$. 
TABELA 31 - Coeficientes de Elasticidade-renda da despesa per capita com alimentação fora do domicílio nos estratos considerados para 11 áreas urbanas do Brasil, obtidos através do ajustamento de uma poligonal log-log de acordo com dados da POF (1987-88).

\begin{tabular}{lccccccccc}
\hline & Esquema de & $R^{2}$ & $C V$ & \multicolumn{2}{c}{ Elasticidade do estrato } & Elasticidade & Valor \\
Área urbana & agrupamento & & $\%$ & I & II & III & média $^{\prime}$ & de $F$ \\
\hline Goiânia & $1-8-1$ & 0,99 & 2,3 & $3,584^{* *}$ & $0,740^{* *}$ & $0,290^{*}$ & 0,596 & $131,76^{* *}$ \\
Brasilia & $5-3-2$ & 0,97 & 3,2 & $0,826^{* *}$ & 0,686 & 0,680 & 0,704 & $59,45^{* *}$ \\
Porto Alegre & $6-3-1$ & 0,99 & 2,1 & $0,871^{* *}$ & 0,835 & 0,746 & 0,818 & $132,57^{* *}$ \\
Curitiba & $4-5-1$ & 0,99 & 2,3 & $1,335^{* *}$ & $0,913^{*}$ & $0,128^{*}$ & 0,723 & $148,54^{* *}$ \\
São Paulo & $1-3-6$ & 0,98 & 2,1 & $2,370^{* *}$ & 0,867 & 0,707 & 0,728 & $114,29^{* *}$ \\
Rio de Janeiro & $1-3-6$ & 0,98 & 2,6 & $2,504^{* *}$ & 1,004 & 0,684 & 0,749 & $102,94^{* *}$ \\
Belo Horizonte & $2-7-1$ & 0,94 & 4,3 & 0,166 & 1,009 & $-0,073$ & 0,698 & $29,75^{* *}$ \\
Salvador & $1-1-8$ & 0,99 & 1,7 & 0,537 & 1,301 & 0,589 & 0,613 & $136,96^{* *}$ \\
Recife & $7-1-2$ & 0,98 & 2,3 & $0,832^{* *}$ & 0,559 & 0,393 & 0,647 & $117,35^{* *}$ \\
Fortaleza & $4-2-4$ & 0,99 & 2,0 & $1,028^{* *}$ & 0,818 & 0,418 & 0,640 & $164,95^{* *}$ \\
Belém & $1-8-1$ & 0,99 & 1,5 & $0,888^{* *}$ & 0,795 & $0,404^{*}$ & 0,675 & $221,39^{* *}$ \\
\hline
\end{tabular}

Fonte: Dados da IBGE (1991, n. 1) processados pelo autor.

1 A elasticidade média geral ponderada para as 11 áreas urbanas é de 0,719.

No primeiro estrato o teste $t$ refere-se à hipótese de que a elasticidade-renda é igual a zero. No segundo e terceiro estratos, o teste $t$ refere-se à hipótese de que a diferença da elasticidade do estrato em relação à do estrato anterior é igual a zero.

** Significativo ao nível de $5 \%$.

* Significativo ao nível de $10 \%$.

Os coeficientes de elasticidade-renda da despesa com alimentação fora do domicílio calculados por Furtuoso (1981) para o estado de São Paulo a partir dos dados do ENDEF apresentaram comportamento diferente do observado neste trabalho. Eles se mostraram crescentes entre o primeiro e segundo estratos, passando de 0,89 para 1,15, e decrescentes entre o segundo e terceiro estratos, atingindo o valor 0,51 . 
A elasticidade-renda média mostra-se positiva em todas as áreas urbanas estudadas. Seu valor oscila entre 0,500 e 0,700 em Goiânia, Belo Horizonte, Salvador, Recife, Fortaleza e Belém e entre 0,700 e 0,900 em Brasilia, Porto Alegre, Curitiba, São Paulo e Rio de Janeiro.

O valor médio anual das despesas monetárias per capita com alimentação fora do domicílio mais que dobrou entre 1974/75 e 1987/88, passando de Cz $\$ 511,28$ para $\mathrm{Cz} \$$ $1.066,55$.

A elasticidade média geral com alimentação fora do domicilio, ponderada para as onze áreas urbanas, é de 0,719 e, considerando o aumento de $32 \%$ no PIB per capita, projeta-se um aumento nessas despesas de $23 \%$, desde que seja mantida constante a distribuição da renda.

Como as pesquisas ENDEF e POF não especificam o tipo de alimento consumido fora do lar bem como as suas quantidades, torna-se impossivel determinar a influência dos preços nesse tipo de despesas. Sabe-se, porém, que o efeito da mudança dos hábitos alimentares é cada vez mais importante para esse tipo de despesa, em função do aumento do custo de oportunidade dos indivíduos, bem como pela possibilidade de realocar em lazer o tempo exigido para que as refeições sejam feitas no domicílio. Pois o ato de "comer fora" está, muitas vezes, diretamente associado à lazer. 


\section{CONCLUSÕES}

$O$ intenso processo de urbanização e a rápida industrialização que presenciamos nas últimas décadas trouxeram mudanças significativas no cotidiano dos brasileiros. As transformações sociais e tecnológicas associadas a esses processos possibilitaram que o estilo de vida urbano, baseado na satisfação das necessidades pessoais através da compra de bens e serviços, se estabelecesse definitivamente em todo o pais.

Ao migrar para os centros urbanos os antigos hábitos dos indivíduos foram transformados ou substituídos. Os novos moradores das cidades, que até então podiam produzir grande parte dos alimentos que consumiam, passaram a adquiri-los no comércio local. A dieta básica dos brasileiros, resultado da mistura de hábitos indígenas, africanos e europeus e restrita pela capacidade natural que as diversas regiões tinham em produzir diferentes alimentos, passa a sofrer interferência do padrão urbano de consumo, com destaque para os produtos industrializados divulgados amplamente pelos meios de comunicação.

A vida quotidiana nos aglomerados urbanos possui uma dinâmica própria, o que determina parcialmente o comportamento dos seus moradores e interfere diretamente nos seus hábitos alimentares. Esse comportamento é determinado pelo ritmo acelerado das atividades, pelas crescentes distâncias entre a casa e o trabalho, pelo efeito marcante das propagandas, pelo estilo de vida sedentário, pelo aumento do trabalho feminino fora do lar, pela maior demanda por lazer etc. 
Tendo esta situação como pano de fundo pôde-se constatar, através do desenvolvimento deste estudo, que entre os anos de 1974/75 e 1987/88 a dieta dos brasileiros se alterou consideravelmente. Observou-se uma elevação de $15,13 \mathrm{~kg}$ no consumo per capita médio anual do conjunto de alimentos analisado, embora o total das despesas com esses produtos tenha se reduzido em $5 \%$.

$\mathrm{O}$ consumo de cereais diminuiu, enquanto o de alimentos mais ricos nutricionalmente aumentou sensivelmente. Outra característica peculiar dos alimentos substitutos está na praticidade e rapidez de preparo, indicando que a economia de tempo também norteou as mudanças ocorridas no padrão alimentar. As despesas com alimentação fora do lar mais que dobraram, passando a representar $25 \%$ do total das despesas com alimentação, o que reforça a importância da utilização do tempo nas mudanças ocorridas.

A dieta do brasileiro, composta tradicionalmente por um pequeno desjejum, pelo almoço, que é refeição principal, e pelo jantar, sofreu modificações. O leite, alimento ingerido normalmente no café da manhã, foi o produto que teve o maior aumento no seu consumo médio per capita durante o período compreendido por este estudo. Os preços médios do leite, principalmente do tipo $\mathrm{C}$, não se comportaram de forma a favorecer o aumento no seu consumo e o efeito da renda explica apenas pequena parte dessa variação. Estes resultados mostram que essa mudança alimentar se deve a outros fatores relacionados ao consumo deste produto. A versatilidade no uso, a facilidade de preparo e a superioridade em termos nutricionais são os principais atrativos do leite, e certamente estão favorecendo o aumento em seu consumo.

Componentes básicos do almoço e do jantar tradicional, o arroz e o feijão tiveram seu consumo médio per capita reduzido. A redução no consumo desses dois produtos não coincide com o efeito projetado pela renda e também não é explicado pela variação nos preços. Outros alimentos importantes que, geralmente, acompanham essas refeições, como a carne bovina, a batata-inglesa que é consumida frita ou cozida, o alface 
e o tomate que estão presentes na salada, também tiverem seu consumo reduzido. As variações observadas no consumo desses alimentos mostram que as mudanças nos hábitos alimentares estão caminhando no sentido de substituir os alimentos característicos das refeições tradicionais por alimentos que exigem menor tempo de preparo e que possuem elevado valor nutritivo ou mesmo pelo aumento da alimentação realizada fora do domicilio.

A ingestão de carne bovina continua sendo superior à de carne suína e a de frango, porém o seu nível médio de consumo per capita apresentou uma pequena redução. Entre os três principais tipos de carne, a suína ainda é a menos consumida pelos brasileiros, e a elevação observada no seu consumo médio foi pequena. O melhor desempenho entre as carnes foi observado na carne de frango, que apresentou um aumento de $60 \%$ em seu consumo.

Dentre as carnes estudadas a bovina apresentou o maior coeficiente de elasticidade-renda média e, ao contrário do que foi projetado pelo efeito renda, o seu consumo se reduziu. Enquanto os preços das carnes de frango e suína se reduziram em mais de $20 \%$, o preço da carne bovina manteve-se muito próximo do valor de 1974 , desestimulando o seu consumo. O crescimento da renda per capita fazia prever um aumento no consumo de carne suína maior do que o observado. Para a carne de frango o efeito da renda projetou um aumento no consumo substancialmente menor do que o observado. Isto mostra que além do efeito favorável dos preços e da renda, o consumo frango foi favorecido pela substituição do consumo de outras carnes.

Um dos poucos componentes básicos do almoço e do jantar dos brasileiros que não apresentou redução em seu consumo foi o ovo. A elevação na renda responde por boa parte do aumento observado no seu consumo e os preços observados no período também contribuíram favoravelmente, mas a presença de características desejáveis como praticidade e rapidez no preparo certamente tiveram grande importância no aumento do consumo desse produto. 
Como o efeito da renda explica somente metade da variação observada no consumo de frutas e os preços dos produtos presentes neste item, de forma geral, não se comportaram favoravelmente ao aumento em seu consumo, considera-se que parte da elevação observada no consumo de frutas se deve a outras características desses alimentos. Nesse sentido pode-se destacar a facilidade de preparo, pois muitas frutas são consumidas in natura, e o fato de apresentarem boas características nutricionais, com elevados teores de vitaminas e fibras. A banana e a laranja continuam sendo as frutas mais consumidas pelos brasileiros, embora as variações em seu consumo tenham sido pequenas. Isto mostra que o aumento observado no consumo deste item está associado ao consumo de outras frutas

$\mathrm{O}$ item óleos e gorduras apresentou elevação, embora pequena, em seu consumo. Esta variação foi substancialmente menor do que o efeito projetado pela renda. De forma geral os preços se mantiveram favoráveis ao aumento no consumo. $\mathrm{O}$ preço médio do óleo de soja, principal produto deste item, se reduziu em cerca de $15 \%$ no período analisado. Como o aumento observado nesse grupo de alimentos foi menor do que o efeito da renda e dos preços possibilitaria, considera-se que o comportamento dos consumidores em relação a esses alimentos está mudando. A diminuição no consumo de outros alimentos básicos como arroz e feijão influenciam diretamente o consumo de óleos, pois são utilizados em seu cozimento. Certamente a preocupação com a saúde e os problemas decorrentes do uso excessivo de óleos e gorduras estão afetando, cada vez mais, o consumo desses produtos.

O consumo de açúcar (cristal e refinado) se reduziu em mais de $2 \mathrm{~kg}$, embora o consumo de outros tipos de açúcares ou de seus derivados tenha se elevado quase que na mesma quantidade. Isto fez com que o grupo dos açúcares e derivados apresentasse apenas uma pequena elevação em seu consumo. $O$ efeito da renda projetou uma elevação muitas vezes maior no consumo desses alimentos do que de fato se observou. $O$ fato de os preços do açúcar terem se elevado em mais de $50 \%$ no período analisado certamente afetou o consumo desses alimentos. 
De forma geral os coeficientes médios de elasticidade-renda do dispêndio obtidos nesta pesquisa apresentaram valores menores do que 1 . Os coeficientes de elasticidade-renda se mostraram decrescentes com o aumento da renda per capita no estrato para os seguintes produtos: arroz, feijão, carnes bovina, suína e de frango e para as despesas com alimentação fora do domicílio.

Como os coeficientes de elasticidade-renda obtidos são pequenos e atingem seus maiores valores nas classes de mais baixa renda, o efeito de uma eventual elevação na renda sobre o consumo desses alimentos, sem que haja uma redistribuição dessa renda, será pequeno. No ano de 1996, por exemplo, $70 \%$ da população mais pobre ficava com apenas $25,7 \%$ do total de recebimentos mensais e, nesse caso, se ocorresse um aumento de $10 \%$ na renda, sem que a sua distribuição fosse alterada, os $30 \%$ mais ricos seriam beneficiados com a grande massa desse aumento ( $74,3 \%$ do aumento), enquanto a renda restante $(25,7 \%)$, seria dividida entre os $70 \%$ mais pobres. 


\section{REFERÊNCIAS BIBLIOGRÁFICAS}

ACKLEY. G. Teoria macroeconômica. São Paulo: Pioneira, 1969. v. 1, 326p.

ANUÁRIO ESTATÍSTICO DO BRASIL - 1996, v.56, p. 2-14, 1997.

AVES \& OVOS. Mercado. v.9, n.3, p.10, jan. 1993.

CONJUNTURA ECONÔMICA. Conjuntura Estatística. v. 52, n. 1, p. 18, jan. 1998.

COMISSÃO DE FINANCIAMENTO DA PRODUÇÃO. Estudo do consumo de alimentos básicos no Brasil: resumo e conclusões finais. Brasilia: Secretaria do Planejamento, 1981, 95p.

BACCHI, M. R. P. Demanda de carne bovina no mercado brasileiro. Piracicaba, 1989. 80p. Dissertação (Mestrado) - Escola Superior de Agricultura "Luiz de Queiroz", Universidade de São Paulo.

FARIA, M. C. de Hábitos de consumo de alimentos da população urbana de ViçosaMG: $1983 / 84$ e 1991/92. Viçosa, 1997. 106p. Dissertação (Mestrado) Universidade Federal de Viçosa.

FURTUOSO, M. C. O. Redistribuição de renda e consumo de alimentos no estado de São Paulo. Piracicaba, 1981. 106p. Dissertação (Mestrado) - Escola Superior de Agricultura "Luiz de Queiroz", Universidade de São Paulo.

HOFFMANN, R. Variação estacional dos preços de produtos agrícolas no estado de São Paulo. Piracicaba, ESALQ,1970. 133p.

HOFFMANN, R. Elasticidades de Engel para dispêndios familiares na cidade do Rio de Janeiro: outro método de estimação. Pesquisa e Planejamento Econômico, v.13, n. 1, p. 267-274, abr. 1993

HOFFMANN, R. Pobreza, insegurança alimentar e desnutrição no Brasil. Estudos Avançados, v.9, n.24, p.159-172, 1995a. 
HOFFMANN, R. A diminuição do consumo de feijão no Brasil. Estudos Econômicos, v.25, n.2, p.189-201, maio/ago. 1995b.

HOFFMANN, R.; FURTUOSO, M. C. O. Determinação da elasticidade-renda da demanda de alimentos no Estado de São Paulo através o ajustamento de uma poligonal. In: ENCONTRO BRASILEIRO DE ECONOMETRIA, 3., Olinda, 1881. Anais. Brasília: Sociedade Brasileira de econometria, 1981. p.455-471.

HOFFMANN, R.; SCAMPINI, P.J. O consumo de leite. Preços Agrícolas, ano 10, n. 144, p 4-5, 1996.

INSTITUTO BRASILEIRO DE GEOGRAFIA E ESTATÍSTICA. Estudo nacional da despesa familiar: despesas das famílias. Rio de Janeiro, 1978a.

INSTITUTO BRASILEIRO DE GEOGRAFIA E ESTATÍSTICA. Estudo nacional da despesa familiar: consumo alimentar antropometria. Rio de Janeiro, $1978 \mathrm{~b}$.

INSTITUTO BRASILEIRO DE GEOGRAFIA E ESTATÍSTICA. Estatísticas históricas do Brasil: séries econômicas, demográficas e sociais de 1950 a 1988. 2.ed. Rio de Janeiro, 1990.

INSTITUTO BRASILEIRO DE GEOGRAFIA E ESTATÍSTICA. Pesquisa de orçamentos familiares - 1987/88. Rio de Janeiro, 1991. n. 1, 564p.

INSTITUTO BRASILEIRO DE GEOGRAFIA E ESTATÍSTICA. Pesquisa de orçamentos familiares $\mathbf{- 1 9 8 7 / 8 8}$. Rio de Janeiro, 1991. n.2, 71p.

INSTITUTO BRASILEIRO DE GEOGRAFIA E ESTATÍSTICA. Pesquisa de orçamentos familiares - 1995/96: primeiros resultados. Rio de Janeiro, 1997a. 247p.

INSTITUTO BRASILEIRO DE GEOGRAFIA E ESTATÍSTICA. Pesquisa nacional por amostra de domicílios - 1996. Síntese de indicadores. Rio de Janeiro: IBGE. $1997 b$. 
INSTITUTO DE ECONOMIA AGRÍCOLA. São Paulo, Estatística de preços agrícolas no estado de São Paulo. Tomo 2: Preços no atacado e varejo, 1990.

JUNQUEIRA, A. H. O. Plano real e os seus reflexos sobre a produção e o consumo de alimentos no Brasil. Conjuntura Alimentos, v.7, n. 1, p.4-11, jan-abril 1995.

MALUF, R. S. J. O encarecimento dos alimentos no Brasil. Conjuntura Alimentos, v.4, n.1, p.28-30, maio 1992.

MELO, F. H. de Um diagnóstico sobre produção e abastecimento alimentar no Brasil. In: SEMINÁRIO INTERNACIONAL DE POLÍTICA AGRÍCOLA, São Paulo, 1988. $123 \mathrm{p}$

MELO, F. H. de Tendência de queda dos preços reais de insumos agrícolas. Revista de Economia Política, v.45, p.141-146, 1992.

MILLER, R. L. Microeconomia: teoria, questões e aplicações. São Paulo: Mc GrawHill do Brasil, 1981. 507p

MONTEIRO, C. A. A dimensão da pobreza, da fome e da desnutrição no Brasil. Estudos Avançados, v.9, n.24, p195-207, mai-ago 1995.

OLIVEIRA, S. P. de.; THÉBAUD-MONY, A. Modelos de consumo agro-industrial: homogeneização ou diversificação dos hábitos alimentares. Cadernos de Debate, v.4, p.1-13, 1996.

PEREZ, M. C. R. C. Contribuição ao estudo da elasticidade-renda do consumo de alimentos. Piracicaba, 1973. 94p. Dissertação (Mestrado) - Escola Superior de Agricultura "Luiz de Queiroz", Universidade de São Paulo.

PINAZZA, L. A.; ARAUJO, N. B. Agricultura na virada do século XX: visão do agribusiness. São Paulo: Globo S.A., 1993. 166p. 
REZENDE, P. S. Matriz de elasticidades da procura e projeção de consumo de produtos agrícolas, em Juiz de Fora - Minas Gerais. Viçosa, 1974. 101p. Dissertação (Mestrado) - Universidade Federal de Viçosa.

SENAUER, B.; ASP, E.; KINSEY, J. Food trends and the changing consumer. St. Paul: Eagan Press, 1993. 385p.

SILVA, A. C. da De Varga a Itamar: políticas e programas de alimentação e nutrição Estudos Avançados, v. 9, n.23, p.87-107, 1995.

SILVA, J. G. da Distribuição da renda, preços dos alimentos e padrão de desenvolvimento agrícola. Conjuntura Alimentos. v. 5, n 2 , p38-44, junho. 1993.

SILVA, L. F.; FABRINI FILHO, L. C. Complexo Avícola e questões sobre hábitos alimentares. Cadernos de Debate, ano II, n.2, p.41-61, 1994.

SIMON, E. J. O consumo de alimentos em Botucatu, S.P. Piracicaba, 1981. 130p. Dissertação (Mestrado) - Escola Superior de Agricultura "Luiz de Queiroz", Universidade de São Paulo.

TASCO, A. M. P.; MENEGÁRIO, R. S. Consumo de frutas. São Paulo. Conjuntura Alimentos, v.4, n.4, p. 22-27, dezembro de 1992.

VEIGA, J.E. da A inflação da sopa. Informações Fipe, n.120,. p.9-10, jul 1990.

VEIGA, J.E da Alimentação e custo de vida. Informações Fipe, n.160, p.23-26, jan. 1994. 